\title{
Het werk van de huisarts : resultaten van een functie- analyse in 93 huisartspraktijken
}

Citation for published version (APA):

Boots, J. M. M. (1983). Het werk van de huisarts : resultaten van een functie-analyse in 93 huisartspraktijken. [Doctoral Thesis, Maastricht University]. Rijksuniversiteit Limburg. https://doi.org/10.26481/dis.19830617jb

Document status and date:

Published: 01/01/1983

DOI:

10.26481/dis.19830617jb

Document Version:

Publisher's PDF, also known as Version of record

\section{Please check the document version of this publication:}

- A submitted manuscript is the version of the article upon submission and before peer-review. There can be important differences between the submitted version and the official published version of record.

People interested in the research are advised to contact the author for the final version of the publication, or visit the DOI to the publisher's website.

- The final author version and the galley proof are versions of the publication after peer review.

- The final published version features the final layout of the paper including the volume, issue and page numbers.

Link to publication

\footnotetext{
General rights rights.

- You may freely distribute the URL identifying the publication in the public portal. please follow below link for the End User Agreement:

www.umlib.nl/taverne-license

Take down policy

If you believe that this document breaches copyright please contact us at:

repository@maastrichtuniversity.nl

providing details and we will investigate your claim.
}

Copyright and moral rights for the publications made accessible in the public portal are retained by the authors and/or other copyright owners and it is a condition of accessing publications that users recognise and abide by the legal requirements associated with these

- Users may download and print one copy of any publication from the public portal for the purpose of private study or research.

- You may not further distribute the material or use it for any profit-making activity or commercial gain

If the publication is distributed under the terms of Article $25 \mathrm{fa}$ of the Dutch Copyright Act, indicated by the "Taverne" license above, 
HET WERK VAN DE HUISARTS

Resultaten van een functie-analyse in 93 huisartspraktijken

\section{PROEFSCHRIFT}

ter verkrijging van de graad van doctor in de geneeskunde aan de Rijksuniversiteit Limburg te Maastricht op gezag van de Rector Magnificus Prof. Dr. H.C. Hemker, volgens besluit van het College der Dekanen in het openbaar te verdedigen op vrijdag 17 juni 1983 des namiddags om vier uur precies, in de aula van de universiteit,

\section{door}

Johannes Maxtinus Joseph Boots geboren te Ven1o in 1942 
Promotores: Prof. Dr. H. Philipsen Prof. Dr. W. Brouwer

Referenten: Prof. Dr. F.F.H. Rutten Prof. Dr. G.J. Bremer

Manuscript: A. Simon; M. Keulen

Lay-out : ir. I. Moerman

Druk : B. Meerstad 


\section{Voorwoord}

1. Inleiding

1.1. Maatschappelijke context van het onderzoek

1.2 .

1.3 . Directe aanleiding tot het onderzoek Samenvatting

2.

Probleemstelling en literatuur bij functiebeschri jving

2.1. Probleemstelling

2.2. Probleemstelling en 1iteratuur bij functiebeschrijving

2.2.1. Huisartsen over hun beroep

2.2.2. Het huisartsenberoep als professie

$2 \cdot 2 \cdot 3$. Outputmeting

2.2.4. Empirisch onderzoek naar praktijkuitoefening

$2 \cdot 2 \cdot 4.1$. Het werk van de huisarts

2.2.4.2. Delen uit het werk van de huisarts

2.2.4.3. De vorm van de huisartsenpraktijk

Probleemstelling en literatuur bij verklaring

van verschillen in functie-uitoefening

2.3.1. Vraag en aanbod

2.3.2. Verwijscijfers

3.

Operationalisering

3.1 .

Functies van huisartsen

3.2 .

Taakopvatting

3.3 .

Structuurkenmerken van de gezondheidszorg

3.4 .

Demografische kenmerken

4.

Onderzoeksopzet

4.1.

Methode

4.2 .

Wijze van gegevensverzameling

4.3 .

Meetniveau

4.4 .

Meetinstrumenten

$4 \cdot 4 \cdot 1$

Observatiecategorieën

4.4 .2

Taakperceptie-meting

4.5 .

Steekproeven

4.5 .1 .

"Kleine" steekproef

4.5 .2 .

"Grote" steekproef 
Beschrijving van onderzoeksresultaten

5.1. Tijdbesteding naar functies

5.3. Opvattingen ten aanzien van de hulsartsentaken

5.3.2. Taakopvattingen

5.4. Variabelen in de analyse

6.

Verklaring van verschillen in functie-uitoefening

6.1. Inleiding

6.2 . Analysemodel

6.3 . Resultaten

6.3.1. Eerste specificatie: Betekenis van gemiddeld patiëntenaanbod, praktijkervaring en taakopvatting

6.3.2. Tweede specificatie: Betekenis van structuurkenmerken voor het gemiddeld patiëntenaanbod

6.3.3. Derde specificatie: Betekenis van structuurkenmerken voor de verschillen in taakopvatting

6.3.4. Samengevoegde specificaties

6.4 .

Conclustes

Betekenis van de taakopvatting nader onderzocht Inleiding 
Dit proefschrift is gebaseerd op een onderzoek in 93 huisartspraktijken, uitgevoerd met behulp van 8 arts-observatoren, verspreid over 8 regio's in Nederland. De voorbereiding en uitvoering van een dergelijk onderzoek vraagt de medewerking van velen.

De observaties konden worden uitgevoerd op een dermate omvangrijke schaal dankzif de speciale apparatuur die hiervoor werd ontwikkeld door Hans Koper, verbonden aan de Instrumentele Dienst en de computerprogramma's geschreven door

M. Janssen, lid van Dienst Informatleverwerking aan de Rijksuniversiteit Limburg. De huisartsen in het onderzoek werden op een betrouwbare en volhoudende manfer geobserveerd door de artsen: M. de Reeper, E. van Vroonhoven, M. Smallenburg, K. van Vucht, B. Gotink, W. Boesten, $P$. de Haan en J. Valeton.

De toegang tot het onderzoek werd mogelijk door de grote bekendheld die P.A. de Klerck bezit in de Landelifke Huisartsenvereniging en die hif wilde benutten voor de contacten met het benodigde aantal huisartsen dat aan het onderzoek wilde deelnemen.

De begeleiding gedurende de inhoudelijke voorbereiding werd namens het Med 1 sch Reglonal Centrum in Maastrlcht verzorgd door de huisartsen J. Meljers en A. Haas. De uitgebrelde werkzaamheden ter voorberelding en uitvoering van de schriftelijke enquête bij 614 Nederlandse hulsartsen werden verricht door J. Reiners, die gedurende ruim én jaar aan het onderzoeksproject heeft meegewerkt.

De administratieve ondersteuning was gedurende het gehele project in vertrouwde handen van mevr. M. Doyle.

Aan al deze personen ben ik dankbaarheid verschuldigd, in het besef zeker niet in staat te zijn leders bifdrage hiermede voldoende te belfchten. 
Bijzondere dank wil ik richten aan Wim van Zutphen die als medeverantwoordelijke voor het onderzoek vele momenten van benauwheid, verwarring en opluchting met mij heeft moeten en w1len delen.

Mijn promotor prof. dr. H. Philipsen ben ik erkentelijk voor de wijze waarop $h i j$ mijn behoefte aan vrijheid van de onontbeerlifke gebondenheld heeft voorzlen op die momenten warop het vervolg op de ingeslagen weg voor mij een labyrinth leek.

Met hun kritlsche opmerkingen hebben prof. dr. W. Brouwer en de referenten leder op hun eigen wijze bijgedragen aan de vorm en inhoud die het verslag ten slotte heeft gekregen. Voor de precisle warmee de dames Annie Simon en Monique Keulen tenslotte de eindtekst hebben verzorgd ben ik hen zeer verplicht.

Ook de bijzonder nauwkeurige wijze warmee de correctie van de elndtekst en de lay-out werden uftgevoerd door de heer I. Moerman verdient mijn dankbaarheid.

Alle niet vermelde maar mif bekende personen die op enigerlel wijze hebben bijgedragen aan de totstandkoming van dit proefschrift, kunnen eveneens van mijn erkentelijkheid hiervoor verzekerd zijn. 
HOOFDSTUK 1

INLE IDING

1.1. MAATSCHAPPELIJKE CONTEXT VAN HET ONDERZOEK

Er is een belangrijk onderscheid tussen de rol, die de huisarts vervult in de huidige structur van de Nederlandse Gezondheidszorg, en die van alle andere specialisaties in de medische beroepsuitoefening.

Historisch bezien, kan de ontwikkeling van de huidige diversiteit aan specialisaties in het artsenberoep teruggevoerd worden op de 'geneesmeesters' in de wetgeving van 1865. Aan deze geneesmeesters werd de uitoefening van de geneeskunst toevertrouwd, zonder enige beperking. In de periode 1900 tot 1945 wordt - mede onder invloed van de in 1849 opgerichte "Maatschappij ter bevordering van de Geneeskunst" - een onderscheid zichtbaar in specialisten enzerzijds en alle andere artsen anderzijds. In de periode 1945-1975 vindt een verdere profilering van het huisartsenberoep plaats op zodanige wijze dat alle kenmerken van een professie aan de huisartsen kunnen worden toegeschreven, (Van der Krogt, 1981; Klinkert, 1978).

Een andere belangrijke ontwikkeling, deels in nauwe relatie met de ontstaansgeschiedenis van de huisartsenprofessie, is de bemoelenis van de overheid met de gezondheldszorg. Tot en met de zestiger jaren zou men kunnen spreken van een liberale, passieve rol van de overheid. Alleen onder druk van belangengroepen en bij problemen van openbare hygiëne of sociaal ontoelaatbare achterstelling van bevolkingsgroepen, trad de wetgever regulerend op. De regering bemiddelde wel in conflicten tussen bijwoorbeeld verzekeraars en artsen, of creëerde mogelijkheden voor opleiding, maar het particuliere initiatief, verzuild naar geloofsovertuiging of naar maatschapppelijke of economische belangen, was oppermachtig, (Festen, 1974; Juffermans, 1977). 
Met het uitbrengen van de volksgezondheidsnota door het ministerle van Soclale Zaken en Volksgezondheid in 1966 wordt een eerste stap gezet in de richting van een meer actief, gerlcht beleid vanuit de centrale overheid. In deze nota wordt een beeld geschetst van de totale gezondheidszorg in Nederland op dat moment, waardoor pas goed de later nog valk beschreven versnipperde structur zichtbaar wordt.

Met de totstandkoming van het nieuwe departement "Volksgezondheid en Milleuhyglëne" in 1970, wordt de overheidstaak in de gezondheldszorg duidelijker gericht op actieve participatie en elgen initiërende verantwoordelijkheid. De "Structuurnota Gezondheidszorg" in 1974 onder staatssecretaris Hendriks van Volksgezondheid uitgebracht, geeft voor het eerst een min of meer logisch gestructureerd schema van de totale gezondheidszorg. Hieraan gekoppeld worden beleidsvoornemens beschreven, die door de gerichte aanpak op centraal niveau moeten leiden tot een beter beheersbare, stuurbare gezondheldszorg. Belangrijk in dit verband, is de duidelijk uitgesproken intentie on de geconstateerde hoofdaccenten - die in de gezondheidszorg vallen op ziekenhuizen en specialistengeneeskunde - te gaan afzwakken en om te buigen in de richting van algemene en eerstelijnsgezondheidszorg. De voor deze operatie noodzakelijke "versterking van de eerste $11 j n^{\prime \prime}$ zal nog jarenlang discussies gaande houden over de meest gewenste, effectieve en zinvolle wijze waarop dit voornemen gestalte kan krijgen. Systeemgerichte onderzoekingen in opdracht van en gefinanclerd door het verantwoordelijke departement, ondersteunden de gedachte dat een verschuiving in het systeem van de gezondheidszorg mogelifk was van tweede naar eerste echelon, zonder dat de kwallteit van de zorg in gevalar gebracht hoeft te worden, (Structurnota 1974). En in dat eerste echelon was de hulsarts, ondanks utgebreide defintties en omslachtige pleidooien, toch de meest duldelijk herkenbare beroepsbeoefenaar. Het gelijktijdig beklemtonen van de elgen kenmerken en verantwoordelijkheden van huisartsen en huisartsgeneeskunde, zowel vanuit de inmiddels "geslaagde" professie, als vanuit de overheldsaandacht voor herstructurering, had een aantal gevolgen, (de Wolff, 1978). 
Allereerst is te noemen de zeer snel groeiende aandacht voor noodzakelijk geachte samenwerking in het eerste echelon. De overheid moest, weliswaar in het haar eigen ambtelijke tempo, de gepropageerde samenwerking van "werkers" in het eerste echelon gaan ondersteunen.

Er werden experimenten opgezet, warbij door departementale ambtenaren initiatieven werden genomen of overgenomen, om huisartsen, matschappelijk werkers of wi jkverpleegkundigen in één samenwerkingsverband onder te brengen, (De Boom en Van Duin, 1973).

Regelingen en overleggroepen gericht op realisering van de als noodzakelijk beschouwde integratie in het eerste echelon, volgden elkaar in snel tempo op.

Met enige overdrijuing kan gezegd worden dat in de jaren 1974-1979 geen congres, workshop of conferentie op het gebied van de gezondheidszorg gehouden kon worden, zonder dat de huisarts en/of het eerste echelon op een of andere manier aan de orde gesteld werd.

Een ander gevolg was de hernfeuwde aandacht die door de huisartsen zelf werd geschonken an de taakomschrijving van het huisartsenberoep. Het "Woudschoten rapport" (1958) kwam weer ter tafel. Zowel het Nederlands Huisartsen Genootschap (N.H.G.), de Koninklijke-Nederlandse Maatschappij ter bevordering van de Geneeskunst (K.N.M.G.), als de Landelijke Huisartsen Vereniging (L.H.V.), stelden studiecomissies samen die het takenpakket van de huisarts in kaart moesten brengen, (L.H.V., 1975; K.N.M.G., 1976; N.H.G., 1978). De resultaten van deze studies verschenen in rapportvorm en vormden onderwerp van discussie in velerlei verbanden. Reacties verschenen in de artsenbladen, waarin tevens velen poogden hun eigen overpeinzingen toe te voegen aan de reeds bestaande beschouwingen. Want ondanks de inspanning, bleven alle rapporten steken in de fase van: opiniërend discussiemateriaal. De L.H.V. doet met haar rapporten "Blauwdruk" (1975) en "De taken van de huisarts" (1977) intensieve pogingen om een min of meer officieel stuk te produceren, waaraan tenminste het merendeel van har leden serieuze gevolgtrekkingen wil verbinden. Grote onenigheid in de ledenvergaderingen nopen het bestuur af te zien van het toekennen van enige offliciële status aan deze rapporten. Eenzelfde lot treft tenslotte de in 1977 verschenen "Nieuwe Blauwdruk". 
Een gevolg van de sterk toegenomen belangstelling die in de zeventiger jaren op de huisarts werd gericht, is de groeiende interesse van onderzoekers voor het huisartsenberoep en de huisartsgeneeskunde. Niet alleen vanuit de huisartsen zelf neent de groep onderzoekers van het eerste echelon toe, ook sociologen, economen, econometristen en andere sociale wetenschappers richten hum aandacht op dit gebied.

Men zou deze studies grofweg in een drietal gebieden kunnen indelen:

a) gericht op probleem- en klachtinventarisatie; merendeels huisartsen zijn hierin geinteresseerd en verbinden hieraan valk voorstellen voor systematische en permanente registratie, (Lamberts, 1977, 1980; 0llemans en Van de Ven, 1975);

b) gerlcht op de besliskundige strategieën in het huisartsenwerk; in deze groep bevinden zich vele sociologen, psychologen, vaak verbonden aan universitaire huisartsinstituten, (N.H.I., 1980, 13-15; De Vries-Robbé, 1978);

c) gericht op kwantitatieve analyse van outputgegevens uit het eerste echelon. In het bijzonder economen en econometristen kiezen voor deze benadering, warbij aan het becijferen van het juiste verwijscijfer en de hiervoor mogelijk te vinden verklarende variabelen vele modellen, methodisch-technische discussies en gedetailleerde analyses van met name zlekenfondsgegevens worden besteed, (Posthuma en Van der Zee, 1977, 1978; Rutten, 1978; Kruldenler, 1977).

Tegen de hierboven geschetste achtergrond moet het ontstaan van dit onderzoek worden gezien.

\subsection{DIRECTE AANLEIDING TOT HET ONDERZOEK}

In 1975 ontstond, mede onder invloed van de hierboven beschreven ontwikkelingen, de overtuiging dat in de Nederlandse gezondheldszorg weliswaar veel beschouwingen gewijd werden aan de centrale plaats van de huisarts, maar dat onder- 
zoekgegevens over zijn feitelijk werk nagenoeg ontbraken. Bovendien groeide in mijn toenmalige werkkring: het ministerie van Volksgezondheid en Milieuhygiëne, de behoefte aan een kwantitatieve, inhoudelijke argumentatie op grond warvan toekomstige aantallen benodigde (huis-) artsen konden worden berekend.

De in het buitenland gehanteerde manpower-planning ging, voorzover empirische benaderingen werden gevolgd, uit van produktiefuncties, (Hiesland, 1966; Reinhardt, 1972, 1973). Hieraan ten grondslag ligt de gedachte dat ten behoeve van een juiste onderlinge afstemming op de vraag naar de gezondheidszorg, het aanbod in zijn kwantitatleve omvang moest worden berekend. In Nederland verkeerden deze manpowervraagstukken nog in het stadium van in- en doorstroom-berekeningen van de medische opleidingen, gerelateerd aan een veelal politiek-economisch bepalde ratio voor (huis-)artsendichtheid, (Thung en De Gruil-Van Egmond, 1978; Commissie Artsenbehoefte, 1964).

Wat betreft de huisartsendichtheid spitste deze discussie zich toe op de regelmatig uitgevoerde bijstellingen van de normpraktijk. De hieraan verbonden consequenties betroffen niet alleen de hoogte van de numerus fixus, maar zeker ook de discussies rond de vraagstukken van vrije vestiging voor huisartsen en hun honorering. Het ontbreken van empirisch verzamelde produktiecijfers was dan veelal reden tot het voeren van ideologisch getinte argumentaties, gebaseerd op meer of minder duidelijk uitgesproken veronderstelingen. Uit discussies in de interdepartementale commissie van de Ministeries Onderwijs en Wetenschappen, en Volksgezondheid en Milieuhygiëne, betreffende de behoefte aan mankracht in de gezondheidszorg, werd duidelijk dat cijfermatige gegevens omtrent feitelijk uitgeoefende werkzaamheden van vrijwel alle beroepsbeoefenaren in de Nederlandse gezondheldszorg, niet of zeer gebrekkig aanwezig waren. Mede op initiatief van deze commissie werden door het Nederlands ziekenhuis Instituut, in samenwerking met de Landelijke Specialisten Vereniging, taakanalyses van meerdere klinische specialisaties gemaakt. Voor de huisartsentaak bleek eveneens behoefte aan een dergelijk type onderzoek, zonder dat overigens duidelijk was binnen welke kaders een dergelijke studie zou moeten plaatsvinden. 
Naast deze behoefte aan cijfermatige beschrijving van het takenpakket van huisartsen was een tweede impuls voor het onderhavige onderzoek gelegen in de sfeer van de reeds eerder genoemde beleidslntentle, gericht op versterking van het eerste echelon. Wanneer immers deze versterking beleidsmatig moest worden ondernomen of ondersteund, dan was het een eerste verelste om te weten welke matregelen getroffen moesten worden om de gewenste effecten tot gevolg te hebben.

Gedacht werd aan:

- praktijkverkleining, noodzakelijk on huisartsen in de gelegenheld te stellen meer aandacht aan patiënten te besteden;

- hierdoor wordt (mogelijk) het verwijscijfer verlaagd en kunnen per saldo dezelfde gezondheldszorgtaken goedkoper worden vervuld, zonder verlies van kwaliteit, (Rutten, Van der Gaag en Van Praag, 1975; Van der Wal1, 1980);

- verschuivingen in het takenpakket van de huisarts naar meer preventief gerichte activitelten, bewerkstelligd door enerzijds praktijkverkleining, anderzijds door het aanbieden van therapeutisch-diagnostische faciliteiten an huisartsen in de vorm van ziekenhuislaboratoria, diagnostische centra, e.d. (Puylaert, De Melker, 1980);

- samenwerking met andere disciplines die het werk van de hulisartsen verlichten, waardoor taken als begeleiding van bejaarden en chronische zleken meer aandacht kunnen krijgen, (De Melker, 1973; Ten Cate e.a., 1977; Dokter, Van der Grinten en De Jong, 1974).

Een bloemlezing uit artikelen in tijdschriften als "Huisarts en Wetenschap", "Medisch Contact", "De Eerste Lijn", kan deze enkele voorbeelden van geuite veronderstellingen met vele ultbreiden. Telkens is er sprake van gewenste en vermoede veranderingen in het functioneren van huisartsen, als gevolg van veranderingen in de organisatorische werksfeer.

Een belangrijke veronderstelling achter deze vermoedens is gelegen in opvattingen omtrent vraag en aanbod in de gezond- 
heidszorg. De literatuur over dit onderwerp is grofweg als volgt samen te vatten, (Van Praag e.a., 1973; Huysmans e.a., 1973; Posthuma en Van der Zee, 1978; Harris, 1975). De vraag naar diensten in de gezondheidszorg is nagenoeg oneindig elastisch. Een nieuw aanbod creëert een nieuwe vraag: uitbreiding van gezondheidszorgvoorzieningen leidt tot een toenemende vraag naar deze voorzieningen. Het economisch mechanisme van de vrije-markt-economie, waarin een autonome vraag en aanbod-situatie tot een evenwichtsverhouding komt bij een bepaalde prijs, geldt zeker niet in de gezondheidszorg. Velen hebben inmiddels gewezen op de noodzakelijke nuanceringen die aangebracht moeten worden in een dergelijke vraagen aanbod-beschouwing, (Fuchs, 1980; Osterson e.a., 1981). Natuurlijk zijn extreme situaties te bedenken waarbij ook in de gezondheldszorg sprake is van een autonome vraag, of een aanbod waardoor geen of nawwelijks een vraag wordt geInduceerd. In de huidige Nederlandse gezondheidszorg echter, worden veelvuldig ulteenlopende vormen van medische hulpverlening bestempeld als een zeer sterk door de aanbodzijde geinduceerde zorg.

Naast de economische beschouwing omtrent vraag- en aanbodverhoudingen in de gezondheidszorg, moet ook een meer sociologische benadering worden vermeld. Indien men de vele studies omtrent het artsenberoep als professie beziet, valt naast een groot aantal veschillen op, dat unaniem als professiekenmerk de autonomie van beroepsmatig handelen wordt genoemd, (KIinkert, 1980; Lulofs, 1981). In de professietheorieën van Johnson (1972) en van het echtpaar Parry (1976), die dicht tegen de economische beschouwingen aanleunen, worden professies beschouwd als beroepsgroepen die bij machte zijn om zelf hun markt van diensten te reguleren op grond van meer of minder legitiem verworven rechten en posities. Het exclusief geclaimde kennisgebled makt het de professie mogelijk om te bepalen wat wel en niet noodzakelijk geacht moet worden voor de consument/patiënt. Op het individuele niveau van de arts-patiënt-relatie kan dit tot uiting komen in min of meer autonoom medisch bepaald aanbod van noodzakelijk geachte hulpverlening. Op collectief niveau vindt de op gezondheid gerichte voorlichting plaats op een dusdanige wijze, dat steeds meer voor algemene vragen en problemen een medisch-technische oplossing aanwezig lijkt te zijn (medicalisering). 


\subsection{SAMENVATTING}

De situatie $\mathbb{A n}$ de Nederlandse gezondheldszorg in het midden van de zeventiger jaren werd gekenmerkt door een zeer sterke aandacht voor de rol en functie van de huisarts. Ondanks vele discussies, rapporten en beleidsvoornemens bleef de kwantitatieve informatie ontrent het door huisartsen verrichte werk gering. De behoefte aan cijfermatige onderbouwing groelde, naarmate meer, vaak tegengestelde, veronderstellingen ontrent taakultoefening, praktijkomvang en gewenst functioneren geuit werden.

Het onderhavige onderzoek is gericht op het empirisch beschrijven van de huisartsentaken naar hun omvang en inhoud. Bovendien wordt gezocht naar verklaringen van eventuele verschillen In taakuitoefening, die gelegen kunnen zijn in organisatorische omstandigheden van praktijken en uiteenlopende taakopvattingen van huisartsen. Op grond van de veronderstelde vraag-aanbod-verhouding wordt de feitelijk gepresenteerde vraag naar hulsartsenzorg in alle onderzochte gevallen gelijk gesteld. 
HOOFDSTUK 2

PROBLEEMSTELLING EN LITERATUUR

\subsection{PROBLEEMSTELLING}

Vanuit de hiervoor beschreven omstandigheden is de volgende probleemstelling ontstaan:

a) welke functies vervult de huisarts in de Nederlandse gezondheidszorg;

b) zijn verschillen in functie-uitoefening te verklaren vanuit: taakopvatting van de huisarts, persoonskennerken en de gezondheldszorgstructuur?

Om het totale pakket van activiteiten, dat hulsartsen gedurende hun dagelijkse praktijkuitoefening verrichten, te rubriceren, moet allereerst een kader geformuleerd worden waarbinnen een samenhangend overzichtelijk geheel kan worden beschreven. De hoofdlijnen voor dat kader worden aangeduld met functies welke zijn afgeleid van de plats die de huisarts in de structuur van de Nederlandse gezondheldszorg bezet.Ten behoeve van de meting worden deze functies gespecificeerd in activiteiten, die worden geoperationaliseerd in observatiecategorieën.

Naast deze voor de analyse gebruikte omschrijvingen van functies en activiteiten, zal als taak van de hulsarts worden beschouwd: het geheel van normatlef gestelde werkzaamheden dat volgens de huisarts zelf of volgens anderen - zoals bijwoorbeeld de L.H.V.- verricht moet worden.

De registratie van door huisartsen verrlchte activiteiten gedurende de onderzoekperiode, zal naar verwachting een per huisarts verschillend patroon van functievervulling opleveren. Verondersteld wordt dat deze verschillen voor een gedeelte terug te voeren $z i j n$ op de persoonlijke taakopvatting die de huisarts heeft en zijn ervaring als huisarts. Boven- 
dien kunnen verschillen ontstaan door de onderscheiden praktijkkenmerken waarbinnen de huisarts werkzaam is. Tenslotte kunnen ook de regionale omstandigheden - en met name de voorzleningen op het terreln van gezondheids- en welzijnszorg - nog van invloed zijn op het uiteindelijke patroon van functievervuliting door de huisarts.

In hoeverre verschillen in de feitelijke vraag naar huisartsenhulp - "het klachtenpatroon" - van betekenis zijn voor de gemeten takenpakketten wordt in dit onderzoek niet nader onderzocht. We gaan er vanult dat een deel van de geboden gezondheldszorg wordt bepaald door factoren uit de aanbodzijde, ongeacht de hulpvraag. Het zijn ook juist deze factoren, die door het beleid in meer of mindere mate direct te beinvloeden zijn. De demografische kenmerken van de bevolking in de gemeenten waar de huisarts praktiseert, zullen als controlevariabelen worden beschouwd.

Figuur 1: Probleemstelling in schema

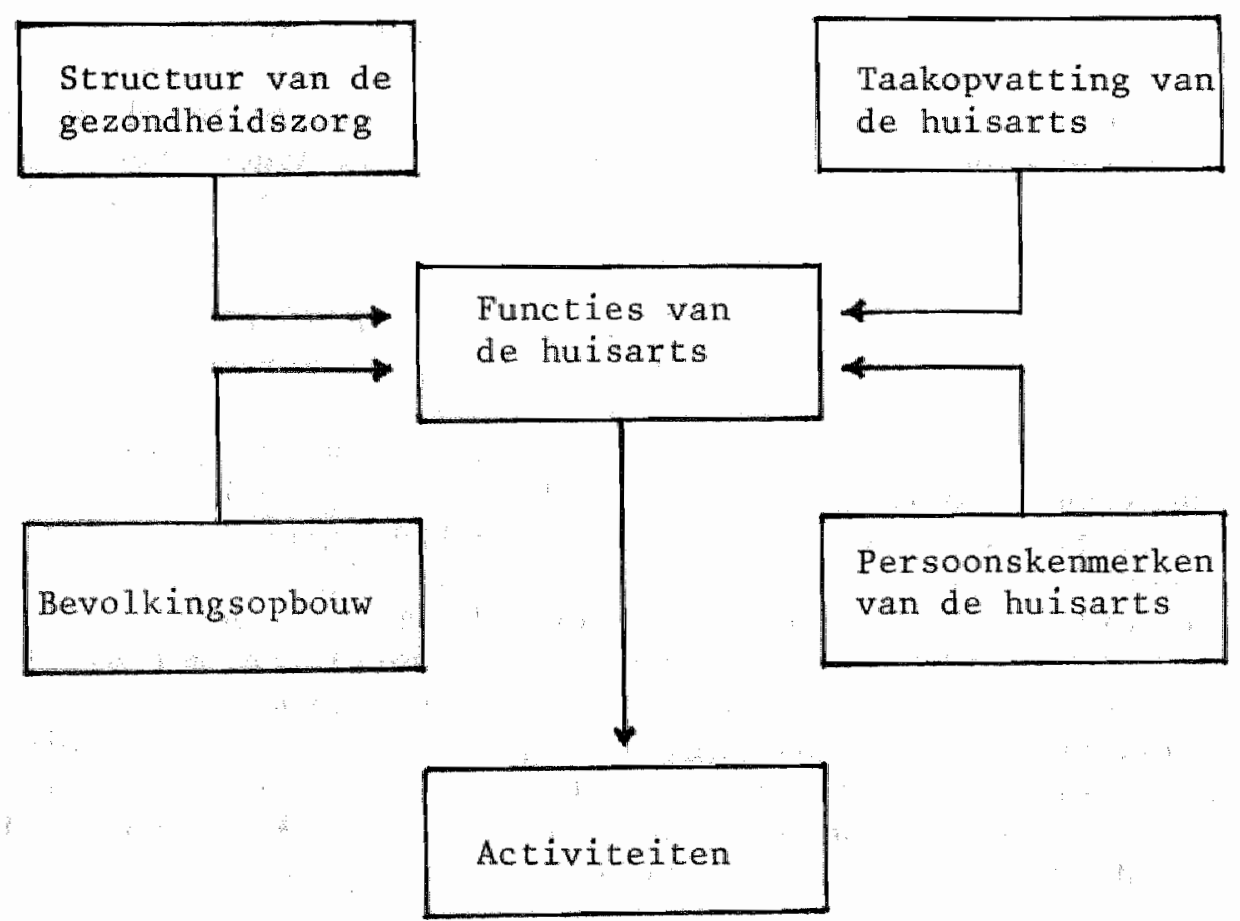




\subsection{PROBLEEMSTELLING EN LITERATUUR BIJ FUNCTIEBESCHRIJVING}

De omvangrijke hoeveelheid literatuur die bij het eerste deel van de probleemstelling kan worden genoemd, bevat weliswaar geen vergelijkbaar empirisch onderzoek, maar biedt wel aanknopingspunten waarvan bij de uitvoering van de probleemstelling gebruik kan worden gemaakt.

Grofweg kan deze literatuur worden ingedeeld in 4 categorieën, die successievelijk besproken zullen worden in de volgende paragrafen.

a) Omschrijving van taken van huisartsen door en vanuit de beroepsgroep zelf: par. 2.2.1.

b) Omschrijving van de ontwikkeling van het huisartsenberoep, veelal vanuit professie-studies: par. 2.2 .2 .

c) Onderzoek gericht op taakvervulling door (huis-)artsen in relatie tot mogelijke substitutie; vaak vanuit een beleidsmatig manpower-planning-perspectief: par. 2.2.3.

d) Onderzoek gericht op de beschrijving van het inhoudelijk hulpverlenersgedrag, al dan niet in directe relatie tot praktijk- en/of persoonskenmerken: par. 2.2 .4 .

\subsubsection{HUISARTSEN OVER HUN BEROEP}

De grote lijn in dit type literatuur kan als volgt worden getrokken. Als uitgangspunt kan het bekende "Woudschoten rapport" dienen, genoemd naar een N.H.G.-conferentie te Woudschoten op 23 en 24 januari 1959. Reeds vele malen is de daar voor het eerst geformuleerde taakomschrijuing bediscussieerd, bekritiseerd, aangevuld en verworpen. Het ideaalbeeld wordt door het N.H.G. als volgt gesteld: "Het Nederlands Huisartsen Genootschap ziet de functie van de huisarts als het aanvaarden van de verantwoordelijkheid voor een continue, integrale en persoonlijke zorg voor de gezondheid van de zich aan hun toevertrouwde individuele mensen en gezinnen. Het ziet deze zorg als het opheffen, in hun uitwerking beperken en waar mogelijk voorkòmen van stoornissen in de individuele of gezinsgezondheid (curatief, revaliderend, preventief)", (N.H.G., 1959, pag. 4). 
Op deze zelfde conferentie wordt door de comissie wetenschappelijk onderzoek op grond van onderzoek door J. Buma, een aantal deel taken geformuleerd:

1. eerste hulp, ook voor psychlsche traumata;

2. somatisch onderzoek;

3. psychisch en soclaal onderzoek, waarbij de beheersing van een goede gespreks- en anamnese-techniek essentieel 1s;

4. registratie en beheer van alle medische gegevens;

5. differentiatie van de patiënten in twee groepen: namelijk in een groep waarvan de behandeling binnen de dagelijkse routine valt en een groep die afzonderlijke behandeling vraagt door het gecompliceerde van haar bijzondere problematiek;

6. behandelen, wat door hem behandelbaar is;

7. ad hoc en tijdelijk delegeren naar medische en andere deskundigen, warbij zijn medeverantwoordelijkheid blijft bestaan;

8. In overleg met behandelende en adviserende medisch-speclalisten en andere deskundigen opstellen van een nazorgplan en zorg voor de uitvoering daarvan;

9. integratie en coördinatie van de zorg voor de zieke, invalide en onaangepaste mensen door een goede samenwerking met andere deskundigen, waar nodig in teamverband;

10. bijdragen tot preventie;

11. bijdragen tot gezondheidsvoorlichting en -opvoeding;

12. blijven werken aan eigen deskundigheid en vorming met een open oog woor eigen mogelijkheden en grenzen, (N.H.G., 1959, pag. 1 en 2).

De betekenis van deze omschrifving 1 igt vooral in de normatieve sfeer: in de daarna komende 20 jaar zal de alomvattende "continue, integtale en persoonlijke" zorg als een loodzware last op de hulsarts drukken of hem steunen in het uitbrelden van zijn werkgebled, al naar gelang de omstandigheden vereisen. Nog in 1979 zucht Tielens, voormalig voorzitter van het N.H.G., dat de huisarts nog steeds met een "Woudschoten-kater" zit opgescheept, (Tielens, 1979). Als heilzaam middel tegen de kater beschouwt hij de eerste aanzetten tot een theoretische fundering onder de taakstelling voor huisartsen, gegeven door Van Aalderen (1974), uitgewerkt in het N.H.G.-rapport "Methodisch werken", (N.H.G., 
1978). Als vervolg op het interim-rapport "Hoe helpt de dokter", (N.H.G., 1975), wordt geprobeerd de ideaal-stelling van Woudschoten meer realistisch te maken. De zeer breed gedefinieerde taakstelling voor huisartsgeneeskunde ut het Woudschotenrapport wordt niet ingeperkt, maar de huisarts krijgt hulptroepen.

"Op grond van onze overwegingen betreffende de behoefte aan hulp, de mogelijkheden van de huisarts en de verantwoordelijkheid voor de hulpverlening pleiten wij voor de volgende doelstelling:

- openstaan voor alle vragen om hulp. De vragen worden samen met de patiënt verhelderd om te beoordelen welke deskundigheid voor de hulpverlening geboden is;

- samen met de patiënt een keuze maken uit de mogelijkheden voor hulp en dienovereenkomstig handelen, hetzij zelfstandig dan wel in samenwerking met anderen'", (N.H.G., 1978, pag. 323).

De onbeperkte invoer in het gezondheidszorgsysteem wordt niet alleen geaccepteerd, maar bovendien verheven tot basis voor legitimering van het systematisch methodisch werken van de huisarts. Hij moet immers in staat gesteld worden om uit de amorfe hulpvraag van de patiënt te destilleren welke hulpverlener het meest adequat kan worden ingeschakeld. Een dergelijke ongedefinieerde invoer is niet zonder meer vanzelfsprekend en kan zelfs tot éen van de hoofdredenen worden bestempeld voor het onbestuurbaar zijn van de gezondheldszorg, zoals reeds eerder door Philipsen is betoogd. "De gezondheldszorg is namelijk een systeem met een ongedefinieerde invoer geworden. Iedereen kan met elk probleem dat hij definieert in termen van gezondheld, geluk of welzijn in de gezondheidszorg terecht en wordt behoudens bezwaren van infrastructurele aard dezelfde dag geholpen. De gezondheidszorg is één van de weinige matschappelijke instanties die geen zeggenschap meer hebben over de invoer van de te behandelen problemen," (Philipsen, 1976, pag. 54).

Wordt naast het loket met ongedefinieerde begrenzing nog gelet op de toegenomen belangstelling voor niet alleen curatief, maar toch vooral ook preventief, anticiperend werken, dan is daarmee de oude Woutschoten-traditie nog in alle dui- 
delijkheid aanwezig, zelfs nog uitgebreid, (Huygen, 1978). Alleen $1 \mathrm{~s}$ nu de hulsarts de spil in een team van eerstelijnswerkers, waarmee nog niets concreets gezegd is over welke zijn spectfleke taken in deze omstandigheden zouden moeten zijn. De huisarts blijft zoeken naar zijn identiteit, de wetenschappelijke fundamenten van zijn vakgebied, (Van Es, 1978; De Geus, 1978).

Aan opsomming van een $11 j \mathrm{st}$ concrete activiteiten heeft het N.H.G. zich niet gewaagd. Niet vreemd, als men het Genootschap toch meer ziet als studerend, wetenschappelijk bezig zijn met het huisartsenberoep, terwijl de feitelijke belangen behartigd worden door de L.H.V. In deze sfeer van zake1 ijke belangenbehartiging moeten ook meer concrete punten op tafel komen bij onderhandelingen met verzekeraars en overheid ontrent honorering, praktijkonvang, inschaling en vestigingsbeleid.

Een eerste uitspraak omtrent het takenpakket wan de hulsarts deed het L.H.V.-bestuur in de "Blauwdruk" in 1975, (L.H.V., 1975). De hierin centraal gestelde beleidsvoornemens, te weten: limitering van de praktijkgrootte, vestigingsbeleid en intercollegiale toetsing, hebben directe relaties met de veronderstelde veranderingen, met name verzwaring in de taakuitoefening van de huisarts. Aangekondigd wordt dat een duidelijke omschrijving van het takenpakket op korte termijn is te verwachten. De hiertoe ingestelde "Commissie Takenpakket" kont in 1976 met een interimrapport, (L.H.V., 1976).

De comissie heeft als taakopdracht:

1. op korte termijn inventariseren hetgeen reeds gepubliceerd is op het gebied van het takenpakket van de huisarts;

2. opstellen, rubriceren van de taken van de huisarts;

3. t1jdsbeslag van deze taken berekenen voor de gemiddelde dagtaak op jaarbasis, (L.H.V., 1976, pag. 1).

De inmiddels concreet geworden voornemens voor ons onderzoek bleken overeenkomsten en aansluitpunten te hebben met het gestelde 1 punt 3 in de takstelling van de commissie. Het in december 1976 gevoerde overleg met de genoemde commissie leldde echter niet tot een concrete vorm van samenwerking. 
De inhoud van het interimrapport, in 1977 in definitieve vorm gepubliceerd, (L.H.V., 1977), vormt wel een referentiepunt bij de nog volgende operationalisering van de "functies van de huisarts" ten behoeve van de observaties. (Hoofdstuk 3) Als uitgangspunt kiest de comissie een indeling in "Hoofdtaken en facultatieve taken", dit in tegenstelling tot de indeling in "Hoofdtaken, facultatieve en oneigenlijke taken", die door de "K.N.M.G.-Commissie Eerste Echelon" wordt gehanteerd.

Deze commissie kwam in januari 1976 met haar rapport, opgesteld op grond van een opdracht, die verstrekt werd door het hoofdbestuur van de K.N.M.G. in 1973, (K.N.M.G., 1976). Omdat beide rapporten, van de K.N.M.G.- en de L.H.V.-werkgroep, bij de operationalisering in ons onderzoek een centrale rol spelen, wordt bij hun afzonderlijke inhoud en onderlinge vergelijking langer stilgestaan.

Als belangrijkste verschil tussen de twee rapporten kan worden vastgesteld dat de L.H.V. -werkgroep een uiterst gedetailleerde opsomming geeft van al dan niet facultatief door de huisarts te verrichten handelingen, behorende bij de gestelde hoofdtaken. Met deze handelwijze wordt aangesloten bij het rapport "Kenmerken van de huisarts", (U.H.I., 1975), dat in sommige huisartsopleidingen wordt gebruikt.

Daarentegen specificeert de K.N.M.G.-groep een aantal algemene doelstellingen voor de huisartsentaak, waaruit vervolgens de afzonderlijke hoofdtaken, facultatieve en oneigenlijke taken worden afgeleid. Deze werkgroep kont zo tot de volgende hoofdtaken: (K.N.M.G., 1976, pag. 145, 146):
a) diagnostiek
b) therapie
c) individuele preventie
d) samenwerken met andere disciplines
e) medische coördinatie
f) advisering bij werkhervatting
g) selectie en verwijzing
h) signalering
i) medisch-sociaal functioneren
j) praktijkorganisatie en registratie
k) nascholing
i) intercollegiale toetsing. 
Als facultatieve taken worden genoend, (K.N.M.G., 1976 pag. 49):

a) behandelingen en begeleiding van chronisch psychiatrische patiënten

b) groepspreventie

c) opleiding en begeleiding van aankomende huisartsen

d) onderwijs

e) diagnostlek.

In de toellchting wordt duidelijk dat voor diagnostiek hier gelezen moet worden: uitgebreide diagnostiek met behulp van instrumentaria, zoals voor het maken van ECG's en audiogrammen.

Bij groepspreventie wordt gedacht aan de medewerking aan het consultatlebureau voor zufgelingen en kleuters en de supervisie bij gericht screeningsonderzoek, bijvoorbeeld portioscreening.

Onelgenlijke taken voor de huilsarts zijn: (K.N.M.G., 1976, pag. 149):

a) behandeling van bepaalde ernstige vormen van psychosociale problematiek

b) het zoeken van oplossingen voor strikt sociale problemen

c) het doen van partussen in een te gering aantal

d) het verlenen van hulp bij straatongevallen

e) groepspreventie

f) het verrichten van keuringen.

Wanneer de hulsarts op deze wijze zijn takenpakket opvat hoopt de werkgroep dat het mogeljk wordt als centrale doelstellingen te bereiken: (K.N.M.G., 1976, pag. 115)

- een beperking van zijn werk en

- een verkleining van zijn praktijk.

Ondat dergelijke doelstellingen alleen bereikt kunnen worden wanneer ook veranderingen in de totale werksituatie van de huisarts doorgevoerd worden, formuleert de werkgroep ook de noodzakelijk geachte structuur van het eerste echelon en verbindingen met het tweede en derde echelon.

Hiermee presenteert de K.N.M.G-commissie een totaalbeeld dat als beleidsplan zou kunnen dienen, zowel voor de huisartsenorganisaties als voor de overheid, bij een beleid dat ge- 
richt is op versterking van het eerste echelon, integratie en systematisering van de verschillende onderdelen van de gezondheidszorg.

De L.H.V.-groep, gebelgd door het betitelen van door huisartsen verrichte activiteiten als "oneigenlijke taken", gaat zeer nauwkeurig aangeven wat de huisarts in ieder geval moet doen (hoofdtaken) en wat hij nog wel kan doen, maar alleen als de mogelijkheden hem daartoe in staat stellen (facultatieve taken).

Hoofdtaken zijn:

a) diagnostiek

b) therapie

c) kwaliteitsbewaking

d) individuele preventie en anticiperende geneeskunde

e) samenwerkend functioneren

f) verwijzing, coördinatie en werkadviezen

g) organisatie, registratie, signalering

Facultatieve taken zijn:

a) verloskunde

b) opleiding

Bovendien zijn een aantal, per hoofdtaken gespecificeerde, activiteiten als facultatief te beschouwen. Bijvoorbeeld: bij het diagnostisch proces: het hanteren van specifieke gesprekstechnieken, of bij het algemeen lichamelijk onderzoek: het gebruiken van de peak-flowmeter, proktoskopie, e.d. Deze splitsing naar facultatieve onderdelen per hoofdtaak wordt volgehouden in de gehele uitvoering en gedetailleerde uitwerking. Hieruit resulteert bijvoorbeeld een onderscheid als: hoofdtaak bij "oogheelkunde": het bepalen van de visus bij kinderen en volwassenen; facultatlef : het kwantitatief bepalen van visusafwijkingen door middel van sfem rische en cylindrische correctie. Of, bij "gynaecologie/verloskunde" als hoofdtaak: de vroegdlagnostiek van zwangerschap door middel van gynaecologisch en laboratoriumonderzoek; als facultatief: het prenataal onderzoek.

Belangrijk in het kader van ons onderzoek is de discussie omtrent de afbakening van het werkterrein van huisartsen ten opzichte van andere medische en niet-medische beroepsgroepen. Of deze dicussie nu in termen van algemene doelsteli in- 
gen wordt gevoerd, of nauwkeurig per handeling wordt gespeciflceerd, de vrijwel allesomvattende taakstelling van het "Woudschoten rapport" blijft gehandhaafd.

Alle geformuleerde takenpakketten blijven op het niveau van meningen en voornemens; aan een empirische onderbouwing gericht op aspecten als omvang, onderlinge verhouding en afstemming van taakdelen wordt geen aandacht besteed. Toch beschouwt de "Nieuwe Blauwdruk" het takenpakket als ingevuld In vergelijking met de oude Blauwdruk van 1975. De hierop gebaseerde beleidspunten: "daling rekennormpraktijk, maximering van praktijkgrootte", verwijzen expliclet naar het pakket taken dat de L.H.V.-werkgroep heeft geformuleerd. Met verwijzing naar het rapport "De taken van de huisarts" is duidelijk dat - wil de huisarts adequat functioneren en maatschappelijk gezien niet continu overbelast zijn - de huisartsenpraktijk verkleind moet worden.

De meest recente fase in het beleid van de L.H.V. laat een ontwikkeling zien die aansluit bij eerder door het N.H.G. over de werkwijze van huisartsen geformuleerde normen. Naast het samenwerken met andere disciplines, moet de huisarts ook rekening gaan houden met de mondige patiënt. Deze kiest zelf de voor zijn gezondheid belangrijke zaken.

"De functie van de huisarts is gericht op het helpen van mensen bij het maken van keuzen - en bij de realisering daarvan - ter bevordering of instandhouding van hun welbevinden en optimaal functioneren, lichamelijk, geestelijk en soclaal. Als zodanig draagt de functie bij aan de doelstelling van de gezondheldszorg als geheel," (L.H.V., 1981, pag. 1474). Een concreet gesteld pakket van actiepunten ten behoeve van het onderhandelingsbeleid met overheld en zlekenfondsen ontbreekt in deze functieomschrijving, dit in tegenstelling tot de visies in belde Blauwdrukken.

Een jaar later wordt de functieomschrijving van de huisarts door de L.H.V. geconcretiseerd in een nieuw takenpakket, (L.H.V. 1982). In dit takenpakket is de meest recente visie op de functie van de huisarts verwerkt. In niet minder dan 115 taken wordt gesteld wat de huisarts behoort te doen; niet alleen op de zulver medisch-technische terreinen zoals dat in het takenpakket van 1976 gebeurde. Ook de samenwerking met andere hulpverleners, het methodisch werken en de 
mondige patiënt zijn in het nieuwe pakket opgenomen. Van dit nieuwe en omvangrijke pakket verklaart het Centraal Bureau van de L.H.V.:"..... dat het een rol kan spelen bij de honorering. In het modelcontract tussen huisarts en ziekenfonds zou het kunnen worden opgenomen, met dien verstande dat het basistakenpakket tenminste de aard en omvang van de huisartsenhulp aangeeft," (L.H.V., 1982, pag. 5).

\section{Samenvattend:}

De huisartsen hebben zich bij monde van hun beroepsgroep voortdurend beziggehouden met bezinning op een (her)formulering van hun taken. De in 1959 geformuleerde "breed-spectrum"-visie werd in de zeventiger jaren verder uitgewerkt onder invloed van structureringsvoornemens van de overheid en de hiermee samenhangende herformulering van de plaats van de huisarts in de gezondheidszorg. De meer of minder gepreciseerde inhoudelijke taken, die daaruit volgden, resulteerden in eisen tot verlaging van de rekennorm en maximering van praktijkgrootte; een empirische beschrijuing werd niet ondernomen.

In het meest recent verschenen takenpakket worden ook nadere denkbeelden over werkwijze en werkhouding van de huisarts opgenomen; dit geheel vormt de inzet van de onderhandelingen over de honorering.

\subsubsection{HET HUISARTSENBEROEP ALS PROFESSIE}

De hilerboven geschetste inspanningen door de beroepsgroep van huisartsen kunnen worden gezien in het licht van de voortgaande professionalisering. De literatuur die het professionaliseringsproces van artsen beschrijft is omvangrijk. ook neemt de aandacht die hierbij geschonken wordt aan $\mathrm{Ne}^{-}$ derlandse huisartsen de laatste jaren snel toe, (Van HoveBaeck, 1978; Van der Krogt, 1981).

Gelijktijdig hiermee wordt ook de soclologische theorievorming omtrent het professie-begrip verder uitgewerkt, (Klinkert, 1980).

De door Van Hoof (1969) gemaakte twee-deling in beroepenstudies volgend, kunnen deze studies beschouwd worden als zich bewegend op het hoogste abstractieniveau: "het doel is 
een beschrijving van het beroep als zodanig, van processen, instituties, warden en normen, los van de individuele beroepsbeoefenaars.

.... Het resultat is een verwarlozing van de individuele variatie binnen het beroep, zodat het doorgaans onmogelijk is de jufstheid en volledigheid van het eindbeeld te controleren, en een latent aanwezige tendens tot reificatie", (Van Hoof, pag. 53).

Wanneer we in deze studie de taken willen beschrijven zoals die door de verschillende Nederlandse huisartsen worden ultgeoefend, drelgen we te vervallen tot het laagste abstractieniveau van de genoende twee-deling. ".......doel is de verklaring van de individuele verschillen in gedragingen, opinies en houdingen...... Het resultaat is hier de verwaarlozing van de betekenis van het beroep als referentiekader voor de individuele beroepsbeoefenar en een eindbeeld waarin de verscheidenheid domineert, doch men over de eenheid in het onzekere blijft," (Van Hoof, 1969, pag. 53). On aan de tekortkomingen van beide vormen van beroepenstudies te ontkomen, suggereert Van Hoof als uitgangspunt het beroep te beschouwen als institutie. "Door uit te gaan van een interpretatie van het beroep als een in meer of mindere mate geinstitutionaliseerd sociaal kader, wordt de aandacht evenwel automatisch gevestigd op de gedragsbepalende invloed die van het beroep zelf uitgaat," (Van Hoof, 1969, pag. 60).

Deze raadgeving heeft voor de ultwerking van onze probleemstelling consequenties. Zonder een alomvattende indicering van het institutionaliseringsproces bij Nederlandse huisartsen na te streven, willen we de hierboven beschreven ontwikkelingen in het denken over taakinhoud en-afbakening gebruiken als centraal element van institutievorming. De gedachtenvorming rondom de inhoud en afgrenzing van het werkgebied van de beroepsgroep kan beschouwd worden als een kristallisatlepunt voor het sociaal en cultureel kader waarin de beroepsbeoefenaren werken. De centrale beroepsorganen - L.H.V. en N.H.G. - kanaliseren en stimuleren deze gedachtengang en treden tevens op als representant ten opzichte van andere beroepsgroepen en de overheid. De aldus gevoerde discussie leidt tot een geconstrueerde realiteit die institutionaliseringselementen verkrijgt, (Berger en Luchman, 1966). Bij de meting van de takopvatting zal het takenpakket dat door 
de beroepsorganen van de huisartsen is geformuleerd, tot uitgangspunt dienen voor de op te stellen vragenlijst. De mate van overeensteming onder individuele beroepsbeoefenaren kan vervolgens als een indicator worden beschouwd voor het welslagen van deze institutionalisering.

Samenvattend:

De beroepenstudies met betrekking tot artsen en huisartsen zijn vrijwel uitsluitend gericht op beschrijving van een professionaliseringsproces. Het hieraan klevende bezwaar: boven-individuele groepsbeschouwing met gevaar voor reificatie, wordt onvoldoende ondervangen door taakdescriptie van individuele beroepsbeoefenaren met nadruk op geconstateerde verschillen. Een tussenoplossing wordt mogelijk gevonden in het invoeren van een institutionaliseringsproces, dat ener$z i j d s$ tot stand komt op basis van taakdiscussies en anderzijds zijn invloed heeft op de feitelijke functie-uitoefeming. Een analyse van de taakpercepties op het punt van individuele verschillen en overeenkomsten biedt aanknopingspunten voor een inzicht in het institutionaliseringsproces.

\section{2 .3 . OUTPUTMETING}

Een afzonderlijk literatuurgebied betreft de vrijwel uitsluitend buitenlandse beschrijvingen van outputmeting, veelal in relatie tot manpower-planning. Indien een planning van het aantal benodigde artsen wordt ondernomen is het noodzakelijk om, naast kwantificering van instroom, uitstroom, vervanging en aanbod, inzlcht te hebben in de mate warin de geproduceerde diensten beantwoorden aan de bestaande en te verwachten vraag, (Ahamad and Blaug, 1973).

De relatie vraag - aanbod speelt in de gezondheidszorg een uitzonderlijke rol. De mate warin het aanbod van hulpverlening door de gezondheidszorg beantwoordt aan de vraag hiernaar, is moellijk vast te tellen. Bovendien is het van belang te weten in hoeverre de bestaande beroepen als onderling substituerend kunnen worden beschouwd wat betreft hun dienstverlening.

In Nederland zijn beschouwingen omtrent behoefte aan artsen niet verder gekomen dan kwantificering van de bestaande arts/populatie-ratio, waarna geconstateerd werd dat bij deze 
ratio toch een "voldoende kwalltatief niveau van zorgverlening" werd gewaarborgd. Hierult worden voorspellende berekeningen gemaakt om deze ratio minstens te handhaven op basis van te verwachten ontwlkkelingen in studentenaantalien, bevolkingsgroei, e.d. (Poorter, 1977).

Voor ons onderzoek zijn de outputmetingen die in meer of mindere mate in relatie met manpower-planning of substitutie ondernomen zijn, van belang, omdat de hierbif gehanteerde produktiefuncties meestal taken in de vorm van gekwantificeerde verrichtingen bevatten, (Reinhardt, 1972, 1973; Butter, 1972; Donaldson, 1971; Kimbe11, 1977). Daar het veela1 Amerikaans onderzoek betreft, zijn de resultaten niet verge11jkbaar, in sommige opzichten wel de meetmethoden. onderzoek gerlcht op outputmeting ten behoeve van het opstellen van kwaliteitscriteria, bevindt zich nog slechts in een zeer pril stadium van ontwikkeling, (Riedel and Riedel, 1979). Bovendien begeeft dit onderzoek zich in een meer medisch-technische richting door bijvoorbeeld het zoeken naar protocollen of standaarden voor behandeling, hetgeen voor ons niet relevant is.

\section{Samenvat tend:}

Het onderzoek gericht op taakkwantificering van (huis)artsen betreft vrijwel uftsluitend buitenlandse studles, gebaseerd op het toepassen van produktiefuncties, waarvan de betekenis voornamelijk is gelegen op het vlak van kostenbeheersing en besturing door managers en politici. De relevantie voor ons onderzoek is gelegen in de gehanteerde meettechnieken van takkonderdelen en kwantificering van verrichtingen.

\subsubsection{EMPIRISCH ONDERZOEK NAAR PRAKTIJKUITOEFENING}

Tenslotte moet bij het eerste deel van de probleenstelling nog vermeld worden de literatuur die gebaseerd is op onderzoek betreffende (deel)activiteiten van en onderdelen uit het werk dat Nederlandse huisartsen doen. De zeer uiteenlopende probleemstellingen, methodische opzet en vormen van gegevensverzameling die de onderzoekers hierbij hebben gehanteerd maakt onderlinge vergelijking van de resultaten weinig zinvol. 
De plaats die ons onderzoek in dit geheel inneemt, blijkt uit een beschrijving van het reeds onderzochte terrein. Een overzicht van dit gebied wordt gegeven aan de hand van de volgende indeling:

1) inventariserende beschrijuingen van alle werkzaanheden van huisartsen, in één of meerdere praktijken geregistreerd, in relatie tot morbiditeitsgegevens, persoonsen praktijkkenmerken: par. 2.2.4.1;

2 ) onderzoek toegespitst op inhoudelijke deelactiviteiten zoals verwijzen naar en andere relaties met hogere echelons, beschrijving van klachten - en probleemaanbod in relatie tot diagnose-categorieën alsmede beslissingsprocessen en kwaliteit van zorg, par. 2.2.4.2.;

3) onderzoek naar de organisatorische vorm van de huisartsenpraktijk, zoals samenwerkingsverbanden van huisartsen onderling en van huisartsen met andere eerste echelonwerkers, alsmede werkrelaties en structuurvormen van huisartsen met hulpverleners uit andere dan het eerste echelon: par. 2.2.4.3.

\subsubsection{HET WERK VAN DE HUISARTS}

Naast een aantal in één praktijk uitgevoerde beschrijuingen (o.a. Van Deen, 1952; Buma, 1952; Bremer en Van Westrenen, 1964; Ruhe, 1957; Hogerzei1, 1957), zijn in Nederland bijna als meest belangrijke informatiebronnen op dit terrein te beschouwen de onderzoeken van Oltemans (1969), Van der Wielen (1960), Jansen-Emmer (1958), en Raupp (1972). Ieder is op een eigen terrein in meer of mindere mate baanbrekend.

Oliemans geeft een indeling van morbiditeitsgegevens uit de huisartsenpraktijk, die te zien valt als aanzet van en ultgangspunt voor de opzet van peilstations en het intermitterend morbiditeitsonderzoek. Gegeven de probleemstelling van ons onderzoek, waarin de registratie van de morbiditeitspatronen niet is opgenomen, $z i j n$ de uitkomsten van onderzoek gedaan door oliemans, en anderen in navolging hiervan, voor ons onderzoek weinig relevant. 
Het werk van Van der Wielen is uitzonderlijk in zijn poging om de kwalitatieve betekenis van het huisartsenaandeel in de gezondheldszorg in kaart te brengen. Zonder hier verder in te gaan op de methode van gegevensverzameling en de operatonalisering van de gebruikte begrippen, moet toch zijn opmerkelijke eindconclusie worden weergegeven:

"....de doeltreffendheid van de door huisartsen gegeven gezondheidszorg is groter:

a) wanneer meer tijd per contact huisarts-patiënt beschikbaar is;

b) bif die artsen die een positieve instelling hebben tegenover het huisarts-zijn en tegenover hun huidige werkkring en die daarnaast door hun levenshouding bijdragen tot het aanzien der geneeskunde en de stand der geneeskundigen;

c) onder omstandigheden van geven en ontvangen van gezondheidszorg zoals deze voorkomen in praktijken, die zijn gevestigd in een gebied, dat overwegend valt te typeren als agrarisch platteland. Hierbij bestaat geen zekerheld, dat dit laatste het beslissende kenmerk is of dat invloed moet worden toegekend aan enig ander kenmerk dat daarmede parallel 1oopt,"(Van der Wielen, 1960, pag. 282).

Men zou mogen aannemen dat de suggesties om deze doeltreffendheid te verhogen inmiddels verouderd zijn.

"Wat betreft inkrimping van de praktijk is uit een berekening gebleken dat blj terugbrengen van de praktijkgrootte tot maximal 2000 zielen, in plaats van ongeveer 5 minuten per contact tussen hulsarts en patiënt, 8,5 minut ter beschikking komt," (Van der Wielen, 1960, pag. 283).

Zoals verderop uit ons onderzoek zal blijken is de gemiddelde tijd per huisarts-patiëntcontact 7,4 minuten bij een prakt1jkgrootte rond de 2500 . Of de hiermee voorspelde toename van kwallteit van zorg en "gelegenheid tot studie en recreatie" ook ultgekomen zijn, valt in ons onderzoek niet na te gaan.

De relevantie van de tijdsdruk, al dan niet in relatie tot kwalltelt, wordt nog herhaldelijk als argument gebruikt voor vermindering van of verschuivingen in het takenpakket van de huisarts.

Het tijdsgebrek van huisartsen speelt ook in de studie van Jansen-Emmer (1958). Door de gerichtheid van dit onderzoek 
op de huisarts in relatie tot "het normale gezin" krijgt het totale pakket, de taakonderdelen en hun onderlinge verhoudingen meer aandacht.

"Naast de goede verzorging op somatisch gebied vonden wij de hiervoorbeschreven problematiek op andere gebieden, die evenzeer verzorging behoefden. Het kan niet gezegd worden dat de huisarts deze problematiek niet kende of er geen oog voor had. Zeer zeker niet. Maar bij de huidige wijze van werken is het hem onmogelijk in deze problematlek dieper door te dringen.

Het zou denkbaar zijn, dat aan deze lacunes tegemoet te komen zou zijn door de huisarts meer tijd te geven voor zijn patiënten. Dit zou ten dele een organisatorische, ten dele een financiële kwestie zijn.

Maar hiermee is zeker geen principiële oplossing gegeven. zeer zeker behoort het tot de taak van de huisarts de psychische en sociale omstandigheden van zijn patiënten te kennen. Het is zeer de vraag of het zijn taak is, on zich bijzonder met de matschappelijke omstandigheden van zijn patiënten bezit te houden," (Jansen, Emmer, 1958, pag. 72).

De discussie omtrent de inhoud van het takenpakket die wordt aangesneden, betreft een onderwerp waarover ruim 20 jaar later nog steeds de meningen verdeeld zijn.

Door Raupp (1972) wordt, los van morbiditeit, kwaliteit en inhoud van het takenpakket, bestudeerd of er samenhang te ontdekken valt tussen werkwijze van huisartsen enerzijds en kenmerken van zijn praktijk en persoon anderzijds. De door hem verzamelde kwantitatieve gegevens bij ongeveer 200 solistisch werkende huisartsen in Limburg, beschouwt hij als noodzakelijke gegevens bij discussies en mogelijk interventies in de kwaliteit van het huisartsenwerk. De variantie in werkwijze b1ijkt voor $50 \%$ te verklaren uit:

" - werklast (omvang van het medisch handelen)

- stad/platteland variabelen, en

- de tendens van het toepassen van moderne methoden voor praktijkvoering." (Raupp, 1972, pag. 94).

In termen van gemeten variabelen:

" - de praktijkgrootte

- de afstand tot het ziekenhuis of hiermee samenhangende variabelen 
- de nascholing van de huisarts de beroepsbeleving factor II

de leeftijd van de huisarts", (Raupp; 1972, pag. 81).

Zoals in het volgende hoofdstuk zal blijken, komen deze varlabelen nagenoeg allen terug in ons onderzoek.

Samenvattend:

De 11teratuur over onderzoek dat in Nederland in huisartspraktijken is gedaan, is zeer heterogeen van samenstelling. Voor zover deze voor ons onderzoek relevant geacht kan worden, is een beknopt overzicht gegeven aan de hand van een beperkt aantal studies, die leder op hun eigen terrein als kenmerkend kunnen worden beschouwd. Hieruit zijn enkele aanknopingspunten voor ons onderzoek genoemd.

Allereerst de betekenis van de tijdsdruk, waardoor de kwaliteit en doeltreffendheid van de hulpverlening door huisartsen in gevaar kan komen.

Vervolgens de discussie over de taakbreedte, toegespitst op de mate warin huisartsen psychosociale aspecten in hun patiëntenzorg betrekken.

Tenslotte de variabelen in de werkomgeving en de persoonskenmerken van de hulsarts, die voor een belangrijk deel verklarend zijn voor verschillen in werkwijze. Zowel door verschillen in aandachtsveld, als door een andere opzet en gebruikte meetinstrumenten, zijn vergelijkingen van resultaten met ons onderzoek nauwelijks mogelijk. Wel worden de drie genoemde aandachtspunten in de verdere uitwerking van dit onderzoek opgenomen.

\subsubsection{DELEN UTT HET WERK VAN DE HUISARTS}

Het onderzoek dat in Nederland is verricht naar de verwijscijfers, hun omvang, richting en de factoren die hierop van invloed zijn, is de meest omvangrijke hoeveelheid kwantitatleve informatie die omtrent de huifsartsgeneeskunde bekend is. (Uitgebrelde literaturlijsten over dit onderwerp zijn te vinden bij Van Es en Pylman, 1970; Bremer, 1964; Rop, Lamberts en Van Weel, 1979; Posthuma en Van der Zee, 1980). 
Een reden voor deze aandacht is, dat de verwijzing door de huisarts de introductiebrief is voor het geheel van gespecialiseerde voorzieningen die de hedendaagse gezondheidszorg kent. Deze "blanco cheque" leidt ertoe dat vrijwel alle medische mogelijkheden voor de patiënt gratis ter beschikking komen. Het ligt voor de hand dat - mede onder druk van de noodzakelijk geachte bezuinigingsvoornemens -, de aandacht van gezondheidszorg-onderzoekers en -beleidsmakers werd gericht op de aantallen verwijzingen die een huisarts uitschreef.

Een andere reden waarom - los van economische of bestuursmotieven - zoveel research op het verwijzen van huisartsen betrekking heeft, ligt in het relatief eenvoudig meetbaar zijn van de verwijzingen.

Niet alleen dat ziekenfondsorganisaties al geruime tijd een inmiddels geautomatiseerde centrale registratie bijhouden van alle verwijzingen ten behoeve van ziekenfondspatiënten, maar ook voor de onderzoeker zelf is het verzamelen van verwijsmateriaal relatief eenvoudig en kan bovendien als redelijk geldige outputmeting voor de zorgverlening door de huisarts worden gehanteerd. Bovendien kan deze outputindicator dienst doen als afhankelijk variabele in onderzoek, gericht op opsporing van relaties tussen vraag en aanbod in de gezondheidszorg. In de Nederlandse onderzoeksliteratuur wordt verwijzen door huisartsen met name geanalyseerd in de constructie van stroommodellen voor het gebruik dat gemaakt wordt van de verschillende echelons in de gezondheidszorg, (Rutten 1978).

Omdat wij ook het verwijzen naar andere hulpverleners als een van de functies van de huisarts beschouwen, zal ook in dit onderzoek de nodige aandacht hieraan worden besteed. Literatuur die in dit verband relevant wordt geacht, zal hierna - bij de bespreking van het tweede deel van de probleemstelling - aan de orde komen.

De literatuur omtrent het opstellen van categorieën en registratiesystemen gericht op het vastleggen van het probleem- en klachtenaanbod bij huisartsen, is hier minder relevant. Het is vermeldenswaard dat inspanningen op dit gebied, veelal beschrijvend van aard en uitgevoerd door huis- 
artsen, nog tot weinig uniformiteit hebben geleid, (Lamberts, 1979; Van der Horst, 1981). De belangrijke discussie omtrent opzet van en onderlinge verschillen tussen categorleën voor meting van probleemaanbod, klachtpresentatie en diagnosestelling is zeker nog niet ten einde, (Lamberts en Sloot, 1978). Mede ten gevolge hiervan zal een uniforme, in ledere huisartsenprakt 1 jk toegepaste gegevensverzameling van het werk dat huisartsen dagelijks verrichten, nog niet op korte termijn in te voeren zijn.

\subsubsection{DE VORM VAN DE HUISARTSENPRAKTIJK}

Op het gebled van samenwerkingsvormen warbij ook huisartsen betrokken zijn, kent Nederland sinds 1974 een zeer gevarieerde hoeveelheid literatuur. De overgrote meerderheid betreft beschouwingen, vermoedens, wensen en opinies omtrent de wenselijkheid of noodzaak om juist wel of niet tot bepaalde vormen van samenwerking te besluiten. De feitelijke ultvoering van samenwerking wordt in enkele gevallen kwantitatief geëvalueerd, waarbij satisfactie van patiënten en/of medewerkers als afhankelijk variabele functioneert, (Crebolder, Nijmegen, 1977).

Gegevens omtrent de betekenis van verschillende vormen van samenwerking tussen huisartsen onderling of met andere eerste echelon-werkers voor de inhoud van hun werk, zijn slechts zeer incidenteel verzameld, (Van Duuren en Hupkens, 1981). Gezlen echter het grote belang dat zowel de overheid als de beroepsorganen hechten aan samenwerking, moet men verwachten dat de invloed op het pakket van zorgverlening door huisartsen aanzienlijk moet zijn.

In 1970 werden 5 experimentele gezondheidszorgcentra in Nederland met steun van het Preventiefonds, gestart. Het gelijktijdig hiermee opgezette onderzoek wil veel meten, maar acht rendement onmeetbaar:

"Over onderzoek naar de vraag wat de waarde, het rendement of de kwalitelt van een gezondheidscentrum is in vergelijking met bestaande vormen van dienstverlening in de eerste $11 \mathrm{Jn}$, w11len we opmerken dat dit 0.1 . om de volgende redenen nog niet mogelijk $\mathbb{1}$ s. Ten eerste lopen de doelstellingen die men in de gezondheidszorg wil bereiken uiteen. Wil men na- 
gaan welke vorm van dienstverlening goedkoper is, dan moeten de resultaten van deze diensten vergelijkbaar zijn en dat is zelden het geval. Ons inziens zou een onderzoek naar het rendement plaats moeten vinden door middel van een vergelifking van de kosten van de verschillende "dienstenpakketten'," (De Boom, Van Duin, e.a. 1973).

Ondanks het uitblijven van kostenanalyses is in februari 1980 de centrale overheid er van overtuigd dat samenwerken in het eerste echelon ondersteund moet worden. "Op versche1dene plaatsen zijn deze contacten (tussen organisaties en werkers) reeds gestructureerd, waarbij gemeenten veelal steun verlenen. Deze ontwikkelingen dragen bij tot een versterking van de eerstelijns-gezondheidszorg. Zij zullen er ook toe leiden dat het inzicht gemeen goed wordt dat samenwerking in enigerlei vorm noodzakelijk is, hetgeen ook zal resulteren in aanpassing van de werkwijze en wijze van ondersteuning binnen de betrokken instellingen. Het spreekt voor zich dat de overheid de hierboven aangegeven ontwikkelingen zal stimuleren en bevorderen," (Schets van de eerstelijns-gezondheidszorg, Tweede Kamer, zitting 1979-1980, pag. 38).

Over de samenwerking met andere hulpverleners buiten het eerste echelon is de overheid minder zeker.

"Het is van belang, dat in het kader van de regionalisatie aan deze vraagstukken betreffende de samenwerking grote aandacht wordt besteed. Gewenst is een goede inventarisatie en analyse van de bestaande vormen van samenwerking, om daarop overleg over verbeteringen te kunnen baseren," (Schets, pag. 39). Het weinige onderzoek dat verricht is in Nederland betreffende de relatie huisarts-specialist geeft echter duidelijk aan dat beiden het belang van intensievere samenwerking inzien. In het bijzonder worden versterking en uitbreiding van diagnostische capaciteit en faciliteiten van de huisarts bepleit met een verwachte daling van het aantal verwijzingen, (De Melker, 1980).

"Het belangrijkste lijkt ons dat door een toenemend zelfvertrouwen vanwege een betere opleiding en een goed gebruik van diagnostische hulpmethodieken èn door een mentaliteitsverandering - in éên woord: door een herwaardering - de huisarts weer meer zelf ter hand neemt en zijn taak als cen- 
trale figuur in de volksgezondheid waarmakt. Hetgeen ondermeer zal inhouden, dat hij pas "verwijst" als de patiënt er beter van wordt", (Puylaert, 1978).

De oprichting door de regering van diagnostische centra die naast de huisartsenlaboratoria deze ultbrefding van de diagnostische capacitelt in het takenpakket van de huisarts mogelijk moeten maken, is een in het tweede deel van onze probleemstelling nog terugkerende factor.

Als afzonderl1jk hulpverleningsgebled warmee de huisartsen bij hun taakuitoefening in annraking komen, moet nog genoemd worden de geestelijke gezondheidszorg. In het bijzonder de hierin functionerende bureaus voor ambulante geestelijke gezondheidszorg lijken vele verbindingen te hebben met het takenpakket van de huisarts. Onderzoek wijst echter uit dat deze verwachting niet door de feiten wordt ondersteund.

"... na de matschappelijk werkers hebben zij (: de huisartsen) in de eerste lijn de hoogste verwijsfrequentie naar deze bureaus. Op het totaal aantal contacten en verwijzingen is deze frequentie echter praktisch te verwaarlozen. Ter 11lustratie: ongeveer $70 \%$ van de huisartsen zegt dagelijks in contact te komen met psychische problematiek. Toch heeft van hen slechts $12 \%$ gedurende een periode van vijf maanden meer dan één cliënt naar de S.P.D. verwezen. Voor het bureau voor levens- en gezinsvragen is dit $15 \%$. Het M.0.B. springt eruit met $50 \%$, "(Hirs en Hosman, 1973)".

Waaraan dit geringe percentage verwijzingen naar de ambulante geestelijke gezondheldszorg moet worden toegeschreven is niet bekend. Mogelijk bestaat er een redelijk grote onbekendheld met de Inhoud en methode van hulpverlening in deze zorgsector.

Psychische problematiek van patienten wordt wellswaar door de huisarts onderkend, maar vrijwel altijd door hemzelf behandeld. Een voor de hand 1iggende canclusie is, dat op het terreln van de geestelijke gezondheidszorg in relatie tot het takenpakket van de huisarts meer behoefte is aan kennisvermeerdering bij de huisarts dan aan organisatorische versterking van de eerste $1 i j n$ op dit punt.

De mate van "zelfdoen, consulteren of verwijzen", is zeker voor de psychische problematiek nog een discussiepunt bij de opvattingen over het geheel van werkzaamheden die door huisartsen moeten worden verricht. 
Samenvattend:

De literatuur op het terrein van vorm- en structuuraspecten van. het werkgebied van huisartsen bevat voornamelijk een grote hoeveelheid beschouwingen en een gering aantal onderzoekingen betreffende samenwerken van huisartsen met andere disciplines. In het bijzonder de samenwerking binnen het eerste echelon wordt vrijwel zonder discussie als een versterking gezien, met duidelijke consequenties voor het takenpakket van de huisarts.

Samenwerking met andere dan eerste echelon-werkers heeft minder aandacht. Vrijwel uitsluitend is hier de relatie huisarts-specialist in het geding, warbij het verwijscijfer van huisartsen functioneert als de meest tastbare indicator voor de mate van effectiviteit van deze samenwerking. Als meest genoemde en vrijwel onomstreden vorm van versterking van de huisartsenpositie wordt het ultbreiden van de diagnostische mogelijkheden voor de huisarts gezien. De veronderstelling hierbij is dat niet alleen de inhoud van het takenpakket van de huisarts in zijn totaliteit aan kwaliteit wint, maar bovendien dat de intake-functie die de huisarts inneemt in de gezondheidszorg verbeterd kan worden.

2.3. PROBLEEMSTELLING EN LITERATUUR BIJ VERKLARING VAN VERSCHILLEN IN FUNCTIE-UITOEFENING

De literatuur bij het tweede deel van de probleemstelling is te verdelen in twee gebieden:

a) vraag- en aanbodrelaties in de gezondheidszorg: par. 2.3.1.;

b) verwijscijfers van huisartsen in relatie tot structurele en persoonsvariabelen: par. 2.3.2.

Voor onze probleemstelling is voornamelijk van belang de literatuur betreffende de autonome werking van het aanbod op de vraag in de gezondheldszorg. Zoals uit het laatste deel van dit hoofdstuk nog zal blijken, is op veronderstellingen hieromtrent, het tweede deel van de probleemstelling gebaseerd.

De op gang komende uitgebreide onderzoeksverslagen betreffende het verwijscijfer van hulsartsen en de hierop inwerkende factoren zullen slechts kort worden aangestipt. 
Elders zljn overzichten van de desbetreffende literatuur voldoende uitgewerkt en beschikbaar. Bovendien speelt het verwijzen door huisartsen in ons onderzoek een andere rol en is op minder vaak voorkomende wijze geindiceerd.

\subsubsection{VRAAG EN AANBOD}

De - voornamelijk buitenlandse - literatuur betreffende vraag en aanbod in de gezondheidszorg is terug te voeren op de discussie ontrent "needs" en "demands". Over deze begrippen $z i j n$ onvangrijke verhandelingen gehouden waarin getracht wordt klaarheld te verschaffen in de zeer grote hoeveelheid definities.

De basisgedachte is dat de behoefte aan hulp ten behoeve van de gezondheidsbevordering en/of therstel in principe onbegrensd 1s. Het aanbod van hulp op grond van wat volgens deskundigen nodig en mogelijk is, bepaalt vervolgens welke inhoud en onvang van gezondheidszorg feitelijk verstrekt wordt.

Een meer precieze omschrijving geeft Jeffers, (Jeffers, 1971) "Need for medical services: that quantity of medical services which expert medical opinion belleves ought to be consumed over a relevant time period in order for its members to remain or become as "healthy" as is permitted by existing medical knowledge". "Population's wants for medical services: that quantity of medical services which its members feel they ought to consume over a relevant time period based on their own psychic perceptions of their health needs"

"Demand for medical services:

A multivariate functional relationship between the quantities of medical services that its members desire to consume over a relevant time perlod at given levels of prices of goods and services, financial resources, size and psychological wants of the population as reflected by consumer tastes and preferences for (al1) goods and services".

In welke mate de "demands" volledig bepalend zijn voor het feltelijk gerealiseerde zorgniveau, is afhankelijk van de werking van het vrije markt-mechanisme. Beperkingen bestaan niet alleen op het vlak van prijsvorming en betalingsregelingen, maar ook op het bezitten van voldoende informatie 
waardoor voor patiënten eigen, vrije keuzes mogelijk worden. Een nadere uitwerking van de wijze waarop de "demands" worden gerealiseerd geeft Feldstein (1974), door de rol te benadrukken die de arts speelt als "agent" bil de totstandkoming van beslissingen over de feitelijk geconsumeerde zorg. Deze indeling, ook door Posthuma en Van der Zee (1980) overgenomen, geeft de volgende typologie:

I. zorg op initiatief van de patiënt (de "echte" vraag naar gezondheidszorg);

II. zorg op initiatief van de ene arts en verschaft door een andere arts;

III. zorg op initiatief van de arts en door hemzelf verschaft.

Het basismechanisme is de transformatie van de vraag naar gezondheidszorg door de arts als "agent", tot zorg van type II of III.

Belangrijk in dit verband is, dat verklaringen voor de omvang van de feittelifke gerealiseerde zorg, gezocht moeten worden zowel aan de kant van de echte vraag (type I), als bij de getransformeerde vraag (type II en III). In termen van deze typologie, kan ons onderzoek worden aangeduid als gericht op verklaring van de getransformeerde vraag. We veronderstellen dat de huisarts een eigen invloed heeft op de omvang en de inhoud van de door hem verstrekte zorg. De mate waarin deze autonomie van de arts wordt beinvloed door omstandigheden in de werksituatie, of het gevolg is van zijn taakopvatting als huisarts, zal in ons onderzoek nader worden aangeduid.

De belangrijke rol van de arts in het beslissingsproces met betrekkling tot de geboden zorg wordt ook door A. Smith (1976, pag. 56) beschreven:

"The dominating feature of the health market is the consumers lack of knowledge. They do not know their risks of 111-health. They do not nornally know what preclse services they want to buy, the prospects of benefiting from them or whether they have had good or bad health serwices after they have bought them".

Het zijn de bemiddelende overheid en ziekenfondsen, die samen met de artsen als verstrekkers, bepalen welke zorg wel en niet geboden wordt, tegen welke prijs en in welke omvang. 
Uitgaande van wat volgens de beroepsbeoefenaren nodig is, wordt in overleg met de verzekeraars en de overheid vastgesteld wat de patiënt aangeboden zal worden. Vrije keuze voor deze is mogelijk binnen de geringe speelruimte, die hem gelaten wordt door professionals en overheid. Het eigen initlatief bestaat nog slechts uit het al dan niet accepteren van het totale pakket geboden zorg. Bovendien is ten gevolge van toenemende verantwoordelijkheden van de overheld voor het collectieve welzijn, ook deze keuze van wel of niet consumeren, in vele gevallen niet meer mogelijk. Vele collectieve voorzleningen klezen bijvoorbeeld als sluis voor inen/of ultvoering in hun systeem het medische screeningspakket van keuringen en bepalingen, met voor de patiënt vèrstrekkende gevolgen.

De betekents van de discussie omtrent vraag- en aanbod-verhoudingen in de gezondheidszorg is meer dan alleen van theoretisch belang. Zo is bijvoorbeeld voor een systeem van manpower-planning in de gezondheidszorg informatie nodig over de behoefte aan zorgverlening bij de bevolking, om deze te kunnen relateren aan de aanwezige en benodigde mankracht. Een hieruit resulterende discrepantie zou idealiter bepalend moeten zijn voor de planning van de mankracht.

De verwevenheid echter van "echte" vraag en getransformeerde vraag leidt er toe, dat in de praktijk volstaan wordt met meting van de feitelljk gerealiseerde zorg en bepaling van de hlervoor noodzakelijke mankracht, uitgedrukt in artsenratio per bevolkingseenheid. Veranderingen in deze ratio worden nagestreefd wanneer een ander, meer ultgebreid aanbod van zorg door artsen noodzakelijk wordt geacht, de werkgelegenheld voor artsen in gevaar komt, of de financieel-economische situatie sterk verandert.

Nederland heeft na zijn laatste "Commissie Artsenbehoefte" (1969) lange tijd een zekere rust gekend in het "plannen" van mankracht. Deze comissie achtte een artsendichtheid van 1,4 op de 1000 inwoners redelijk en verwachtte dat met dit aantal er "geen aanwijzingen zouden zijn dat.... de gezondheidszorg zich op onaanvaardbaar niveau zou bewegen", (pag. 22). In 1980 echter laalde de discussie weer op. De dichtheid van 1,6 in 1982 blijkt voor de een onaanvaardbaar, voor de ander redelijk; n.l. afhankelijk van welke gezondheids- 
zorg men wil aanbieden en in welke mate, (Greep, 1980). Een huisartspraktijk van 2000 lijkt het absolute maximum in 1987, terwij1 de "initiatiefgroep praktijkverkleining" in 1979 reeds voorrekent dat zo spoedig mogelijk praktijkverkleining voor huisartsen tot 2000 moet worden toegepast als verantwoord beleid, zowel uit kostenoogpunt als ten behoeve van de kwaliteitsverbetering van de zorg, (Van Praag, 1980; Cromme, 1980).

Al deze discussies gaan uiteraard uit van een kwalitatief verantwoord niveau van zorgverlening. Op geen enkel moment is de zogenaamde "echte vraag" naar zorg in het geding. Alleen als een soort sluitpost: bij alle mogelijke dichtheden, reconstructies, inkrimpingen en overschotten wordt telkens gesteld dat aan de "echte" vraag vanuit de bevolking op verantwoorde wijze is tegemoet gekomen.

Het is mogelijk dat de in 1982 geinstalleerde "commissie Vorst" nieuwe argumenten in de discussie zal aandragen. De opdracht aan deze commissie om het totale personeel dat werkzaam is in de gezondheidszorg, te betrekken in de planning, gevoegd bij de alom aanwezige noodzaak tot bezuinigen, kan tot nieuwe uitgangspunten leiden.

Samenvattend:

De relatie tussen vraag en aanbod in de gezondheidszorg is van betekenis voor de analyse van de feitelijk verstrekte zorg. Door de arts te zien als "agent" die in een zekere mate van autonomie bepalt welke hulpverlening aan de patiënt wordt geboden, richt de aandacht zich vervolgens op die factoren, die op hun beurt de arts beinvloeden bij zijn functievervulling.

\subsubsection{VERWIJSCIJFERS}

De literatuur betreffende verwijscijfers van hulsartsen is, zoals reeds opgemerkt, hier minder relevant. Het verwijzen door een huisarts naar andere hulpverleners, met name het $2 \mathrm{e}$ echelon, wordt in dit onderzoek beschouwd als één van de functies die huisartsen vervullen. De uitgebreide literatuur omtrent de juiste vorm van meting van het verwijscijfer en de invloeden die hierop werkzaam zijn vanuit persoons- en werkkenmerken van huisartsen, zal dan ook slechts kort worden aangeduid. 
Nadat in de zestiger jaren het onderzoek naar verwijscijfers van huisartsen in Nederland is gestart, (Van Es en Pijlman, 1970; Bremer, 1964) komt de grote belangstelling van onderzoekers na het verschijnen van het zogenaamde macro-rekenmode1. Reeds in het interim-rapport, uitgebracht door de werkgroep van economen uit Leiden: "Het ziekenhuis in de Gezondheldszorg" wordt een modelmatige relatie gelegd tussen huisartsendichtheid en bedbezetting in ziekenhuizen. Meer specifiek uitgewerkt in de analyse van het verwijscijfer verschijinen vervolgens onderzoeksresultaten, die de relatie tussen hulsartsendichtheld en hoogte van verwijscijfer kwantitatief trachten te bepalen, (Rutten en Van der Gaag, 1977; Rutten, 1978; Posthuma en Van der Zee, 1978). De discussies over de methodologische julstheid van gevolgde rekenprocedures doen echter steeds meer twijfel ontstaan over de betekents die eraan gehecht moet worden. Bovendien verschillen de uitkomsten nogal sterk:

"Van Praag en Van der Gaag een daling, Posthuma en Van der Zee een st1jgling en Rutten geen verband" (tussen hulsartsendichtheid en verwijscijfer), (Posthuma en Van der Zee, 1980, pag. 60). De eindconclusie van deze onderzoekers, gebaseerd op een tijdreeksanalyse van cijfermateriaal over Nederland als geheel genomen, kan in meerdere opzichten als een verrassend compromis worden beschouwd.

"Hoewel de resultaten van de tijdreeksanalyse niet geheel conform de verwachtingen zijn, ......... willen wij onze hypothese dat het vexband tussen (gemiddeld) praktijkgrootte en het bruto ziekenfondsverwijscijfer met een bergparabool kan worden weergegeven als een serieus alternatief voor een 1inealre relatie blijven beschouwen," (Posthuma en Van der Zee, 1980, pag. 66). Niet alleen de praktijkgrootte is van betekenis bij de verklaring van verschillen in verwijscijfers. Onder verwijzing naar de door hem verzamelde literatuur volgen we Verhoeff (1979) in zijn groepering wan factoren die van invloed zijn op de hoogte van het verwijscijfer. "a) het jaar warop de gegevens van het onderzoek betrekking hebben;

b) de invloed van de urbanisatiegraad;

c) de invloed van de wijze warop de patienten verzekerd zijn;

d) de organisatievorm waarin de huisarts zijn praktijk uitoefent; 
e) de praktijkgrootte van de huisarts;

f) apotheekhoudende - niet-apotheekhoudende huisarts;

g) diagnostische faciliteiten voor de huisarts;

h) het initiatief tot verwijzing".

In de analysefase van dit onderzoek zullen we nog terug komen op enkele van de hierboven gegroepeerde variabelen, omdat we aannemen dat indien deze genoemde factoren het verwijscijfer beïnvloeden, ze ook wel van betekenis zullen zijn bij de verklaring van de variantie in andere functiegebieden van de huisarts.

Samenvattend:

Bij de bestudering van verwijscijfers zijn in verschillende onderzoeken in Nederland factoren gevonden, die bijdragen aan de verklaring van gevonden verschillen in hoeveelheid verwijzingen per huisarts. Voorbijgaande aan de zeer specifieke, vaak econometrische uitwerking van de relatie tussen praktijkomvang en verwijsgedrag, menen we toch dat kenmerken van de praktijk, en van de persoon van de huisarts - die van betekenis blijken in de analyse van verwijscljfers - ook betrokken moeten worden in de verklaring van de variantie bij de uitoefening van het totale takenpakket van de huisarts. 
HOOFDSTUK 3

OPERATIONALISERING

\subsection{FUNCTIES VAN HUISARTSEN}

De operationalisering van functies die hulsartsen vervullen, is in de geraadpleegde literatuur of weinig gedifferentleerd òf zeer speciflek op én bepaald doel gericht.

Voorbeelden van het eerste type treffen we aan bij outputmeting ten behoeve van produktiefuncties. Kimbell en Lorant (1977) nemen als outputmaten: bruto-inkomsten per jaar, jaarlijks aantal patiëntencontacten, en consulten in de spreekkamer. U. Reinhardt (1972) volgt deze indicering. Gesplitst naar de werkplek onderschelden Donaldson en London (1971) de doktersactiviteiten in vijf categorieën: patiëntenzorg, wachttijd, administratie, voorbereidingen en reistijd.

Wanneer naast de meer beschrijvende aanduidingen bovendien de handelingen worden geregistreerd, die met de aard van de klacht samenhangen, ontstaan zeer uitgebrelde lijsten. Het specifieke doel waartoe deze gebruikt worden, is de analyse van Eén praktijk, (Marsh en Kain-Cande11, 1976; Marsh en Mc Nay, 1974; Wolfe e.a., 1967) of het testen van specifieke meetprocedures, (Kovner, 1969). Een voorbeeld is de I.M.P. (identiflable medical procedure)-methode, die geheel vanuit de patiënt-kaarten kan worden samengesteld. Meer bekend is de "task inventory"-werkwijze, ondermeer door Jacoby en Kniding (1975) gebrulkt om de interne taakverdeling te bestuderen in een aantal praktijken die primaire, ambulante zorg verlenen. In deze analyse worden 650 activitelten en hun tijdsduur vastgelegd. De grote hoeveelheid aldus verkregen gegevens wordt benut voor achteraf geformuleerde (deel)vragen.

Meer gericht tenslotte, verzamelen Holmes e.a., (1978), hun materiaal, warbij zowel de artsactiviteiten als de statusgegevens van de patiënt worden gebruikt on de vraag te onderzoeken: in welke mate voldoet de "primary care" aan de 
vaak gestelde criteria van:

"continuous, coördinated, comprehensive family-centered", (Holmes e.a. 1978, pag. 231).

Een vergelijkbare aanpak voor operationalisering wordt ten behoeve van dit onderzoek gekozen. Om de plaats van de huisarts in de gezondheidszorg te beschrijven, gaan we ult van de volgende schematische aanduiding van functies, (Navarro, 1971; White, 1967).

Figuur 2: Functies van de huisarts in de gezondheidszorg

eerste echelon

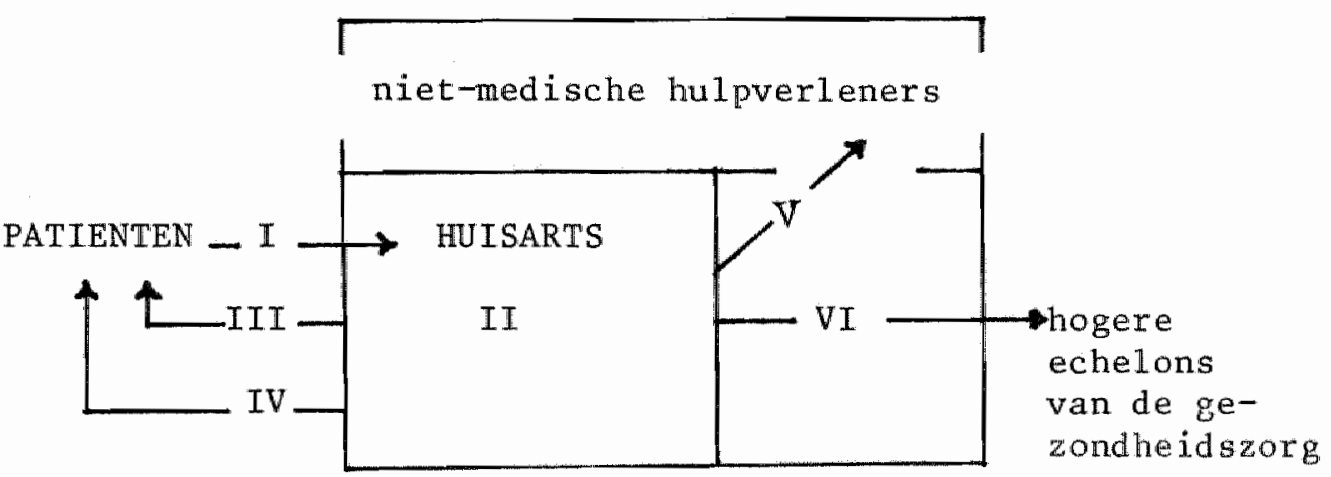

I. Intake: diagnostiek

II. Behandeling door de huisarts zelf: theraple

III. Begeleiding door de huisarts

IV. Preventie, secundair (: vanuit bestaande symptomen, klachten) en primalr (: ter voorkoming van klachten)

v. Verwijzing naar niet-medische hulpverleners, al dan niet in het eerste echelon (: maatschappelijk werk e.d.)

VI. Verwijzing naar 'hogere' medische echelons. 
Als observatiecategorieën voor deze functies zijn de volgende activiteiten gespecificeerd, deels samenvaliend met de taakomschrijving door de Commissie Takenpakket, (L.H.V. 1976).

FUNCTIE

I. DIAGNOSTIEK

II. THERAPIE

III. BEGELEIDING

IV. PREVENTIE
ACTIVITEITEN

- anamese

- lichamelijk onderzoek

- eigen laboratorium-onderzoek

- uitbesteed laboratorium-onderzoek

- uitbestede diagnostische bepalingen

- medicatie

- advies

- gesprekken

- handelingen (kleine chirurgie)

- partus

- curatieve zorg voor chronisch zieken

- follow-up van behandelingen

- toelichtend, additioneel informatieverstrekken

- geboorteregeling

- prenatale zorg

- G.V.O.

- vaccinatie

- periodiek geneeskundig onderzoek

- surveillance van risicopatiënten 
V. VERWIJZING BUTTEN

VI. VERWIJZING BINNEN DE GEZONDHEIDSZORG
- verwijzing naar niet-medische hulpverleners

- inlichtingen vragen aan nietmedische hulpverleners

- inlichtingen geven aan nietmedische hulpverleners

- diagnostische verwijzing

- therapeutische verwijzing

- consult vragen

- consult geven

Naast de aldus geoperationaliseerde functies, worden nog werkzaamheden verricht die het gevolg zijn van noodzakelijke voorwaarden bij de praktijkvoering.

Bovendien verrichten huisartsen nog werk dat niet noodzakelijk samenhangt met hun positie als huisarts, maar het gevolg is van hun bevoegdheid tot het uitoefenen van de geneeskunst.

Tenslotte zal een aantal activiteiten moeten worden opgenomen in de observatielijst, dat samenhangt met de persoonlijke- en/of werkkenmerken. De in hoofdstuk 4 nog te bespreken methoden van dataverzameling makt een totale dekking van alle voorkomende werkzaamheden noodzakelijk.

De hierboven aangegeven 6 functies met bijbehorende activiteiten worden daarom aangevuld met:

VII. CONDITIES

VIII. ACTIVITEITEN ALS ARTS
- praktijkorganisatie

- registratie + administratie

- onderwijs-geven

- bijscholing

- samenwerking

- keuringen

- medisch adviseurschap

- stellen van medische indicaties

- groepsbegeleiding

- bestuursactiviteiten

- andere artsenactiviteiten 
IX. APOTHEEKWERKZAAMHEDEN

X. REST

- reistijd

- telefoon

- sociaal contact

- privé

Een verantwoording van de gekozen indeling op grond van speciflek inhoudelijke overwegingen wordt gegeven in de publikatie van Van Zutphen, (1983).

\subsection{TAAKOPVATTING}

Voor de meting van de breedte in taakopvatting van huisartsen is gezocht naar die onderdelen in de taakomschrijving, waarover binnen de beroepsgroep meningsverschillen bestaan of ze al dan niet tot het uit te voeren takempakket behoren. over leder discussieonderwerp werd een positief en een negatief geformuleerde vraag in een vragenlijst opgenomen. Deze werkwijze leidt enerzijds tot een meetinstrument van de taakopvatting met een zo groot mogelijk discriminerend vermogen. Anderzijds trachten we door deze vorm van perceptiemeting een relatie aan te brengen met de ontwikkeling in het proces van professionalisering. De wijze waarop de breedte van het werkterrein die in een normatieve taakstelling is vervat, wordt afgegrensd ten opzichte van andere beroepsgroepen is kenmerkend voor de ontwikkelingsfase van een beroep.

".... an ideological basis will affect both the perception of "problems" in dealing with the environment as well as the categorization of those dealings into specific activities.

... In this way, the world of objective problems is invariably conceptualized and ultimately dealth with according to a prevalilng division of licenses among populations," (Luhman, 1971, pag. 62). Over de discussiepunten in de taakstelling en de afbakening naar andere beroepsgroepen, hebben eind 1978 enkele gesprekken platsgevonden met de Commissie "Takenpakket" van de L.H.V. Per functie werden onderwerpen verzameld die volgens deze groep huisartsen te beschouwen zijn als indicatief voor de verschillende meningen omtrent de breedte van de huisartsen-takk. 
Naast de breedte in taakopvatting per functie, zijn vragen opgesteld met behulp waarvan het gewenste niveau van het medisch-somatisch handelen kon worden aangegeven voor de functies: diagnotiek en therapie.

Tenslotte werd per functie gevraagd naar de tijdsdruk en de ondersteunende werking van aanwezige gezondheidszorgvoorzieningen. Hierdoor kan een koppeling gellegd worden tussen de takkopvatting en de structuur van de gezondheidszorg. Aan de vragenlijst werden bovendien vragen toegevoegd betreffende leeftijd, afstudeerdatum en -tijdstip. ook zijn vragen opgenomen omtrent een antal objectieve praktijkkenmerken en het patiëntenbestand.

\subsection{STRUCTUURKENMERKEN VAN DE GEZONDHEIDSZORG}

Voortvloeiende uit het tweede deel van de probleemstelling en onder verwijzing naar de daarbij besproken literatuur $z i j n$ gegevens noodzakelijk betreffende de structurele voorzieningen van de gezondheidszorg.

De volgende indeling is hierbij gemaakt:

a) objectieve registratie van structurkenmerken

- ten aanzien van de huisartspraktijk waarin de taakmeting plaatsvindt: door middel van vragen in de vragenlijst (zie 3.2.)

- ten aanzien van de voorzieningen in het tweede echelon werd het aantal aanwezige ziekenhuizen geregistreerd per gemeente warin de te observeren praktijk gelegen is, alsmede de aan deze ziekenhuizen toe te kennen functie-classificatie;

b) subjectieve gegevens betreffende gebruik en mogelijk nut van een groot aantal voorzieningen, zoals dit wordt gewaardeerd door de huisarts.

De redenering achter het meten van structuurkenmerken met behulp van het subjectief weergegeven gebruik en nut is de volgende:

De aanwezigheid alleen van voorzieningen, anders dan het ziekenhuis, geeft nog geen indicatie over de mate warin deze "echt bestaan" voor de huisarts. Omgekeerd is het zo dat "gebruik maken van", als een vrij betrouwbare indicator 
moet worden beschouwd van de "aanwezlgheid". Bij algemene zlekenhuizen kan deze redenering ook wel opgaan, maar verwordt tot trivialiteit. De huisarts die geen gebruik maakt van het algemeen ziekenhuis, vervult zijn "verwijsfunctie" niet en moet in het Nederlandse gezondheidszorgsysteem op zijn zachtst gezegd tot de hoge uitzonderingen gerekend worden! De huisarts die geen gebruik maakt van het plaatselijke C.A.D. (Consultatlebureau voor Alcohol en Drugs) of H.A.L. (het Huisartsenlaboratorium) kan zeer wèl functioneren, maar heeft misschien een andere therapeutische c.q. diagnostische taakopvatting dan zijn collegae, die wel veelvuldig de genoemde woorzieningen gebruiken en het nog nuttig vinden bovendien. (Voor een complete weergave van de vragenlijst: zie bijlage 1 ).

Omdat de vragenlijst niet alleen gebruikt werd bij de onderzoeksgroep van huisartsen samengesteld ten behoeve van de functie-analyse, maar tevens bij een als representatief geldende steekproef van Nederlandse huisartsen, (zie hoofdstuk 4) werden aan de vragenlijst nog toegevoegd:

- Attitudevragen betreffende:

- arts-patiënt-verhouding

- werksatisfactie

- Voor de L.H.V. relevante vragen betreffende: waarneming; nascholing; toetsing; medicatlebewaking, prescriptie en vestigingsbeleid. 


\subsection{DEMOGRAFISCHE KEMMERKEN}

De demografische kenmerken die worden gehanteerd, vervullen in dit anderzoek de rol van indicator voor de patiënten. De volgende gegevens werden verzameld per gemeente waarin de huisartspraktijk was gevestigd:

- Leeftjdsverdeling volgens CBS-classificatie, gespecificeerd naar geslacht; $(1-1-1979)$

- beroepsniveau, opleiding en inkomen volgens CBS-codificatie, gebruikt in de volkstelling van 1972;

- urbanisatiegraad van de gemeente per 1-1-1979.

De gegevens zijn verzameld op gemeenteniveau, als gevolg van het ontbreken van de gewenste cijfers per praktijk. Men mag zeker aannemen dat in gemeenten met minder dan 3000 à 4000 inwoners de daar gevestigde huisarts een praktijkpopulatie heeft, die qua opbouw en samenstelling niet sterk zal afwijken van de hele gemeente. In grotere gemeenten is deze aanname niet zonder meer acceptabel. Over de wijze waarop de patiënt-recrutering wèl tot stand komt - in relatie tot bijvoorbeeld persoonskenmerken van de huisarts - is te weinig bekend om hierop gebaseerd, verantwoorde correcties in de demografische gemeentekenmerken te baseren. We nemen aan dat de verdeling van verschillende patlëntcategorieën over de aanwezige huisartsen min of meer a-select verloopt.

Samenvattend:

De te registreren functies van huisartsen zijn geoperationallseerd in activiteiten, met behulp waarvan de werkzaamheden van huisartsen kunnen worden vastgelegd.

De breedte van de takopvatting is geindiceerd met behulp van "discutabele" onderdelen in het takenpakket van huisartsen, gekozen in overleg met de hiervoor genoemde commissie van de L.H.V. De structuur van de gezondheidszorg is enerzijds direct gemeten op praktijkniveau en gemeenteniveau, anderzljds aan de hand van het door artsen gemaakte gebruik van ondersteunende voorzleningen. Demografische kenmerken tenslotte zijn geregistreerd op gemeentenlveau, onder aanname van niet te grote afwijkingen tussen populatieopbouw van de huisartsenpraktijk en die van de gemeente. 
HOOFDSTUK 4

ONDERZOEKSOPZET

\subsection{METHODE}

De meest ideale onderzoeksvorm ten behoeve van de probleemstelling is longitudinaal onderzoek. Het is immers duidelijk dat niet alleen de uitoefening, maar ook de perceptie van het takenpakket van huisartsen geen vaststaand gegeven is. Het registreren van feitelijke ontwikkelingen hierin met behulp van empirisch materiaal is meer dan wenselijk. Bovendien blijft het concluderen tot causale verbanden op grond van éenmalig geconstateerde samenhang een hachelijke zaak. Echter, zoals zo vaak, is ook nu weer het aantal praktische en technische problemen bij de opzet van het vereiste longitudinale onderzoek te groot om het te realiseren. Bovendien komt als extra moeilijkheid hierbij dat voor de meting van de functies en taakopvattingen van huisartsen allereerst meetinstrumenten ontwikkeld moeten worden. Hierbij kan vrijwel geen gebruik gemaakt worden van reeds geteste schalen of technieken. Het onderzoek bezit alleen al hierdoor een hoofdzakelijk exploratief karakter. De resultaten en interpretaties betreffende samenhangen tussen structuurvariabelen, taakperceptie en taakuitoefening, moeten dan ook met de grootst mogelijke voorzichtigheid gehanteerd worden.

\subsection{WIJZE VAN GEGEVENSVERZZAMELING}

Deze verschilt per variabelengroep:

a) structuurkenmerken van de gezondheidszorg: zowel objectieve registratie van aanwezige voorzieningen, als door huisartsen opgegeven praktijkgegevens;

b) demografische en economische kenmerken: gegevens van het C.B.S.; 
c) perceptle van taken: gegevens verzameld met betrekking tot een door huisartsen zelf in te vullen vragenlijst;

d) functies en taken wan de huisarts: gegevens verzameld door middel van observaties.

De keuze voor obserwatie vergt enige toelichting. De argumenten die aan deze keuze ten grondslag liggen zijn zowel van praktische als methodische aard.

Het verzamelen van gegevens omtrent de taakuitoefening door daarover aan de huisartsen vragen te stellen, stuit op het praktische bezwar van de extra tijdbelasting, die hiermee gemoeld is. Of men nu na afloop van iedere dag of week, of na leder consult, vraagt om te noteren wat er heeft plaatsgevonden, in alle gevallen wordt de huisarts extra belast en zijn motivatie om an het onderzoek deel te nemen zal hierdoor worden beinvloed.

Een bezwaat van doorslaggevende betekenis tegen het door hulsartsen laten registreren van eigen activiteiten, is de geringe betrouwbaarheid. Tussen de resultaten verkregen door observatie en die door huisartsen zelf geregistreerd, kunnen zeer grote verschillen bestaan, (Nelson e.a., 1975). Aan de rapportage van deze studie ontlenen we de in figuur 4 gegeven indeling van methoden die ter beschikking staan bij een onderzoek naar taakuitoefening.

Uit de vergelijking van de twee onderstreepte methoden, ultgevoerd bij een groep van 13 artsen, trekken de onderzoekers de volgende conclusie:

"...that agreement is insufficlent between task data obtalned by the two different methods to conclude that one method is substitutable for the other. The findings suggest that the major source of disagreement is neither intraobserver error nor variation in task observability but the tendency of role incumbents to overestimate how often they perform tasks and how long it takes to perform them.

... an impartial observer recording events as they happen is $11 k e 1 y$ to be more accurate than a job incumbent reporting on himself retrospectively, (Nelson e.a., 1975, pag. 113).

Gelljktijdig met de keuze voor observatie is tevens besloten deze uit te voeren als continue registratie. Er behoeft geen "time-sampling" te worden toegepast, omdat het interval dat 


\section{Figuur 4: Techniques for measuring task performance}

WHEN :

SELF

OTHER

a) observer follows job incumbents and records data as tasks are

b) job incumbent is followed by camera and his tasks are videotaped. a) job incumbents fill out task inventories periodically.

b) job incumbents are interviewed concerning their task performance

a) supervisor complets taskinventory

b) trained observer follows job incumbent, then completes task inventory

c) interviewer with supervisor

(Brom: Nelson, 1975, pag. 106). 
in ons onderzoek is gekozen (zie hoofdstuk 4.) dusdanig klein is, namelijk $10 \mathrm{sec}$, dat geen sprake is van zogenaamde multimomentopnamen zoals gehanteerd door Blokland-Kihler (1974). Wit het door ons uitgevoerde testonderzoek bleek dat handelingseenheden die minder dan 20 seconden duurden, niet zinvol te benoemen waren in het door ons gehanteerde categorieënstelsel.

Het observeren vergt observatoren, die in staat zijn de categorieën die door de onderzoeker zijn opgesteld, te verbinden met waargenomen handelingen. De interpretatie die de observator hierbij moet geven bleek bij ons categorieënstelsel dermate specifiek te zijn, dat we besloten om deze door getrainde artsen te laten uitvoeren. Bovendien wordt door het inschakelen van arts-observatoren de acceptatie bij de te observeren huisarts en patiënt groter.

Om de betrouwbaarheid en geldigheid van het meetinstrument voor de taakopvatting te vergroten is naast de groep huisartsen waarop de functie-analyse is uitgevoerd, tevens een representatieve steekproef van Nederlandse huisartsen samengesteld. Aan dezen werd alleen de vragenlijst voorgelegd in de vorm van een schriftelijke enquête. De resultaten van deze enquête worden met name gebruikt bij de schaalconstructie van "taakbreed te".

\subsection{MEETNIVEAU}

Het meetniveau verschilt per groep variabelen. De activiteiten en taakopvatting zijn gemeten op individueel niveau; praktijk-, structuur- en gemeentekenmerken vanzelfsprekend boven individueel niveau.

Als analyseniveau geldt het individuele niveau, warbij de boven-individuele gegevens als context-variabelen worden beschouwd. Voor de probleemstelling van dit onderzoek is het noodzakelijk de verschillen in taakopvatting en functie-uitoefening te beschrijven op het individuele niveau. Verklaringen van deze verschilien kunnen gelegen zijn op beide niveaus. 


\section{Samenvattend:}

Als opzet voor dit onderzoek is gehanteerd een transversale analyse van gegevens, die verkregen zijn uit een steekproef van de populatie van in Nederland werkzame huisartsen. De methoden van gegevensverzameling zijn: zelf in te vullen vragenlijst, observatie door arts-observatoren en selectie uit bestaande CBS-gegevens. Om methodische redenen is de vragenlijst waarmee de taakopvatting wordt gemeten, als schriftelijke enqûete toegezonden aan een groep Nederlandse huisartsen, samengesteld op basis van representativiteit.

\subsection{MEETINSTRUMENTEN}

Voor het onderzoek was het nodig dat twee meetinstrumenten werden ontwikkeld:

a) observatiecategorieën: par. 4.4.1. en

b) taakperceptiemeting: par. 4.4.2.

De ontwikkeling, toepassing, geldigheid en betrouwbaarheid van deze instrumenten zullen achtereenvolgens worden beschreven.

\subsubsection{OBSERVATIE-CATEGORIEEN}

Zoals in het voorgaande reeds werd aangegeven, is gekozen voor observatie als techniek van gegevensverzameling gericht op de functies die hulsartsen uitoefenen. Dit betekent dat de observator de door ons opgestelde categorieën moet verbinden aan door hem waargenomen handelingen. De interpretatie-breedte die hem daarbij wordt gelaten, is een centrale factor in de geldigheid van het instrument. Naarmate de observatiecategorieën meer overeenkomen met de direct waarneembare activiteiten, is de betrouwbaarheid groter. Echter, alleen de registratie van zichtbare handelingen is voor ons betrekkelijk oninteressant. De huisarts verricht een groot aantal min of meer gelijke handelingen met verschillende intenties. De combinatie: "intentie + handeling" is daarom van belang voor de rubricering van activiteiten. 
Bij het ontwerpen van de vereiste observatiecategorieën werden we gesteld voor de hieronder schematisch weergegeven situatie.

Figuur 5: Overzicht van probleemgebieden bij de ontwikkeling van observatiecategorieën

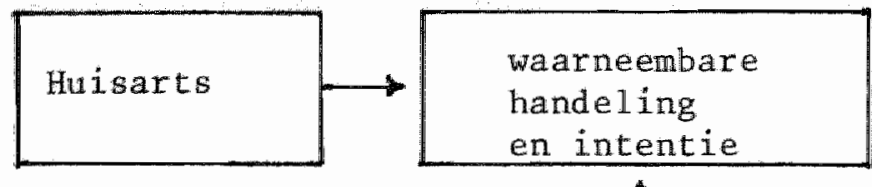

(a)

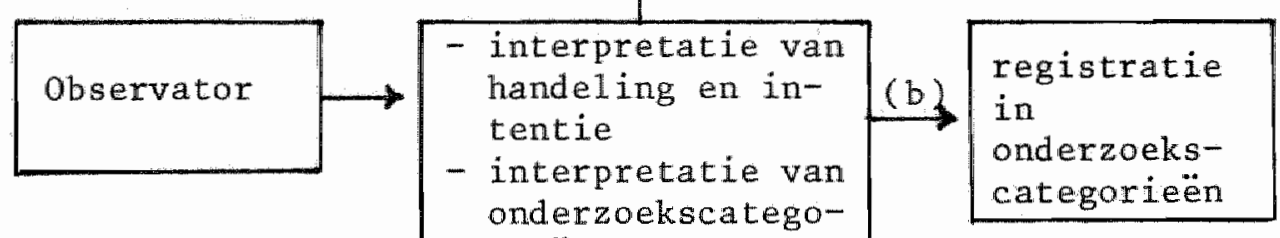
rieën

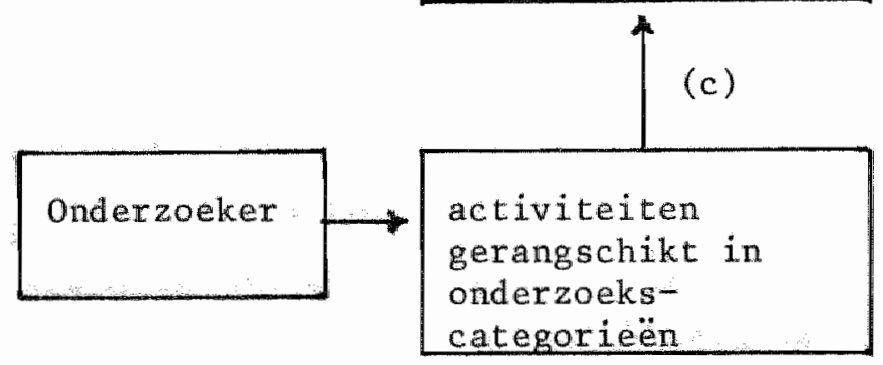

Als observatoren werden arts-assistenten gevraagd, in hun opleidingsjaar voor huisarts. De onderzoekscategorleën waren geformuleerd en getest door twee artsen, warvan eén met ruime praktijkervaringen als huisarts.

op basis van de uit deze test verkregen gegevens bleek het mogelijk de activiteiten geformuleerd in 3.1 . In relatie tot 
de functies, te hanteren als observatiecategorieën (probleem c). Door gebruik te maken van (huis-)artsen als observator werd het probleem van interpretatie van waargenomen handelingen naar intentie van de uitvoerende huisarts (probleem a) binnen één kader gesteld.

In 1977 is een proefmeting verricht bij 7 huisartsen in Zuid-Limburg en 10 huisartsen in de regio Arnhem. Deze meting was opgezet om de toepassing van observatie in de huisartspraktijk als methode van gegevensverzameling te onderzoeken. Naast de praktische uitvoerbaarheid werden de problemen van geldigheid en betrouwbaarheid, in figuur 5 aangegeven door de punten $a, b$, en $c$, bestudeerd.

ook het instrueren in het gebruiken van observatiecategorieën was goed uitvoerbaar. Doordat huisarts en observator eenzelfde opleiding bezitten, bleek het interpreteren van de waargenomen handelingen zonder veel moeilijkheden mogelijk te zijn. De categorie-aanduidingen bleken met slechts beperkte omschrijvingen voor huisartsen-observatoren te verwijzen naar duidelijk afgegrensde gebieden van handelingen.

Bij de uitvoering van de observatie in het eigenlijke onderzoek deden zich drie problemen voor: het vinden van arts-observatoren, het krijgen van medewerking van de huisartsen en de registratie en verwerking van de gegevens.

De benodigde observatoren zijn via contacten met de Lande11 jke Vereniging van Arts-assistenten verkregen en op contractbasis voor de tijd van 3 maanden aan de Rijksuniversiteit Limburg verbonden.

De huisartsen die hun praktijk en hun werk wilden laten observeren, zijn geworven dankzij de bemiddeling van contactpersonen in de Plaatselijke Huisartsenverenlgingen.

Het registreren van de gegevens gebeurde in de pilotstudie met behulp van voorgedrukte formulieren, warop de observator het begin en eindpunt van een categorie moest aangeven op een tijdbasis van minuten. Bovendien werden in deze pilotstudie verschillende formulieren voor vrij spreekuur, afspraak-spreekuur, visite, overige en verwijzingen gebrulkt. Zowel de keuze tussen het gebruik van de verschillende formulieren als het volgen van de tijd, leverde de observator nogal veel moeilijkheden op. Bovendien was de computerver 
werking - en net name de codering - nogal omslachtig, waardoox de nodige verwerkingsfouten ontstonden.

In het ulteindelijke onderzoek is daarom een andere methode gehanteerd. Speciaal ten behoeve van dit onderzoek is een zogenaamde gedragsobservatie-registrator (G.0.R.) ontwikkeld, in samenwerking met de technisch-instrumentele werkplaats van de Rijksuniversitelt Limburg, (Boots, 1980). Met behulp van dit apparaat werd het mogelijk dat de observator alleen het begin van een categorie aangaf, waarbij automatisch de scorling op een tijdas met intervalien van 10 seconden werd vastgelegd, onder gelijktljdige registratie van een vooraf ingestelde rubriek: visite, afspraak-spreekuur, vrij spreekuur en overige. Het opslaan van deze scoringen vond plats in een geheugen-cassette. De inhoud hiervan werd vervolgens - met behulp van een hiervoor ontworpen interface direct op MINC-apparatuur overgenomen. Aldus werden de door de observator gedane warnemingen volgens een vooraf opgesteld code-identificatie-systeem met de bijbehorende rubricering en tijdsduur vastgelegd op magneetschijven. Deze ruwe gegevens werden door ons gecontroleerd op fouten, die ontstaan waren door haperende apparatuur, onoplettendheid van observatoren, e.d. De controle beruste niet alleen op het opsporen van interne logische inconsistenties in de gegevens, maar ook op het corresponderen van de oberservatiegegevens met de, gedurende de observatie schriftelijk vastgelegde, Informatie in het zogenaamde logboek, dat iedere observator bijhleld. Hierin werden al die gebeurtenissen vermeld die van een afwijkende vorm waren, en niet in de observatiecategorieën konden worden weergegeven. Hieronder vielen bijvoorbeeld het langdurig verrichten van énzelfde handeling, zoals het doen van consultatiebureauwerk; evenals het gelijkt1jdig behandelen van verschillende patiênten. Bovendien werd het speclalisme waarnaar verwezen werd in het $10 \mathrm{~g}-$ boek vastgelegd. Wanneer interne inconsistenties of nietcorresponderende gegevens tussem observatie en logboek werden geconstateerd, probeerden we deze met behulp van de observator te corrigeren. Bij twijfel werd de betreffende registratie ult het bestand verwijderd. Alle registraties waarbij mogelijke mechanische fouten konden zijn ingeslopen werden zonder meer verwijderd. De apparatur, en met name de geheugencassettes, werden zeer frequent gecontroleerd, gemiddeld $1 x$ per week. 
De uitval ten gevolge van mechanische defecten bedroeg minder dan $1 \%$ van het totale bestand.

Omdat de observaties plaatsvonden gedurende maximal 20 uur in éên praktijk in êên week, en wel tussen 8.00 en 18.00 uur, werden voor de resterende tijd tussen de observaties speciale registratiekaarten gehanteerd, die door de huisarts zelf werden ingevuld. Hierop werd gevraagd naar een globale aanduiding van de activiteiten gedurende avond- en nachtdienst en, indien van toepassing, weekend- en waarnemingsdiensten.

In totaal werden dus ten behoeve van de functiemeting de volgende gegevens per huisarts verzameld:

1. 20 uur geobserveerde activiteiten in vór rgecadeerde categorieën en rubrieken, op een tijdas met een interval van 10 seconden;

2. een logboek door de observator ingevuld, waarin gegevens over alle bijzondere omstandigheden die zich tijdens de observatie voordeden, en ook in ieder geval het speciaIisme waarnaar verwezen werd, per afzonderlijk geregistreerde verwijzing;

3. door de geobserveerde huisarts zelf in te vullen gegevens over de avond- en nacht-waarneming - en/of weekenddiensten.

Wat betreft de geldigheid van de functiemeting wordt hier slechts volstaan met de vermelding dat iedere indeling in omschreven categorieën berust op de "face value" van deze aanduiding, naar het oordeel van ervaren hulsartsen. In de rapportage, die nog door mijn collega-onderzoeker zal worden gepubliceerd, wordt hierop nader ingegaan.

De betrouwbaarheid betreft de hierboven onder 1 . genoemde gegevens. Ter verkrijging van een zo groot mogelijke betrouwbaarheid werden de volgende matregelen getroffen.

Aan het begin van de observatieperiode werd per categorie een instructie verstrekt aan alle observatoren. Deze instructie werd mondeling in een gezamenlijke bijeenkomst met de huisarts-onderzoeker doorgenomen op onduidelijkheden of de mogelijkheid van meerdere interpretaties. Bovendien werd gedurende deze eerste bijeenkomst geoefend met observeren en de G.0.R.-apparatuur aan de hand van hiervoor speciaal geselecteerde video-opnamen van hutsartsenspreekuren. 
Deze videobanden betroffen "nomale" consulten, dus geen speciaal voor instructies of demonstraties vervaardigd materiaal. Alle activiteiten die op deze banden waarneembaar waren, werden vór de instructiebijeenkomst door de huisarts-onderzoeker geobserveerd en geregistreerd in "onze" categorieên, op grond van de geldende instructies. Aansluitend aan de observatie van de opname door de observatoren gezamenlijk en gelijktijdig zonder onderling overleg - werden de door de observatoren gemaakte scores vergeleken met de resultaten van de onderzoeker. Indien noodzakelijk, werden de instructies op grond van deze vergelijking bijgesteld.

Gedurende de observatieperiode werden nog vier bijeenkomsten met de observatoren gehouden. Bij deze gelegenheden werden nleuwe videobanden aangeboden en gehanteerd, zoals hierboven omschreven. Bovendien werden per observator de interpretatieproblemen besproken, telkens resulterend in éénduidige (nieuwe) afspraken. Geconstateerde duidelijke afwijkingen, werden door ons gecorrigeerd en in het reeds verzamelde materiaal verwerkt. Deze bijeenkomsten vonden plaats na de eerste, tweede, derde en zesde week van de observatieperiode. Aan de observatiegegevens van de op videoband aangeboden huisartsenwerkzaamheden, zijn de scores van de arts-onderzoeker toegevoegd. Per vórkomende observatiecategorie zijn de verschillen tussen de observatoren in scores - op vó́rkomen ến tijdsduur $-{ }_{2}$ op significante afwijkingen getoetst met behulp van de $\chi^{2}$ toets. Uit deze toetsing blijkt dat de observatoren onderling, en in vergelijk met de "te verwachten score", vrijwel geen significant verschillende waarmemingen deden, (bijlage 2).

\subsubsection{TAAKPERCEPTIE-METING}

De taakperceptle werd gesplitst naar de zes functies (zie hoofdstuk 3), warbij per functie uitspraken werden voorgelegd, die voornamelijk het zogenaamde facultatieve gebied betroffen uft het 'Takenpakket', (L.H.V., 1977). Per functie betekende dit de hiernaast genoemde onderwerpen, waarbij telkens twee (positieve en negatieve) uitspraken werden geformuleerd betreffende hetgeen de huisarts tot zijn taak behoorde te rekenen. 
Diagnostiek:

Therapie:

Begeleiding:

Preventie:

Verwijzing binnen de gezondheidszorg

Verwijzing buiten de gezondheldszorg
- sociale problemen in de diagnose betrekken of zich beperken tot somatiek;

- als huisarts zoveel mogelijk zelf diagnosticeren en dan pas gericht verwilyzen;

- gesprekstechniek als eigen vaardigheid uitoefenen;

- bevallingen zelf begeleiden;

- zo weinig mogelijk verwijzen naar hogere echelons;

- begeleiding door de huisarts ook van high risk-groepen, psychiatrische patiënten, stervenden en revalidatiepatiënten;

- niet alleen individuee1, ook groepspreventie als huisartsentaak;

- niet alleen beperken tot somatische aandoeningen, ook uitbreiden tot maatschappelijke probleemsituaties betreffende sociale klachten;

- relatie met specialisten met betrekking tot te delegeren verantwoordelijkheden;

- kostenaspecten mee laten wegen in het a1 of niet verwijzen;

- verantwoordelijkheid van de huisarts voor hulpverlening bif sociale problemen;

- verwijzende functie van de huisarts bij matschappelijke problemen.

Aan deze vragen werden telkens per functie twee vragen toegevoegd met betrekking tot de ervaren tijdsdruk en de onderwonden steun bij de betreffende functie-uitoefening door aanwezige gezondheidszorgvoorzieningen. Tenslotte werden acht vragen gesteld betreffende ến van de centrale elementen in "condities", namelijk het samenwerken met andere eerstelijnswerkers. Zoals in hoofdstuk 3 reeds werd aangegeven, wordt de meting van aanwezigheid van gezondheidszorgstructuren niet alleen op objectleve informatie gebaseerd. In de vragenlijst is opgenomen een aantal voorzieningen, waarvan aan de huisartsen gevraagd is om an te geven hoe 
frequent men deze gebrulkt en hoe groot het nut is dat men hieraan toekent bij de uitoefening van de functie als huisarts.

Het niveau, warop diagnostiek en therapie zouden moeten worden uitgevoerd, is gemeten aan de hand van een aantal uitspraken, die de uitgebreldheid van het somatisch-technisch handelen van de huisarts proberen te traceren.

De vragenlijst werd in zijn conceptvorm doorgesproken met de leden van de L.H.V.-Werkgroep Takenpakket. Vervolgens werd de eerste versie voorgelegd aan twee huisartsen, die namens het Medisch Regionaal Centrum Zuid-Limburg ons project begeleidden en aan een aantal artsen en niet-artsen uit de eigen universitaire kring. De uitspraken werden, op grond van uit een proefmeting verkregen resultaten, vervolgens geselecteerd op onderscheidend vermogen, begrijpelijkheld en eenduldigheid. Uiteraard werd op basis van de gegeven commentaren ook de lengte, opbouw en lay-out van de lijst bijgesteld.

De vragenlifst werd aan de geobserveerde huisarts door de observator overhandigd. De huisarts werd geacht zelfstandig de lijst in te vullen, waarna de observator voor retournering zorgdroeg. Aan de huisartsen in de landelijke, representatieve steekproef werd de vragenlijst, in dezelfde periode als de observaties werden uitgevoerd, per post toegezonden.

De geldigheid van de vragenlijst is gebaseerd op de "face value" en "expert opinion". De geconstrueerde geldigheid betreft de vooraf gecreëerde samenhang van de ultspraken en de wijze van selectie.

De betrouwbarheld van de meetresultaten hebben we bovendien nog op de volgende wijze trachten te verhogen. Naast de steekproef die we getrokken hebben ten behoeve van het feltelijk hoofdonderzoek volgens de eerder beschreven probleemsteling, hebben we bovendien een grotere steekproef samengesteld uit het huisartsenbestand in Nederland. Deze werd getrokken op basis van representativitelt op de kenmerken: solist/niet-solist; urbanisatiegraad van praktijkgemeente en praktijkgrootte (zie 4.5.). Aan deze steekproef werd tevens dezelfde vragenlijst voorgelegd met een begeleidende brief 
van de L.H.V.-voorzitter. Het gebrulk dat we van deze resultaten uit de "post-enquête" maken is tweeërlell: allereerst een contrôle op de representativiteit van de eigen steekproef, anderzijds een mogelijkheid om de meting van taakopvattingen op betrouwbaarheid te onderzoeken.

Samenvattend:

Ten behoeve van het onderzoek zijn twee nieuwe instrunenten ontwikkeld, getest en toegepast, namelijk de observatiecategorieën en de taakperceptievragenlijst. In een proefonderzoek werden betrouwbaarheid en geldigheld van het observatie-instrument onderzocht. In het uiteindelijke onderzoek werden naast de observatiegegevens, aanvullende gegevens genoteerd waarmee betrouwbaarheidcontrole mogelijk was. Tijdens de observatieperiode werden tevens een vijftal test-observaties uitgevoerd met behulp van video-opnamen. Het verschil tussen observatoren en onderzoekers bij de toepassing van de observatiecategorieën bleek over vrijwel alle categorleën niet significant.

De meting van de taakopvatting door middel van een vragenlijst werd niet alleen in de onderzoeksgroep uitgevoerd, maar tevens in een representatieve steekproef van Nederlandse huisartsen. Bij de constructie van de uiteindelijke schalen volgens onderdelen van de taakopvatting, werden de uitkomsten uit de representatieve steekproef gebruikt. De geldigheid van beide instrumenten berust op "face value" van terzake kundige huisartsen en onderzoekers.

\subsection{STEEKPROEVEN}

Zoals in het voorgaande reeds aangegeven is, zijn ten behoeve van dit onderzoek twee steekproeven getrokken: éen groep huisartsen warbij alle onderdelen van het onderzoek werden uitgevoerd (verder te noemen: kleine steekproef), en een groep huisartsen waraan alleen de perceptievragenlijst werd voorgelegd (:grote steekproef). 


\subsection{1. "KLEINE" STEEKPROEF}

De gekozen techniek van gegevensverzameling thet betrekking tot functie-uitoefening, namelijk de directe observatie, stelt praktische beperkingen aan de omvang van de steekproef. Op grond van de ons ter beschikking staande middelen en om een nog hanteerbare organisatie te behouden in relatie tot het beschlkbare researchmanagement, werd gekozen voor een kleine steekproef van 93 huisartsen. Bij de samenstelling van deze steekproef golden de volgende overwegingen:

1. In de te onderzoeken groep huisartsen moeten zo goed mogelijk alle voor de probleemstelling relevante kenmerken, zowel van hulsartsen, praktijken, als van de structurele omgeving, aanwezig zijn;

2. de bereldheid tot medewerking van huisartsen vergt een zorgvuldige voorlichtings- en voorbereldingsprocedure, wardoor de kans op selectieve uitval - niet denkbeeldig bij een "gevoelig" onderwerp en uitgevoerd met behulp van een "bedrelgende" methode - zo gexing mogelijk wordt gemaakt.

Uit de eerste overweging volgde de samenstelling van een "purposive quota sample", (Kerlinger, 1974, pag. 129), gericht op de volgende kenmerken:

- Landelijke diversiteit van regionale kenmerken met betrekking tot urbanisatie en voorzieningenniveau;

- spreiding in praktijkkenmerken, met name samenwerkingsvorm, wel of niet apotheekhoudend, omvang en verhouding van aantal ziekenfondspatiënten ten opzichte van particuliere patiënten;

- spreiding in persoonskenmerken, vooral wat betreft leeftijd en/of ervaring als huisarts.

Voor het bereiken van de regionale spreiding werd Nederland verdeeld in 24 mini-provincles, volgens een ontwerp van het Ministerie van Binnenlandse Zaken d.d. februari 1977.

Voor deze indeling werd gekozen, omdat indertijd het voornemen bestond de regionalisatie, ook ten behoeve van de gezondheldszorg, te laten verlopen in deze geografische indeling. 
In samenwerking met het MEMIC (Medisch en Matschappelijk Informatiecentrum) van de Rijksuniversiteit Limburg werden deze 24 miniprovincies vergeleken op : urbanisatiegraad, huisartsendichtheid en anwezigheid van gezondheldszorgvoorzieningen. Uit de hierop gebaseerde typologieën werden de volgende acht miniprovincies geselecteerd:

1. Overijssel en Groningen: "platteland met stadskern";

2. Zuid-Limburg en Kempenland: "sterk ge-urbaniseerd platteland);

3. Gooi, Eemland en Hameland: "forensisch gebied";

4. Haagland en Rijnmond: "grote steden".

$B i j$ het realiseren van diversiteit in praktijk- en persoonskenmerken speelde tevens de hierbovengenoemde tweede overweging een rol. De selectie van de uiteindelijk in de steekproef op te nemen praktijken verliep via de L.H.V.-districtvertegenwoordigers in de genoemde gebieden. Aan deze districtvertegenwoordigers werd de opzet en doelstelling van het onderzoek in een persoonlijk contact met de onderzoekers uitgelegd. Aan hen werd gevraagd om in "hun" district 12 artsen te zoeken, met de voor ons onderzoek relevante persoonskenmerken en praktijksituaties. Met de aldus samengestelde groepen werd per regio een voorlichtend gesprek gehouden door de onderzoekers. Uitval door geweigerde medewerking heeft zich niet voorgedaan.

\subsection{2. "GROTE STEEKPROEF"}

Een "random"-steekproef van 900 huisartsen werd getrokken uit het totaal van in Nederland zelfstandig gevestigde en ful1-tine werkzame huisartsen per 1-1-1979. Hiervoor werd gebruik gemakt van het adressenbestand van het Nederlands Huisartsen Instituut. De vragenlijst werd vergezeld van een aanbevelingsbrief van de L.H.V. toegezonden. De respons van $70 \%$ mag voor een schriftelijke enquete hoog genoemd worden. $\mathrm{Na}$ controle bleek een aantal van 614 vragenlijsten geschikt voor verdere verwerking. 


\subsubsection{REPRESENTATIVITEIT}

Vergelijking van beide steekproefen op voor dit onderzoelk relevante variabelen, met de populatiegegevens levert het volgende resultaat op.

Tabel 1: Vergelijking naar urbanisatiegraad van beide steekproeven met de populatie van zelfstandig gevestigde huisartsen in Nederland die full-time werkzaam $21 j n$, per 1-1-1979, in percentages van het totaal

\section{Populatie}

Grote

Steekproef

Kleine

Steekproef

1. Platteland

12,1

13,2

11,8

2. Verstedelijkt platteland

21,7

22,5

20,4

3. Forensengemeenten

13,8

14,6

17,3

4. Kleine steden

(<50.000 inw.) 16,4

15,2

16,1

5. Grote steden

(> 50.000 1nw.) 22,7

22,0

24,7

6. Den Haag, Amsterdam,

Rotterdam 13,3

12,5

9,7

$$
100,0 \%
$$

$\mathrm{N}=$

5041
$100,0 \%$

614
$100,0 \%$

93

Het verschil tussen de populatie en de beide steekproeven is niet significant, $\left(x^{2}=.02 ; x^{2}=.03 ; \alpha=.05\right)$. 
Tabel 2: Vergelijking naar praktijkvorm van belde steekproeven met de populatie van zelfstandig gevestigde huisartsen in Nederland die full-time werkzaam $z i j n$, per 1-1-1979 in percentages van het totaal

Populatie

Grote

Kleine

Steekproef

1. Solist

64,3

67,5

65,1

2. Niet-solist

35,7

32,5

34,9

3. Apotheekhoudend 26,5

28,8

32,3

4. Niet-apotheekhoudend

71,2

67,7

$X^{2}=$ resp. 2,$74 ; 0,02 ; 1,67 ; 1,61 ; \alpha=.05$

Uit de vergelijking van beide steekproeven met de populatie blijkt voor de betreffende kenmerken geen significant versch11 te bestaan. Ook de combinatie van deze kenmerken levert geen significante afwijkingen van de populatiegegevens op.

Samenvattend:

Het observatieonderzoek ten behoeve van de functie-analyse is uitgevoerd in een steekproef van 93 hulsartsen. Deze steekproef werd samengesteld aan de hand van een aantal kenmerken van de personen, praktijken en hun omgeving, dat relevant is voor de probleemstelling. De medewerking van de geselecteerde huisartsen werd verkregen door bemiddeling van regionale contactpersonen.

Een aanvullende steekproef, waarbij alleen de vragenlijst werd voorgelegd, is getrokken uit het totale huisartsenbestand, per 1-1-1979, op basis van representativiteit. Beide steekproeven zijn op significante verschillen met de populatie onderzocht; deze bleken niet aanwezig te zijn. 
HOOFDSTUK 5

BESCHRIJVING VAN ONDERZOEKSRESULTATEN

\subsection{TIJDBESTEDING NAAR FUNCTIES}

Zoals in hoofdstuk 4 werd aangegeven, is het aantal geregistreerde activiteiten gerubriceerd naar functies. Naast de functies, die op grond van de plaats die de huisarts in het gezondheldszorgsysteem inneemt kunnen worden onderscheiden, zijn de resterende activiteiten eveneens in hoofdrubrieken samengevat. Ondat de observatoren in overleg met de geobserveerde huisarts de spreiding van de 20 uur (bestemd voor observatie) konden kiezen op zelf te bepalen dagdelen, is allereerst gecontroleerd of er geen overwaardering van tijdbesteding op bepalde dagen voorkomt. Zoals uit onderzoek van Aulbers en De Waard (1970) blijkt is de spreiding van contacten over weekdagen ongeveer gelijk van maandag tot en met vrijdag, en over de uren per dag ligt meer dan $90 \%$ tussen 8.00 uur -17.00 uur. Wanneer we de totale geobserveerde t1jd op $100 \%$ stellen verkrijgen we het in tabel 3 weergegeven beeld van de verdeling van tijdbesteding naar functies en rubrieken. Een verrekening van feitelijke uren is moge$11 \mathrm{jk}$ met behulp van de resultaten uit het rapport van Paardekoper en Hofman, (1976). Hierin wordt een gemiddeld aantal werkuren vermeld wan 51,1 per week, variërend van 53,1 voor sollstisch werkende en apotheekhoudende huisartsen tot 47,8 voor samenwerkende, niet-apotheekhoudende huisartsen. (VoIledige categorieën met tijdbesteding in bijlage 3).

Enkele opmerkingen naar aanleiding van tabe1 3:

- De variatie in de tijdbesteding verschilt sterk per groep activitelten. Voor de tijdbesteding aan de functies "diagnostlek, theraple, begeleiding en preventie", evenals voor de rubrieken "condities, reistijd en telefoon", blijkt een redelijke spreliding in de meetresultaten. De tijdbesteding aan "binnen de gezondheidszorg" en aan "privé" vertoont 
Tabel 3: Tijdbesteding per functie en aanvullende rubrieken, in procenten van totale werktijd per dag ( 8.00 uur -18.00 uur)

Gemiddelde Standaardtijd per arts deviatie
Relatieve standaarddeviatile
Diagnostiek
Therapie
Begeleiding
Preventie
Verwijzing binnen

gezondheidszorg

Verwijzing buiten

gezondheidszorg

Condities

Activiteiten als arts

Apotheekwerk

Socilal contact

Telefoon

Reistijd

Prive
22,1

15,1

6,0

5,2

2,7

0,3

14,2

3,4

0,4

3,0

5,8

11,4

10,6
6,1

0,28

5,3

0,35

3,6

0,60

3,5

0,67

2,1

0,78

0,6

2,00

6,7

0,47

4,9

1,44

1,4

3,50

2,8

0,93

3,8

0,66

4,9

0,43

7,6

0,72 
een veel grotere spreiding, terwijl de overige activitelten - gelet op de relatieve standaardafwijking - niet voor varlantie-analyse in aanmerking komen.

- Het is niet verwonderlijk dat bijna een kwart van de tijd per dag door de huisartsen wordt besteed aan diagnostiek. Hoewel actueel cijfermatig vergelijkingsmateriaal voor de Nederlandse situatie ontbreekt, komt die uitkomst overeen met de teneur van velerlei beschouwingen, zowel beleidsmatig als meer op onderzoek gericht, dat de huisarts een centrale intakepositie in de gezondheidszorg vervult, (Ridderikhof, 1981; Peters, 1982; Lamberts, 1982).

- De tijd die besteed wordt aan diagnostiek en therapie tezamen, de curatieve zorg, bedraagt $37,2 \%$. Door BloklandKüler (1.974) wordt voor vergelijkbare activiteiten $39 \%$ gevonden, terwij1. Bremer en Van Westrenen (1964), eveneens het zeer grote aandeel van curatieve zorg in de huisartspatiënt-contacten vermelden.

- Tets meer dan de helft van een werkdag wordt besteed aan de in dit onderzoek geformuleerde systeemfuncties gezamen$1 i j k$. Wanneer we afzien van de niet nader te benoemen rubrlek "telefoon", dan blijkt aan "condities" ruim éénderde van de resterende tijd te worden besteed. De vaak gehoorde verzuchting dat "administratie en vergaderen" zoveel tijd kost, lijkt door dit cijfer te worden ondersteund.

- Het percentage "privê" moet worden bezien in het licht van de instructie aan de observatoren. Op grond hiervan zullen langdurige aaneengesloten periodes "privé" niet voorkomen. Wanneer bijwoorbeeld een middag vrijaf wordt genomen door een huisarts dan is die periode niet geobserveerd! Wel de over een dag versprelde lunch- en koffiepauzes, persoonlijke verzorging e.d.

- Bezlen op een 24-uurstijdbesteding geeft de hier weergegeven verdeling in princlpe een "vertekening" in de richting van de direct patiënt-gebonden werkzaamheden. Het niet-patiënt-gebonden werk kan gedurende avond- en weekendtijd worden voortgezet. De mate waarin dit gebeurt is op basis van onze gegevens niet te schatten. 
- Opmerkelijk tenslotte is de zeer geringe hoeveelheid tijd die besteed wordt aan "verwijzing buiten de gezondheidszorg". Tot de categorie hulpverleners buiten de gezondheidszorg werden gerekend: het algemeen matschappelijk werk, bejaarden-hulp, gemeentelijke sociale dienst en dergelijke. De betekenis van de huisartsentaak voor andere dan gezondheidszorgvoorzieningen is, in tijdbesteding uitgedrukt, zeer gering.

\subsection{VERWIJZINGEN}

Het verwijzen door huisartsen is niet alleen vastgelegd als relatieve tijdbesteding, maar ook in proportionele verhouding ten opzichte van het totaal aantal geobserveerde consulten. Het aantal verwijzingen naar personen en/of instanties buiten de gezondheidszorg is dermate gering dat verdere bewerking niet zinvol leek.

Tabel 4: Aantal verwijzingen binnen de gezondheidszorg per 100 geobserveerde consulten

Verwijzingen per 100 consulten $\mathbb{L}$ klassen
Aantal huisartsen

(: 93)

$\begin{array}{rrr}0 & -1 & 1 \\ 2 & -5 & 15 \\ 5 & -10 & 34 \\ 10-15 & 32 \\ 15-20 & 8 \\ 20 & & 3\end{array}$

Gemiddeld: 9,9 verwijzingen per 100 consulten. Standaard-deviatie: 4,8 ; relatieve standaarddeviatie: 0,48 . 
Dit cijfer lat zich niet vergelijken met verwijscijfers, zoals die meestal berekend worden op het totaal aantal (ziekenfonds-) patienten. Eenzelfde berekeningswijze is wel aanwezlg bij Posthuma en Van der Zee (1978), die materiaal bewerkt hebben dat afkomstig was van Van Es en Pij1man. De door hen gevonden cljfers, resp. 9,56 en 3,35 vertonen sterke overeenkomsten met onze resultaten. Door dezelfde auteurs wordt duidelijk gesteld dat de variabele: "verwijzen per 100 consulten" en "aantal verwijzingen per 1000 ziekenfondspatiënten" niet zonder meer uit elkaar af te leiden zijn.

Bij het verklaren van verwijsgegevens wordt vaak onderscheid gemaakt naar de initiatiefnemer (Posthuma en Van der Zee, 1978; Van der Zee, 1982). Het vaststellen van verschillen in type verwijzing op grond van de mate waarin de huisarts of de patiënt de initiatiefnemer voor de verwijzing is, blijft een discutabele zaak.

Zoals uit de discussie tussen Pel (1975) en Melker (1975) blijkt, bestaat er verschil van mening over de mate warin de huisarts invloed kan uitoefenen op het aantal verwijzingen waarvoor noch hijzelf, noch de patiënt, directe initiatiefnemer is (de zogenaamde "pseudo-verwijzingen"),

(De Vries, 1975). In ons onderzoek is het onderscheid naar initiatiefnemer bij de totstandkoming van een verwijzing niet gemaakt. Het doel van ons onderzoek is gelegen in de beschrijving en mogelijke verklaring van de feitelijk geobserveerde tijd- en werkverdeling, ongeacht de redenen die tot de arts-patiëntcontacten hebben geleid. Bovendien vormen de verwijzingen die geheel administratief worden afgehandeld, zoals "herhaal-verwijskaarten", geen onderdeel van de verwijsproportie die wij registreerden.

Wel is onderscheid gemaakt naar het doel van de verwijzing, gezien vanutt de functlevervulling door de huisarts.

Vastgesteld is of de verwijzing gericht was op diagnostische, dan wel therapeutische activiteiten van specialisten in het tweede echelon. Dit verschil berust op de al dan niet uitgesproken doelstellingen van de huisarts, welke de observator kan vaststellen. De gemiddelde proportie per 100 consulten bedraagt voor de diagnostische verwijzingen: 4,2 (stand dev. 1,5); voor de therapeutische verwijzingen: 5,5 (stand dev. 1,8 ). 


\section{Samenvattend:}

De functies die huisartsen vervullen in de Nederlandse gezondheidszorg zijn gemeten aan de hand van de geobserveerde activiteiten in hun dagelijks werk. De werkzaamheden die niet tot de door ons geformuleerde functies konden worden gerekend, zijn in aanvullende categorieën ondergebracht. Een overzicht van de omvang en onderlinge verhouding van de functies en voornaamste categorieën geeft figuur 6 .

Figuur 6: Overzicht van tijdbesteding door de huisarts

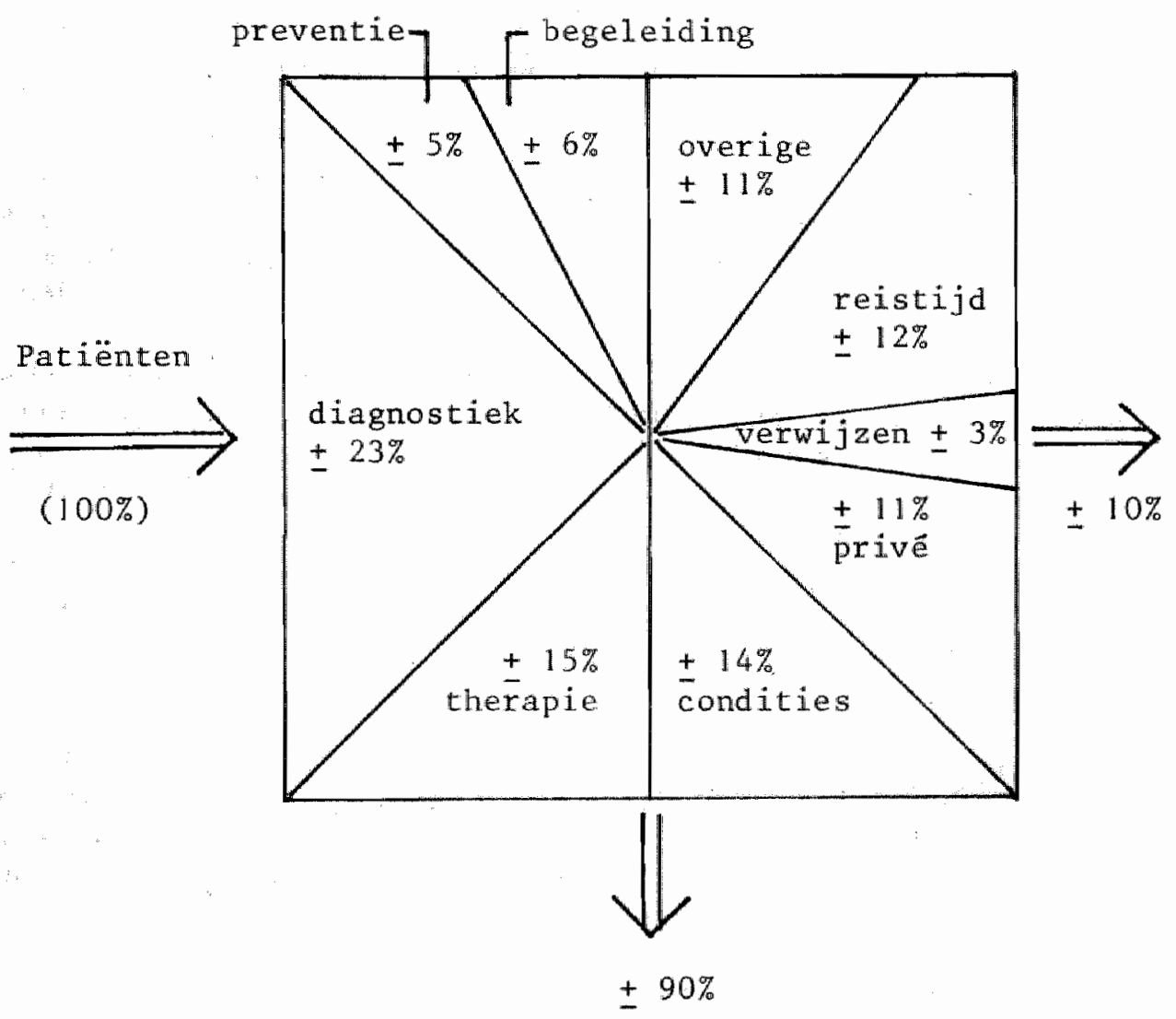


5.3. OPVATTINGEN TEN AANZIEN VAN DE HUISARTSENTAKEN

\subsubsection{ALGEMEEN}

Bif de meting van opvattingen, die huisartsen hebben ten aanzien vau de inhoud, het niveau en de uitoefening van hun taken, zijn we uitgegaan van de discussies rondom de verschillende takenpakketten zoals die opgesteld zijn door L.H.V. en K.N.M.G.-commissies ( $z$ ie hoofdstuk 2.2. en 4.2.). De vragenlijst die voor deze meting gebruikt is, werd ook voorgelegd aan de representatieve steekproef van Nederlandse huisartsen. Op grond van de hieruit verkregen gegevens, hebben we geprobeerd enige structurering in het totale pakket vragen aan te brengen. Deze structurering willen we ook hanteren bij de verwerking van de gegevens die bij de steekproef van geobserveerde huisartsen zijn verkregen.

De meningen van huisartsen omtrent de taakbreedte, tijdsdruk en voorzieningenniveau (de vragen 12.1 . tot en met 18.6 . uit de vragenlijst, zie bijlage 1) werden onderzocht op hun onderlinge samenhang. Hiertoe werd een associatie-matrix geconstrueerd met behulp van de maximale kapa (Cohen, 1968; Hildebrand, 1977).

Door de wijze waarop deze mat wordt berekend kunnen ook scheve verdelingen en niet-lineaire samenhangen in de analyse worden betrokken. Op de aldus verkregen associatie-matrix werd cluster-analyse uitgevoerd met behulp van het cluster-programma van Wishart, (1978). Volgens de methode van clustering, te benoemen als hiërarchisch, complete linkage (Everitt, 1974) werd hlermee het in tabel 5 weergegeven resultat verkregen.

Enkele opmerkingen naar aanlelding van tabel 5:

- De samenhang die gevonden is tussen de antwoorden op de onderscheiden vragen is niet erg sterk te noemen (Boots, 1981). Gezien het feit dat de gebruikte vragen betrekking hebben op binnen de beroepsgroep discutabele onderwerpen zijn twee conclusies mogelijk:

ofwel de onderwerpen zijn alleen discutabel voor de kleine groep huisartsen in commissies en bestuur van de beroepsverenigingen en niet voor de achterban;

ofwel de discussie omtrent de verschillende onderwerpen is 
Tabel 5: Cluster-indeling van opinievragen met betrekking tot de taakbreedte in de "grote" steekproef $(N=614)$

Clusterbenoeming

Opinievragen

(nummer uit vragen-

lijst uit bijlage 1 )
Clusterniveau

1. zelf sociale pro-

12.4 12.6. 15.7 .135 blemen aanpakken als huisarts

17.1. $17.2 . \quad 17.5$.

2. samenwerken met anderen

18.1. $18.3 . \quad 18.4$. .162 18.6. 18.7 .

3. zo weinig mogelijk doorverwijzen

12.5 13.1. 13.5 . .157 14.5. 16.3. 16.4. $16.5 \quad 17.3 \quad 17.4$

4. zoveel mogelijk 14.2 zelf begeleiden 14.6. 15.1. 15.2. en preventief werken

15.5. $\quad 15.6$.

5. werken onder

12.8. $\quad 13.9 . \quad 14.8$. .261 grote tijdsdruk

15.9 . 16.7 . 17.7 .

6. voorzieningenniveau 14.7 . 15.3. 15.8 . .206 is voldoende voor 17.6 . begeleiding en preventie. 
van dien aard, dat een mening op één punt geen of nauwelijks voorspellende betekenis heeft voor het ingenomen standpunt over een ander onderwerp.

- Het benoemen van de clusters is een arbitraire zaak. De nadere analyse die werd uitgevoerd op de tot clusters gegroepeerde variabelen is richtinggevend geweest. Deze vond plaats zowel met behulp van een per cluster opgestelde nulde-orde-correlatiematrix, als door onderlinge paarsgewijze vergelijking van de afzonderlijke vragen. De hieruit resulterende "bepalende" variabele werd voor benoeming vanuft het cluster gekozen. Enige ondersteuning voor de clusters 1, 2 en 4 wordt gevonden bij Raupp in de door hem gevonden factor II; factor III vertoont sterke gelijkenis met de clusters 5 en 6, (Raupp, 1972, pag. 50). De taakopvatting van een huisarts zoals die door Dopheide (1982) is gemeten, betreft uitsluitend "verwijzen", een verdere splitsing van de vragen die in cluster 3 zijn samengevat.

- De gevonden clusters hebben op zichzelf weinig beschrijvende betekenis. We willen ze gebruiken om een empirische aanwijzing te hebben op grond warvan de gestelde vragen kunnen worden gegroepeerd en gebruikt voor een additieve schalconstructie in de gegevens, die verkregen zijn uit de steekproef van geobserveerde artsen.

\subsubsection{TAAKOPVATTINGEN}

De wragen warmee "opvattingen" van de geobserveerde huisartsen ten aanzlen van taakbreedte, tijdsdruk en het voorzleningenniveau werden gemeten, zijn samengevoegd volgens de clusterindeling die verkregen werd uit de enquêtegegevens van de representatieve landelijke steekproef. Na hercodering ten behoeve van de gelijke richting van alle antwoorden werden de scores opgeteld. De aldus ontstane eindscores vormen een ordinale schaal die tot een vijfpuntsindeling is getransformeerd op grond van het aantal samenstellende vragen. De vragen omtrent het gewenste niveau van diagnostiek en therapie $z i j n$, evenals de vragen ontrent gebruik en nut van ondersteunende voorzieningen, samengevoegd tot ordinale vijfpuntsschalen. 
Tabel 6: Frequentieverdeling in percentages van de antwoorden op de vragen naar taakopvatting

\section{Laag, Hoog, negatief positief}

zelf sociale problemen aanpakken bereldheid tot samenwerking zo weinig mogelijk doorverwijzen zo veel mogelijk begeleiding/

preventie geven

tijdsdruk is belemmerend voldoende ondersteuning door voorzieningen gewenst niveau van somatische diagnostiek gewenst niveau van somatische therapie

$\begin{array}{rr}38.7 & 16.1 \\ 21.5 & 37.6 \\ 1.1 & 83.9 \\ 6.5 & 38.7 \\ 44.1 & 19.4 \\ 11.8 & 52.7 \\ 7.5 & 49.5 \\ 1.1 & 79.6\end{array}$

gebruik van diagnostische voorzieningen

gebruik van therapeutische voorzieningen

gebruik van preventie-voorzieningen gebruik van begeleidingsvoorzieningen

$\begin{array}{rr}20.4 & 30.1 \\ 45.7 & 11.8 \\ 46.2 & 11.8 \\ 68.8 & 5.4\end{array}$

nut van diagnostische voorzieningen

nut van therapeutische voorzieningen

$\begin{array}{rr}1.0 & 71.0 \\ 11.3 & 49.5 \\ 10.8 & 47.3 \\ 22.6 & 33.3\end{array}$

nut van preventie-voorzieningen

22.6

33.3

De verdelingen laten zien dat de meningen redelijk gespreid $z 1 j n$.

- Een negatieve tendens valt te constaterer ten aanzien van het zelf aanpakken van sociale problemen en een meer positieve houding ten aanzien van het zo weinig mogelijk doorverwijzen. 
- Meer verrassend is de ontkenning van de tijdsdruk als belemerende factor bij het ultoefenen van de functies als hulsarts. Waarschijnlijk hangt dit samen met de koppeling die in de betreffende vragen wordt gelegd tussen de tijdsdruk en het gewenste niveau van handelen per functie. Het aangeven van tijdsdruk zou betekenen: beneden het na te streven kwaliteitsniveau werken. Populair gezegd: de tijdsdruk komt de kwaliteit van het geleverde werk niet ten laste!

- Het noodzakelijk geachte niveau van diagnostiek en therapie is hoog. Hoewel de vragen hieromtrent voor het merendeel "facultatieve" taken uit het takenpakket van de L.H.V.-commissle bevatten, zegt toch het merendeel van de ondervraagde huisartsen dat deze activiteiten tot het werkgebied van de huisarts behoren.

- Het gebruik dat men zegt te maken van ondersteunende gezondheidszorgvoorzieningen voor het eigen huisartsenwerk, is niet zo veelvuldig. Het algemeen gebruik is laag te noemen, met uitzondering van de diagnostische faciliteiten. In het bijzonder is het benutten van faciliteiten ten behoeve van begeleiding zeer gering.

- Het nut dat men aan de betreffende voorzieningen toekent is daarentegen wel redelijk hoog. Met een lichte uitzondering voor de voorziening ten behoeve van begeleiding beschouwt een ruime meerderheid van de gevraagde huisartsen de genoemde voorzieningen wel als nuttig voor hun elgen functioneren.

Whineer we de beschrijvende gegevens uit tabel 6 globaal samenvatten dan kan gezegd worden:

De huisartsen achten een hoog niveau van somatische diagnostiek en therapie wenselijk, ze zijn gericht op zelf begeleiden, preventlef werken en zo weinig mogelijk doorverwijzen. Ze voelen zich niet erg gehinderd door tijdsdruk, ook niet door ontbrekende voorzieningen, die men wel nuttig acht mar over het algemeen weinig gebrulkt. Over samenwerking met andere eerstelijnswerkers lopen de meningen zeer sterk uiteen, met een zeer licht overwicht naar de positieve kant. 
Uit de hiervoor kort omschreven meetresultaten en de verzamelde gegevens, resulteren de volgende variabelen, die in het vervolg van dit onderzoek worden gebrulkt.

a) De tijd die per huisarts is besteed aan diagnostiek, therapie, preventie, begelelding, condities en prive, uitgedrukt als percentage van de totaal geobserveerde tijd.

b) Het aantal verwijzingen per huisarts naar hulpverleners in de gezondheidszorg, uitgedrukt als proportie van het totaal aantal consulten gedurende de observatieperiode.

c) Het gemiddeld aantal patiënten per uur per huisarts, gedurende de observatieperiode (: gemiddeld patiëntenaanbod).

d) De taakbreedte per huisarts, een vijfpunts ordinale schaal, samengesteld uit de clusters 1,3 en 4 (zie tabel 5, hoofdstuk 5.3.1.), oplopend in schalwarden van "smal" naar "breed" en met de betrouwbaarheidscoëfftcient $\alpha=.54$.

e) De bereidheid tot samenwerking in het eerste echelon, een vijfpunts ordinale schaal, gebaseerd op de vragen in cluster 2 (zie tabel 5, hoofdstuk 5.3.1.), oplopend in schaalwaarden van "weinig bereldheld" tot "grote bereidheid" en met de betrouwbaarheidscoëfficient $\alpha=.48$.

f) De beschikbare tijd en ondersteunende voorzleningen, een vijfpunts ordinale schaal, samengesteld uit de clusters 4 en 5 (zie tabel 5, hoofdstuk 5.3.1.), oplopend in schaalwaarden van "weinig" tot "veel" en met de betrouwbaarheidscoëfficient $\alpha=.57$.

g) Het na te streven niveau van somatisch-technisch handelen voor de functies diagnostiek en therapie, een vijfpunts ordinale schaal, samengesteld uit de vragen van paragraaf $20 \mathrm{~A}$ en $20 \mathrm{~B}$ uit de vragenlijst (zie bijlage 1), in schaalwaarden oplopend van "laag" tot "hoog" en met de betrouwbaarheidscoëfficient $\alpha=.67$.

h) Gebruik van ondersteunende voorzieningen, een vijfpunts ordinare schaal, samengesteld uit de vragen van paragraaf 19A tot en met $19 \mathrm{G}$ uit de vragenlijst (zie bijlage 1 ), in schaalwaarden oplopend van "welnig" tot "veel" en met de betrouwbaarheidscoëfficient $\alpha=.84$.

i) De praktijkomvang per huisarts. 
f) Het aantal ziekenfondspatiënten als proportie van het totaal aantal ingeschreven patiënten per huisarts.

h) Het al dan niet apotheekhoudend zijn per huisarts, als dummyariabele met de waarde $0=$ niet en $1=$ we 1 .

1) Het al dan nlet solistisch werkzaam zijn - kenmerk voor de praktijkvorm - per huisarts als dummyvariabele met de waarde van $0=$ solist en 1 = niet-solist.

m) Het aantal jaren praktijkervaring als huisarts.

n) De urbanisatiegraad van de gemeente waarin de geobserveerde huisarts praktiseert, een 6 puntsindeling volgens de gangbare CBS-codes.

o) De ratio van het antal kinderen jonger dan 14 jaar, ten opzichte van de totale bevolking in de gemeente waarin de huisarts praktiseert.

De variabelen $a, b, c, i, j, m$ en o $z i j n$ weergegeven op een intervalschaal met 10 klassen van gelijke grootte, verkregen uit de range van gemeten waarden.

De onderlinge relaties tussen de variabelen zijn weergegeven met behulp van de produkt-moment-correlatie (zie bijlage 4 ).

In de hierna volgende multivariate-analyse, aansluitend op het tweede deel van de probleemstelling, zal worden gezocht naar verklaringen in de variantie van de varlabelen a en $b$ met behulp van de overige variabelen. De variantie die in de steekproef werd gemeten, is natuurlijk slechts voor een gedeelte systematische variantie, waarvan de door ons gebruikte onafhankelijke variabelen mogelijk een gedeelte kunnen verklaren. Een belangrijk deel van de variantie wordt veroorzaakt door meetfouten en toevalsfactoren. Het percentage verklaarde variantie is dan ook noodzakelijkerwijze beduidend minder dan $100 \%$.

Als afhankelijk variabelen worden de relatieve tijdbestedingen genomen van de functies en rubrieken warvan de meetresultaten een variantie bezitten met een relatieve standaarddeviatle $<.75$. Weggelaten worden de rubrieken "telefoon" en "reistijd", omdat deze inhoudelijk niet relevant zijn in het kader van onze probleemstelling. Uit het pakket vragen over de taakopvatting worden de schalen gehanteerd zoals hiervoor onder $d$ tot en met $h$ zijn aangegeven; weggelaten zijn de gegevens over het nut van de voorzieningen. De hoge correla- 
tie tussen de antwoorden op vragen naar het nut en vragen naar het gebruik van voorzieningen zou storende intercorrelaties op gaan leveren in de verdere analyse.

Als structureel kenmerk op gemeenteniveau is alleen de urbanisatiegraad in de verdere analyse betrokken. Andere gegevens die specifiek het voorzieningenniveau betreffen, ook de aanwezigheid en omvang van algemene zlekenhuizen, bleken een zeer hoge samenhang met de urbanisatiegraad te bezitten. In de urbanisatiegraad zijn variabelen als "afstand tot het ziekenhuis" en "aantal gezondheidszorgvoorzieningen" ondergebracht op een wijze die voor het doel van dit onderzoek en gelet op de beperkte omvang van de steekproef voldoende acceptabel kan worden geacht.

De bevolkingsopbouw is alleen geindiceerd met behulp van het aantal "kinderen jonger dan 14 jaar", als ratio op het totaal aantal inwoners. Andere demografische of sociaal-economische bevolkingskenmerken konden niet tegelijkertijd in dezelfde analyse worden betrokken, omdat $\pm 40 \%$ van het aantal geobserveerde huisartsen met twee of meer in eenzelfde gemeente praktizeerde. Correctie voor de hierdoor ontstane kunstmatige hoge samenhang tussen variabelen die op het gemeenteniveau gemeten $z i j n$, leverde onacceptabele reductie van het aantal steekproefeenheden op. Voor het kenmerk van de leeftijdsopbouw is gekozen, omdat hiervan de meest inhoudelijke en uitgebreide informatie bestaat omtrent de samenhang met het bezoek aan de huisarts (Bergsma, 1979). 
HOOFDSTUK 6

VERKLARING VAN VERSCHILLEN IN FUNCTIE-UITOEFENING

\subsection{INLEIDING}

De verklaring van de structurele variantie in de relatieve tijdbesteding aan de onderscheiden groepen van activiteiten, door de variabelen die in het voorafgaande hoofdstuk zijn beschreven, wordt met behulp van regressie-analyse onderzocht (Kerlinger, 1973; Nie e.a., 1974).

Ten behoeve van de hierna volgende multivariate-analyse zal eerst een model, ontleend aan de probleemstelling, worden omschreven. Volgens dit model zullen de achtereenvolgende analysestappen worden uitgevoerd.

\subsection{ANALYSEMODEL}

Wanneer we de probleemstelling formuleren in termen van de gemeten variabelen dan ontstaat de volgende redenering. We stellen dat het klachtenaanbod in kwalitatieve zin in princlpe gelijkelijk verdeeld is voor alle in de steekproef opgenomen huisartsen. Indien vervolgens de huisarts uitsluitend afhankel1 jk van de gepresenteerde klachten zou werken, dan zou slechts variantie in relatieve tijdbesteding per functie ontstaan ten gevolge van toevallige, aan de meting toe te schrijven factoren en het feitelijke geregistreerde aantal patiënten per uur tijdens de observatieperiode (: het gemiddeld patiëntenaanbod). In werkelijkheid zal de relatieve tijdbesteding per functie niet alleen afhankelijk $z i j n$ van de inhoud van de gepresenteerde klachten en het aantal patiënten (Lamberts, 1981).

We veronderste1len:

a) de variantie in relatieve tijdbesteding per functie zal voor een deel te verklaren zijn uit de verschillen in 
taakopvatting omtrent het functioneren als huisarts;

b) de verschillen in het aantal patiënten dat gedurende de observatieperiode door de huisarts werd gezien, zijn voor een deel toe te schrijven aan ervaring van de huisarts, kenmerken van ziljn praktijk en van de gemeente van vestiging;

c) de variantie in takkopvatting van de huisarts is deels toe te schrijuen an dezelfde achtergrondkenmerken, die ook van invloed $z i j n$ op het aantal patiënten waarmee de huisarts contact had tijdens de observatieperiode.

In schema gebracht ontstaat het in figuur 7 weergegeven model.

Figuur 7: Analysemodel met aanduiding van de opeenvolgende regressievergelijkingen

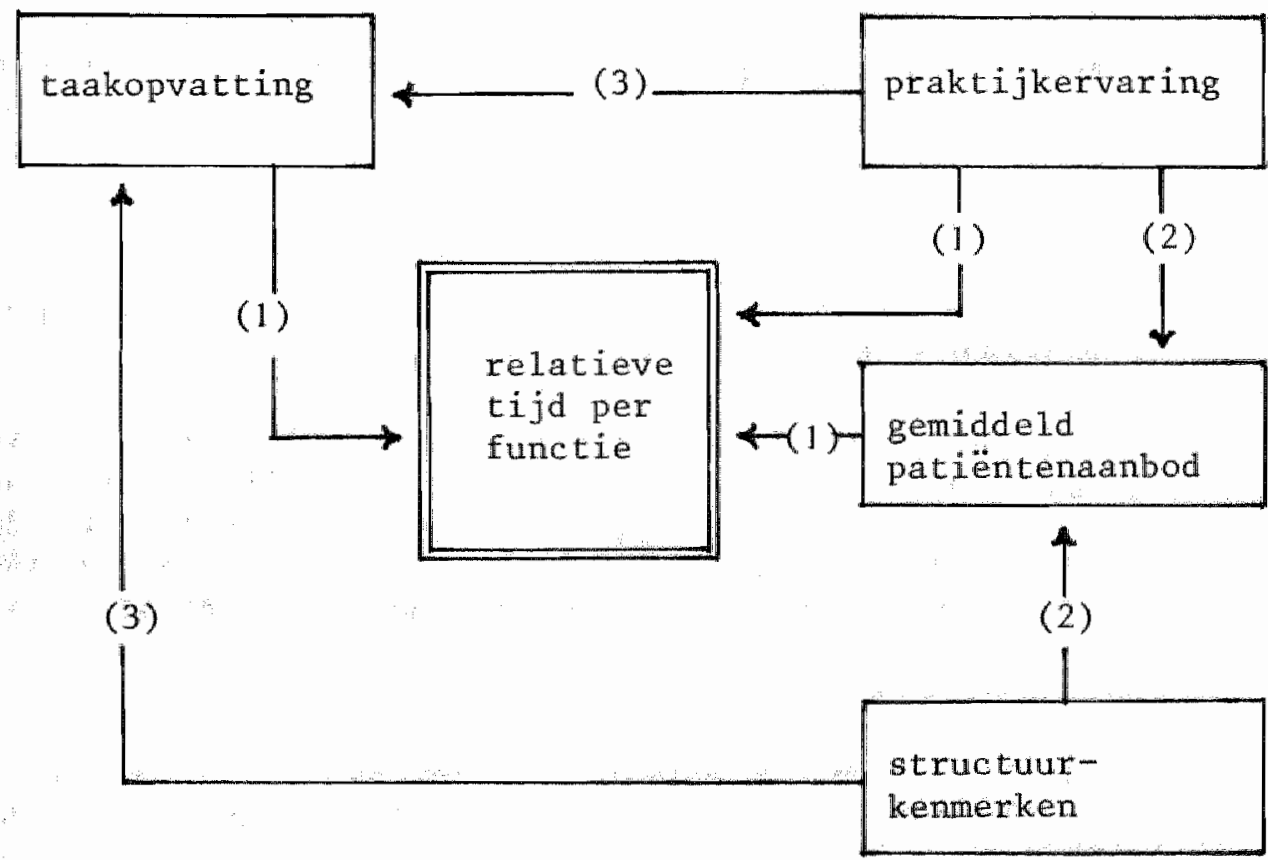


Toellchting: de omschrijving van de variabelen, die in dit model worden gehanteerd, is gegeven in hoofdstuk 5.4 ., onder de volgende letters:

- relatieve tijd per functie: a en b;

- taakopvatting: d tot en met h;

- praktijkervaring: $m$;

- gemiddeld aantal patiënten per uur: e;

- structuurkenmerken: $i, j, k, 1, n$ en 0 .

Met behulp van de pijlen worden de richtingen aangegeven waarin de veronderstelde beinvloeding verloopt. De nummers bij de pijlen geven de afzonderlijke specificaties weer:

(1) verklaring op grond van veronderstelling a; (par.6.3.1.)

(2) verklaring op grond van veronderstelling b; (par. 6.3.2.)

(3) verklaring op grond van veronderstelling $c$; (par.6.3.3.)

Tenslotte kan het stelsel vergelijkingen dat uit de drie specificaties resulteert, gebruikt worden voor de beschrijving van het totale model, en wel door de resultaten uit de specificaties 2 en 3 te voegen in 1 ; anders gezegd: substitutie van de vergelijkingen 2 en 3 in 1 , waardoor het gehele model wordt ingevuld, (par. 6.3.4.)

\subsection{RESULTATEN}

6.3.1. EERSTE SPECIFICATIE: BETEKENIS VAN GEMIDDELD PATIENTENAANBOD, PRAKTIJKERVARING EN TAAKOPVATTING

De invloed die toegeschreven kan worden aan de persoonlijke opvattingen van huisartsen omtrent de vervulling van hum taak en hun praktijkervaring, komt tot uitdrukking in de eerste serie lineaire vergelifkingen, die tevens de afzonderlijke rol van het gemiddeld patiëntenaanbod laat zien.

(In de tabellen 7 tot en met 10 betekent een $\beta^{*}$ dat de bijbehorende F-ratio significant is op het vijf-procents niveau). 
Tabel 7: Verklaring van variantie in relatieve tijabesteding aan "diagnostiek" en "therapie"

diagnostiek

$r$

$-.17$

$-.14$

$-.08$

$-.16 *$

$-.02$

$-.05$

samenwerking

beschikbare tijd en voorzieningen therapie

r

$-.09$

$-.16$

$+.10$

$+.18 *$

Miveau van diagnos-

tiek en therapie

$-.04$

$+.02$

$+.02$

$+.01$

gebruik van voorzieningen

$+.21 *$

$+.04$

$-.08$

gemiddeld patiën-

tenaanbod

$+.51$

$+.43 *$

$+.51$

$+.51 *$

Uit de resultaten blijkt dat "het gemiddeld patientenaanbod" een zeer grote rol speelt bij de verklaring van de variantie in tijdbesteding aan diagnostiek, therapie en condities. Dok verschillen in verwijsproporties blijken, zij het in mindere mate door het gemiddeld patiëntenaanbod voor een significant deel, verklaard te worden. Naarmate het aantal patiënten per uur toeneemt, stijgt de relatieve tijd die besteed wordt aan diagnostiek en therapie, onafhankelijk van alle andere factoren. De porportie verwijzingen neemt echter af bij toenemend gemiddeld patiëntenaanbod. Het aantal verwijzingen is 
Tabel 8: Verklaring van variantie in relatieve tijdbesteding aan "preventie" en "begeleiding"

$\begin{array}{lll}\text { preventie } & & \text { begeleiding } \\ r & B & r\end{array}$

$\begin{array}{lcccc}\text { praktijkervaring } & +.15 & +.11 & +.17 & +.18^{*} \\ \text { taakbreedte } & -.08 & -.12 & -.01 & +.01\end{array}$

bereidheid tot

samenwerking

$\begin{array}{llll}-.01+.03 & -.07 & -.05\end{array}$

beschikbare tijd

en voorzieningen

$+.14$

$+.13$

$+.01$

$-.05$

niveau van diagnos-

thiek en therapie
gebruik van voor-
zieningen

$+.16$

$+.18 *$

$-.09$

$-.11$

$-.10$

$-.10$

$+.01$

$+.01$

gemiddeld patiën-

tenaanbod

$+.07+.11$

$-.04$

$-.05$

verklaarde variantie

.09

.05

in dit onderzoek gemeten in verhouding tot het aantal consulten; vergelijking met verwijscijfers die op andere wijze zijn berekend, is niet zonder meer mogelijk. Als verklaring voor de gevonden samenhang tussen verwijzingen en gemiddeld aantal patiënten per uur, kan men veronderstellen dat een hoger aantal patiënten per uur duidt op relatief meer lichte klachten, ten gevolge waarvan het aantal verwijzingen daalt. omdat we geen informatie over de ernst van de gepresenteerde klacht hebben verzameld, kunnen we onze veronderstelling hier niet toetsen. 
Tabel 9: Verklaring van varlantie in relatieve tijdbesteding aan "condities" en "prive"

$\begin{array}{lll}\text { condities } & \text { privé } \\ \mathbf{r} & \beta & \mathbf{r}\end{array}$

B

$\begin{array}{lllll}\text { praktijkervaring } & -.08 & -.07 & +.15 & +.10 \\ \text { taakbreedte } & +.15 & +.12 & -.01 & -.08\end{array}$

bereidheid tot

samenwerking

$+.35$

$+.36^{*}$

$-.05$

$+.01$

beschikbare tijd

en voorzieningen

$+.19+.14+.25+.22 *$

niveau van diagnos-

tiek en therapie $-.11+-.13+.24+.23 *$

gebruik van voor-
zieningen
$+.01$
$-.02$
$-.22$
$-.27 *$
gemiddeld patiën-
tenaanbod
$-.33$
$-.32 *$
$-.18$
$-.10$

verklaarde variantie

.30

.18

De afnemende relatieve tijd besteed aan "condities" bij toenemend patiëntenaanbod, kan voornamelijk worden toegeschreven aan het ontbreken van tijd voor samenwerking en overleg in het eerste echelon, naarmate het aantal patiënten per uur stijgt.

Taakbreedte blijkt slechts van betekenis bij de verklaring van verschillen in relatieve tijd voor theraple: bredere taakopvatting verklaart een gedeelte van de tijd die ten gevolge daarvan extra an therapie wordt besteed. 
Tabel 10: Verklaring van variantie in aantal "verwijzingen" per 100 consulten

verwijzingen

$r$

B

$\begin{array}{lll}\text { praktijkervaring } & -.22 & -.17 * \\ \text { taakbreedte } & -.01 & +.02\end{array}$

bereidheid tot

samenwerking $+.17+.13$

beschikbare tijd

en voorzieringen

$-.12-.11$

niveau van diagnos-

tiek en therapie $-.24 \quad-.23$ *

gebruik van voor-

zieningen

$+.12+.12$

gemiddeld patiën-

tenaanbod $-.13 \quad-.19$ *

verklaarde variantie:

.17

Praktijkervaring van de huisarts speelt een rol bij diagnostlek, begelelding en verwijzen: naarmate de ervaring toeneemt, wordt relatief minder verwezen, neemt de relatieve tijd voor diagnostiek af en voor begellelding toe (Eisenburg, $1981)$.

Dok het niveau waarop men zegt somatische diagnostiek en therapie te willen uitoefenen als huisarts, heeft enige betekenis: streeft men naar een hoog niveau dan wordt minder verwezen. De huisartsen die een hoger niveau ambiëren, zijn 
bovendien ook degenen die relatief meer tijd aan preventie besteden en meer privé-tijd bezitten.

De twee variabelen: "gebruik van voorzleningen" en "beschikbare tijd en voorzieningen" zijn van een iets ander karakter dan de opvattingen omtrent taakbreedte en -niveau.

De opvatting over "beschikbare tijd en voorzieningen" zegt vooral iets over de wenselijk geachte omstandigheden waaronder de huisarts zijn functies wil uitoefenen en minder over de feitelijke omstandigheden. Het antwoord op de vragen naar het "gebruik van voorzieningen" is gedeeltelijk gebaseerd op het wenselijk of noodzakelijk gebruik, maar geeft ook een meer of minder betrouwbare informatie over het wenselijk gebruik.

Hoewel we beide variabelen consequent als percepties en dus als verklarende variabelen hanteren, is een omgekeerde oorzakelijkheid ook denkbaar, indien een werkelijke situatie wordt beschreven. Meer tijdsdruk en minder aanwezige ondersteunende voorzieningen worden vermeld door huisartsen, die relatief veel tijd aan diagnostiek en therapie besteden en weinig tijd hebben voor privé-activiteiten.

Huisartsen die veel tijd aan diagnostiek en weinig aan privë-activiteiten besteden, zeggen veel gebruik te maken van aanwezige ondersteunende voorzieningen.

Samenvattend:

De eerste specificatile van het analysemodel blijkt redelijk juist te $z i j n$ voor de relatieve tijdbesteding aan de functies "diagnostiek", "theraple" en de rubriek "condities". Het gemiddeld patiëntenaanbod heeft ook enige verklarende betekenis voor verschillen in de proportie verwijzingen, maar speelt geen rol bij de functies "begeleiding" en "preventie"t.

De taakopvatting blijkt, volgens de eerste veronderstelling uit het analysemodel, als verklaring van verschillen in de relatieve tijdbesteding voor alle functies en rubrieken van betekenis. Wanneer "gemiddeld patiëntenaanbod" en "taakopvatting" als variabelen gelijktijdig verklarende betekenis hebben, wordt een totaal verklaarde variantie van $\pm 30 \%$ bereikt; is alleen de laatstgenoende variabele van invloed dan blijft het verklaarde deel van de systematische varlantie rond de $10 \%$. 
6.3.2. TWEEDE SPECIFICATIE: BETEKENIS VAN STRUCTUURKENMERKEN VOOR HET GEMIDDELD PATIENTENAANBOD

De variantie in het gemiddeld aantal patiënten dat de huisarts per uur zag gedurende de observatieperiode, heeft mogelijk meer dan toevallige gronden. Deze kunnen zowel de praktijkstructuur betreffen als de kenmerken van de gemeente van vestiging. We veronderstellen dat deze groepen variabelen van invloed zijn op de relatieve tijdbesteding per functie voorzover ze verklarend zijn voor verschillen in het gemiddeld aanbod van patiënten (specificatie 2, figur 7 ).

Tabel 11: Verklaring van variantie in "gemiddeld patientenaanbod" door middel van: "praktijkervaring" en "structuurkenmerken"

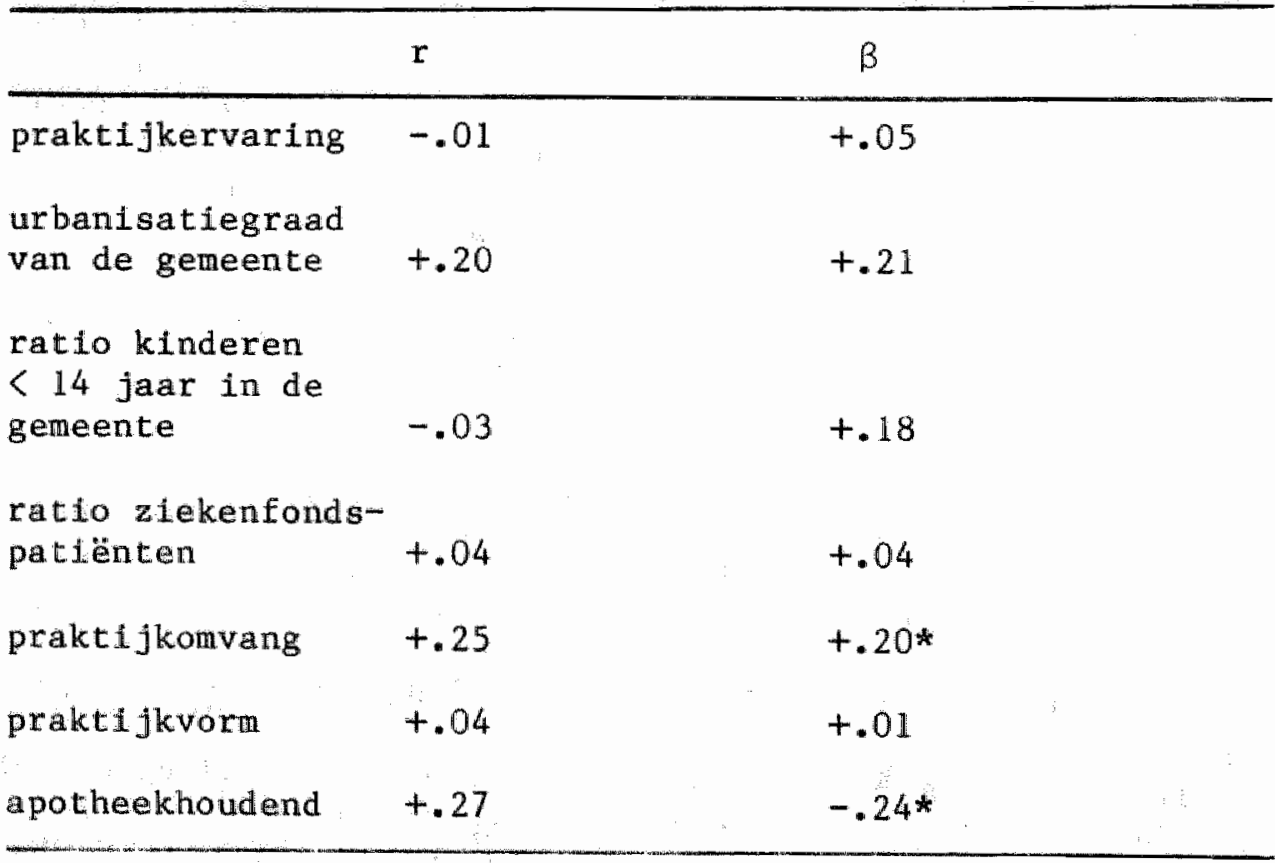

verklaarde variantie:

(Een $\beta^{*}$ heeft een F-ratio die significant is op het vijf-procents niveau). 
De twee kenmerken die een slgnificant verklarende betekenis hebben, zijn praktijkgrootte en het al dan niet apotheekhoudend zijn.

De betekenis van praktijkgrootte is voor de hand liggend: het patiëntenaanbod neemt toe, naarmate de praktijk warin de huisarts werkt groter is. De vraag naar diensten van de huisarts blijkt toe te nemen wanneer het aantal ingeschreven patiënten in zijn praktijk groeit, ongeacht de mogelijke specifieke invloed van bepalde soorten klachten, leeftijdsopbouw van de bevolking, of de aanwezigheid van andere en aanvullende hulpverlenende diensten. Deze vanzelfsprekende relatie wordt niet gevonden door Aulbers en Oliemans (1971). In de door hen getrokken steekproef van 8 praktijken wordt geen duidelijke relatie aangetroffen tussen aantal contacten en praktijkomvang, hetgeen mogelijk veroorzaakt kan worden door de geringe onvang van de steekproef.

Het relatief geringere gemiddelde antal patiënten per uur bij apotheekhoudende huisartsen in vergelijking met nietapotheekhoudende huisartsen, is mogelijk toe te schrijven aan extra tijd, die aan apotheekwerkzaamheden moet worden besteed.

\section{Samenvattend:}

De praktijk- en gemeentekenmerken die in dit onderzoek zijn opgevoerd als mogelijke verklaring voor verschillen in relatieve tijdbesteding per functie, leveren een bijdrage door hun betekenis voor de verschillen in het gemiddeld patiëntenaanbod per huisarts. De praktijkgrootte en het al dan niet houden van een eigen apotheek, blijken van Invloed voor het gemiddeld aantal patiënten per ur dat een beroep doet op de diensten van de huisarts.

6.3.3. DERDE SPECIFICATIE: BETEKENIS VAN STRUCTUURKENMERKEN VOOR DE VERSCHILLEN IN TAAKOPVATTING

In het analysemodel wordt verondersteld dat de structuurkenmerken van invloed zijn op de relatieve tijdbesteding per functie, ofwel door hun betekenis bij verschillen in het gemiddeld patiëntenaanbod (tweede specificatie: 6.3.2.), ofwel door hun rol bij de verklaring van de variantie in de taakopvatting: derde specificatie. 
Tabel 12a: Verklaring van variantie in taakopvatting door middel van "praktijkervaring" en "structuurkenmerken"

\section{taakbreed te}

r

$+.02$

$-.11$

$$
+.07
$$

$+.01$

$+.09$

$-.01$

ratio ziekenfondspatiënten

$$
-.10
$$$$
-.10
$$$$
-.01
$$$$
-.01
$$

praktijkomvang

$-.08$

$-.06$

$+.20$

$+.20 *$

prakti jkvorm.

$-.08$

$-.09$

$-.01$

$+.01$

a po theekhoudend

$+.17$

$+.16$

$+.06$

$+.04$

B1j verklaringen van verschillen in opvattingen omtrent taakbreedte zijn geen van de opgevoerde variabelen van betekenis.

Het niveau warop de huisarts diagnostiek en therapie uitoefent blijkt te stijgen bij toenemende praktijkomvang. Voor de hand 11ggend en reeds vaker aangetoond, is het hogere gebruik dat huisartsen zeggen te maken van voorzieningen, naarmate ze in een gemeente met een hogere urbanisatiegraad praktizeren. 
Tabe1 $12 b$ :

$\begin{array}{lll}\text { bereidheid } & \text { beschikbare } & \text { gebruik van } \\ \text { tot samen- } & \text { tijd en } & \text { voorzienin- } \\ \text { werking } & \text { voorzieningen } & \text { gen }\end{array}$

$r \quad r \quad \beta$

\begin{tabular}{lllll} 
praktijkervaring & $-.09-.08$ & $+.21+.13$ & +.02 & +.07 \\
$\begin{array}{l}\text { urbanisatiegraad } \\
\text { van de gemeente }\end{array}$ & $+.01+.24 *$ & $-.22-.18$ & +.33 & $+.35 *$ \\
$\begin{array}{l}\text { ratio kinderen } \\
<\quad 14 \text { jaar in } \\
\text { de gemeente }\end{array}$ & $+.21+.25 *$ & $+.15-.02$ & -.26 & -.06 \\
$\begin{array}{l}\text { ratio zieken- } \\
\text { fondspatiënten }\end{array}$ & $-.01-.01$ & $-.18-.17 *$ & +.01 & +.04 \\
praktijkomvang & $+.02+.01$ & $+.07+.05$ & +.01 & +.03 \\
praktijkvorm & $+.42+.35 *$ & $-.01+.03$ & +.02 & -.01 \\
apotheekhoudend & $+.20+.24^{*}$ & $+.20+.07$ & -.11 & +.08 \\
\hline
\end{tabular}

verklaarde variantie $\quad .25 \quad .11 \quad .12$

(Een $\beta$ * heeft een F-ratio die significant is op het vijfprocents niveau).

Tijdsdruk en gebrek aan voorzleningen wordt meer ervaren naarmate proportioneel meer ziekenfondspatiënten in de praktijk aanwezig zijn (Van Vilet en Van der Ven, 1982). De bereidheid tot samenwerking in het eerste echelon, die van betekenis is voor de verklaring van de variantie in de relatieve tijdbesteding aan "diagnostiek" en "condities", blijkt vooral aanwezig bij huisartsen in de meer ge-urbaniseerde gemeenten, de samenwerkende en apotheekhoudende artsen, en in praktijkgemeenten met een relatief groot aantal kinderen 
in de bevolkingssamenstelling. Een verklaring van deze samenhangen is waarschijnlijk gelegen in de wijze waarop de praktijken van de samenwerkende huisartsen gespreid zijn over de gemeenten.

Samenvattend:

De verklarende betekenis van de structuurkenmerken voor de variantie in de taakopvattingen blijkt van geringe omvang. De opvattingen over de breedte en het somatisch-technisch niveau van de taken die de huisartsen zich gesteld zien, blifken niet beinvloed te worden door de kenmerken van hun praktijk of de gemeente warin ze praktizeren. De "bereidheid tot samenwerking" speelt een aparte rol, voornamelijk door het enigszins contaminerende effect van de feitelijke praktijkvorm en de vestigingsplaats hiervan.

\subsubsection{SAMENGEVOEGDE SPECIFICATIES}

De afzonderlijke betekenis van de verschillende variabelen voor de verklaring van de relatieve tijdbesteding per functie en rubriek van activiteiten, wordt verkregen door de resultaten van de regressie-analyse, die verkregen zijn in de specificaties 2 en 3 , in te vullen in de eerste vergelijking van het analysemodel. Dit betekent dat de indirecte werking van de structuurkenmerken wordt uitgedrukt in hun verklarend effect op de variantie in de relatieve tijdbesteding per onderscheiden groep activiteiten. Omdat de variabele "praktifkervaring" geen significante verklaringen bleek op te leveren voor de variantie in tijdbesteding langs de veronderstelde indirecte weg (zie tabel 11 en 12), is deze in de tabellen $13 \mathrm{a}$ en $13 \mathrm{~b}$ niet opgenomen.

De relatieve tijd die besteed is an "begeleiding", wordt door geen van de onafhankelijk variabelen met indirecte werking verklaard; in de tabel 13a stat deze functie dan ook nlet vermeld. 
Tabel 13a: Verklaring van variantie in relatieve tijdbesteding aan "diagnostiek", "therapie, "preventie"

$\begin{array}{ccc}\text { diagnostiek } & \text { therapie } & \text { preventle } \\ \beta & \beta & \beta\end{array}$

urbanisatiegraad

van de gemeente +.03

ratio kinderen

$<14$ jaar in de

gemeente

$-.04$

ratio zieken-

fondspatiënten

prakti jkomvang

$+.09$

$+.10$

$+.04$

praktijkvorm

$-.06$

apotheekhoudend

$-.14$

$-.12$

(N.B. alleen de B-coefficiënten met een significante F-ratio op vijf-procents niveau zijn gebruikt bij de substitutie).

Opmerkelijk is de rol die de praktijkonvang speelt. De relatieve tijd die besteed wordt aan "dlagnostiek" en "therapie" neemt toe bij groter wordende praktijkomvang; de relatieve tijd die aan "condities" wordt besteed daalt bij toenemende praktijkgrootte en het aantal verwijzingen per 100 consulten neemt af, (Van Duuren, 1981). Deze resultaten komen voort uit de betekenis die de praktijkgrootte heeft voor het gemiddeld patientenaanbod (zie specificatie 2 in $6.3 .2)$. Het toenemen van de relatieve tijdbesteding aan "preventie" en "privé" naarmate in een grotere praktijk wordt gewerkt, ontstaat door het verband tussen "niveau" en "praktijkomvang" (zie specificatie 3 in 6.3.3). Een mogelijke verklaring hiervoor is niet zonder meer te geven. 
Tabel 13b: Verklaring van variantie in relatieve tijdbesteding aan "condities", "prive", en in proportie "verwijzingen"

\begin{tabular}{|c|c|c|c|}
\hline & $\underset{B}{\text { Condities }}$ & $\underset{\beta}{\operatorname{Pr} 1 \text { vê }}$ & $\begin{array}{l}\text { Verwijzingen } \\
B\end{array}$ \\
\hline $\begin{array}{l}\text { urbanisatlegraad } \\
\text { van de gemeente }\end{array}$ & +.09 & -.09 & - \\
\hline $\begin{array}{l}\text { ratio kinderen } \\
<14 \text { jaar in de }\end{array}$ & & & \\
\hline gemeente & +.09 & - & - \\
\hline ratio zieken- & & & \\
\hline fondspatiẻnten & - & - & - \\
\hline praktijkomvang & -.06 & +.05 & -.09 \\
\hline praktijkvorm & +.13 & - & - \\
\hline apotheekhoudend & +.01 & - & +.05 \\
\hline
\end{tabular}

(N.B. alleen de $\beta$-coefficiënten met een significante F-ratio op vijf-procents niveau zijn gebruikt bij de substitutie).

De andere relaties die in tabe1 $13(a, b)$ zijn aangegeven,

leveren verder geen interpretatieproblemen op. We volstaan met hieruit slechts de rol te lichten die gespeeld wordt door het als huisarts al of niet hebben van een eigen apotheek. De apotheekhoudende huisarts ziet een duidelijk geringer aantal patienten per uur, waardoor de relatileve tijdbesteding aan diagnostiek en therapie geringer wordt dan bij zijn niet-apotheekhoudende collegae. In de discussies tussen de voor - en tegenstanders van apotheekhoudende huisartsen is de relatie met het gemiddeld patientenaanbod nog niet betrokken (Bosch, 1982). 


\section{Samenvattend:}

De verklarende betekenis voor verschillen in relatieve tijdbesteding die door de "structuurkenmerken" wordt geleverd, verloopt via het gemiddeld aantal patienten per uur ofwel via de opvattingen omtrent huisartsentaken. Vanuit deze veronderstelling uit het analysemodel wordt hun relatieve bijdrage geformuleerd door substitutie van de resultaten uit de eerdere vergelijkingen (tabel 11 en tabe1 12) in de eerste vergelijking (tabel 10). De richting warin de structurele variabelen werkzaam zijn, levert geen interpretatieproblemen. Bijzondere aandacht verdient de variabele "praktijkomvang" waarvan de veronderstelde invloed via het gemiddeld patiëntenaanbod de meest duidelijke blijkt te zijn van het gehele pakket structuurgegevens.

\subsection{CONCLUSIES}

De tot zover uitgevoerde analyse volgens het model zoals in figuur 7 aangegeven, levert het volgende algemeen beeld.

De verschillen in relatieve tijdbesteding per functie die werden gemeten tijdens de observatieperiode, zijn voor een gedeelte te verklaren door middel van de verzamelde gegevens omtrent de huisarts, zijn takopvatting en zijn werksituatie. Het gedeelte dat verklaard wordt verschilt sterk per afzonderlijke functie.

Het hoogste percentage verklaarde variantie wordt gevonden bij activiteiten die verricht worden ten behoeve van "diagnostiek" "therapie" en "condities". Bij deze drie groepen van activiteiten worden de verschillen voor ongeveer ến derde deel verklaard, waarbij in het bijzonder het gemiddeld patiëntenaanbod een doorslaggevende rol speelt.

Toenemend gemiddeld aantal patiënten per uur heeft meer relatieve tijdbesteding aan "diagnostiek" en "therapie" tot gevolg en afnemende tijdinvestering in "condities". De gemeten gevoelens van tijdsdruk en gebrekkige ondersteuning door voorzieningen nemen eveneens toe naarmate het gemiddeld patiëntenaanbod stijgt. Wanneer structuurkenmerken van praktijk en gemeente van vestiging worden beschouwd als mogelijke verklaring voor verschillen in gemiddeld patiëntenaan- 
bod en taakopvatting, blifken alleen de praktijkomvang en het al dan niet houden van een eigen apotheek van betekenis te zijn. In de grotere, niet-apotheekhoudende praktijken wordt door de huisarts relatief veel tijd aan"diagnostiek" en "theraple" besteed, weinig aan "condities", onder de invloed van tijdsdruk en het ontbreken van voldoende ondersteunende voorzlenfingen, bij een hoog gemiddeld aantal patiènten per uux.

Minder variantie wordt verklaard in de proportie verwijzingen blinen de gezondheidszorg per 100 consulten.

Minder "verwijzingen" komt op rekening van een grotere ervaring en het streven naar een relatief hoog niveau van somatische diagnostiek en therapie in eigen praktijk. Naarmate echter het gemiddeld aantal patiënten per uur stijgt, daalt de proportie verwijzingen; aannemelijk is dat relatief lichte klachten een gemiddeld hoog aantal patiënten per uur mogelijk maakt en een daarmee samenhangend verhoudingsgewijs gering aantal verwijzingen. Omdat ons onderzoek geen gegevens over de ernst van de gepresenteerde klachten bevat kan echter ook een andere verklaring worden geformuleerd: naarmate de huisarts meer tijd heeft voor iedere afzonderlijke patiënt is hij meer geneigd tot diepgaande diagnostiek en uitgebreide therapie. Ten gevolge hiervan ontstaat een groter aantal verwijzingen.

De juistheid van de genoemde interpretaties kan niet nader worden onderzocht met behulp van onze onderzoekgegevens.

De verschillen in relatieve tijdbesteding aan activiteiten ten behoeve van "preventie" en "begeleiding" zijn slechts beperkt verklaarbaar met de door ons gehanteerde kenmerken. B1j "begelelding" kan slechts één aanwijzing worden gevonden en wel dat huisartsen meer begeleidend werken naarmate hun praktijkervaring stijgt.

Bif "preventie" wordt alleen geconstateerd dat wanneer een hoog niveau van somatische diagnostlek en theraple wordt nagestreefd, dit gepaard gat met een groter aantal preventieve activitelten. 
opmerkelijk voor beide laatstgenoemde functies is het ontbreken van een relatie met het gemiddeld patiëntenaanbod. Weliswaar leidt een hoger gemiddeld aantal patiënten per uur tot een relatief grotere tijdbesteding aan "diagnostiek" en "therapie". Vermindering van het gemiddeld patiëntenaanbod heeft echter niet tot gevolg dat de relatieve tijd die wordt besteed aan "begeleiding" of "preventie" toeneemt.

Ook de structuurvariabelen die in ons onderzoek zijn gehanteerd hebben vrijwel geen verklarende betekenis voor verschillen in relatieve tijdbesteding aan de functies "begeleiding" en "preventie".

De relatieve tijdbesteding aan "prive" vertoont geen directe relatie met het gemiddeld patiëntenaanbod. Meer privé-tijd gaat samen met de volgende opvattingen over de taakultoefening: grotere beschikbaarheid van tijd en voorzieningen, minder gebruik van voorzieningen en hoger gewenst niveau van somatische diagnostiek en therapie.

Bij de interpretatie van de samenhangen met de relatieve tijd die aan prive-activiteiten wordt besteed, kan deze rubriek beschouwd worden als onafhankelijk variabele, gelet op het rest-karakter ten opzichte van de vorige functies. 
Figuur 8: Schematisch overzlcht van de meest belangrijke relaties tussen de functie-ultoefening, de taakopvatt1ng, en de achtergrondkenmerken

Taakopvatting:

Relatieve tijd voor:

Achtergrondkenmerken:

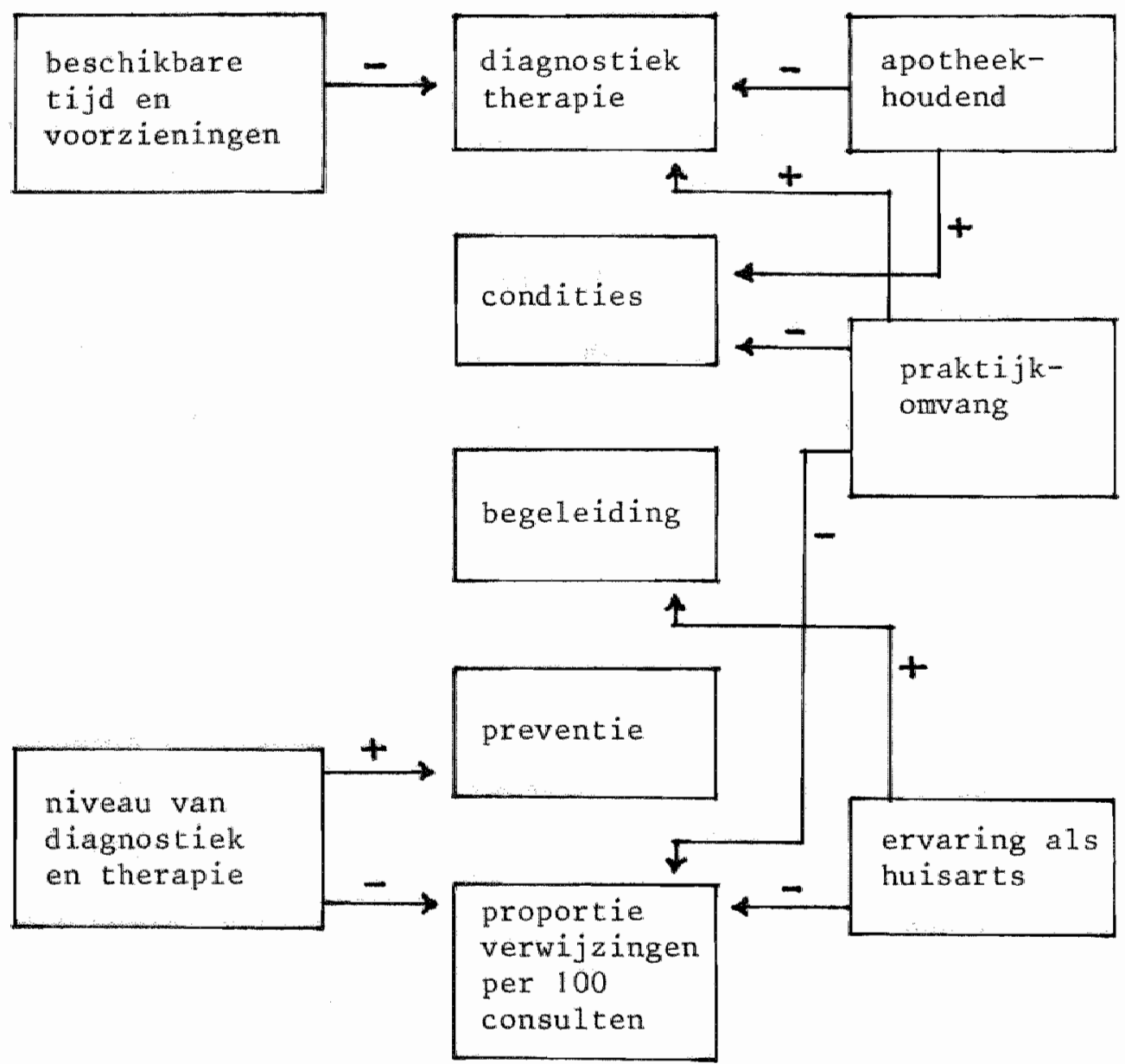


HOOFDSTUK 7

BETEKENIS VAN DE TAAKOPVATTING NADER ONDERZOCHT

\subsection{INLEIDING}

In het voorafgaande hoofdstuk is geconstateerd dat een verband tussen breedte van taakopvatting en uitoefening van functies niet significant aantoonbaar 1s. Gezien de belangrijke plaats die in onze onderzoeksopzet is toegekend an de taakopvattingen en gelet op de vele discussies in en buiten de beroepsgroep over de gewenste breedte van de huisartsentaak, willen we de betekenis van deze variabele nader onderzoeken. Daartoe splitsen we de onderzochte groep huisartsen in tweeën: de groep met een relatief smalle en de groep met een relatief brede taakopvatting. Binnen deze afzonderlijke groepen gaan we na in welke mate de relaties die in hoofdstuk 6 onderzocht $\mathrm{zijn}$, worden gespecificeerd.

Deze werkwijze heeft als nadelen dat de aantallen per groep klein zijn om met behulp van regressie-analyse te worden onderzocht en bovendien dat de oorspronkelijke ordinale schaal waarop de taakopvatting gemeten is, wordt gereduceerd tot een dichotomie. Beide nadelen wegen niet op tegen het voordeel dat een analyse in de groepen met smalle of brede taakopvatting, nadere aanwijzingen kan verstrekken. Deze kunnen betrekking hebben op de relaties die in de lineaire regressie-analyse - warin de variabele taakbreedte was opgenomen - niet (meer) voorkomen, als ook de daarin gevonden relaties nader preciseren ten behoeve van de interpretatie.

Allereerst zal de regressie-analyse worden uitgevoerd volgens de eerste specificatie van het analysemodel (figuur 7 ) binnen iedere groep afzonderlijk. Vervolgens zullen ook de analysestappen (2) en (3) worden gezet in deze groepen, waarbij telkens wordt bezlen of nieuwe verbanden worden gevonden, dan wel reeds bekende worden gespecificeerd. We veronderstellen dat de breedte van de takopvatting een inter- 
veniërende rol speelt. Dit kan blijken doordat een gevonden samenhang in de gehele groep huisartsen door de splitsing in subgroepen wordt gespecificeerd. Ook is het mogelijk dat we in de analyse in de subgroepen relaties aantreffen tussen verklarende en te verklaren variabelen, die in de analyse van de gehele groep niet werden gevonden omdat deze in de twee onderscheiden subgroepen in "tegengestelde richting" werkzaam zijn.

Naast de analyse binnen de subgroepen is een afzonderlijke regressie-analyse uitgevoerd in de gehele groep huisartsen, waarbij de onderscheiding tussen relatief brede of smalle taakopvatting door middel van dummyvariabelen is aangebracht. Uit deze laatste analyse resulteren de aanwijzingen voor significante verschillen tussen de $\beta$-coëficienten in de onderschelden groepen. Deze significanties op het vijfprocent niveau zijn in de volgende tabellen aangegeven door middel van onderstreping van de betreffende coëfficiënten.

\subsection{SPECIFICERING VAN DE VERKLARINGEN}

De splitsing in subgroepen naar taakopvatting levert geen verschillen op in volgorde van de hoeveelheid verklaarde variantie per functie en rubriek. Ook nu blijkt dat ongeveer één derde deel van de verschillen in relatieve tijdbesteding aan "diagnostiek", "therapie" en aan "condities" kan worden verklaard in de afzonderlijke subgroepen.

(In de tabellen 14 t/m 22 behoort bij de $\beta$ * een F-ratio die significant is op het vijf-procents niveau; de onderstreepte $\beta^{\prime} s$ zijn significant verschillend op ditzeifde niveau). 
Tabel 14: Verklaring van verschillen in relatieve tijdbesteding aan "diagnostiek", vergeleken voor huisartsen met relatief smalle of brede takopvatting

alle

huisartsen

$\beta$ relatieve taakopvatting smal

B. breed

$\beta$

\section{praktijkervaring \\ bereidheid tot}

$-.14 *$

$-.12$

$-.11$

samenwerking

$-.16 *$

$-.27 *$

$-.07$

beschikbare tijd

en voorzieningen

$-20 *$

$-.06$

$-.32 *$

niveau van

diagnostiek

en therapie

$+.02$

$+.06$

$-.10$

gebruik van

voorzieningen

$+.21 *$

$+.27 *$

$+.20 *$

gemiddeld

patiëntenaanbod

$+.43 *$

$+.54 *$

$+.38 *$

totaal verklaarde variantie .39 .42 .40

Een opmerkelijke specificatie treedt op: het gemiddeld aantal patiënten per uur heeft weliswaar als voornaamste verklarende factor in beide groepen een gelijk gericht effect, maar in de groep met relatief brede taakopvatting is deze betekenis voor alle functies geringer van omvang. ook de verklaring van verschillen in het gemiddeld aantal patiënten per uur geeft een dergelijk beeld; "praktijkomvang" en "apotheekhoudend" hebben een gelijk gerichte, maar 
Tabe1 15: Verklaring van verschillen in relatieve tijdbesteding aan "therapie" vergeleken voor huisartsen met relatief smalle of brede taakopvatting

a11e

huisartsen

B.

relatieve taakopvatting smal breed

B

prakt1jkervaring

$-.16$

$-.01$

$-.05$

bereidheid tot

samenwerking

$-.05$

$-.04$

$-.05$

beschikbare tijd en voorzieningen

$$
-.17 *
$$

$+.14$

$-.37 *$

niveau van

diagnostiek

en therapie

$$
+.01
$$

$+.03$

$-.04$

gebruik van

voorzieningen

$-.08$

$-.04$

$-.11$

gemiddeld

patiëntenaanbod

$$
+.51 *
$$

$+.66 *$

$+.46 *$

totaal verklaarde variantle

verschillende mate van betekenis. In de groep met relatief brede taakopvatting wordt het gemiddeld patiëntenaambod in geringere mate door belde factoren verklaard dan in de groep met relatief smalle taakopvatting.

Voor de ervaren tijdsdruk en het gebrek aan voorzieningen geldt een omgekeerde speciflcering: juist in de groep met een relatief brede taakopvatting wordt de meeste tijdsdruk gevoeld en worden de aanwezige voorzieningen als onvoldoende ondersteunend beschouwd. 
Tabel 16: Verklaring van verschillen in relatleve tijdbesteding aan "begeleiding" vergeleken voor huisartsen met relatief smalle of brede taakopvatting

$\begin{array}{lcc}\text { alle } & \text { relatieve taakopvatting } \\ \text { huisartsen } & \text { smal } & \text { breed } \\ \beta & \beta & \beta\end{array}$

praktijkervaring

$+.18^{*}$

$+.20$

$+.14$

bereidheid tot

samenwerking

$-.05$

$-.09$

$-.03$

beschikbare tijd

en voorzieningen

$$
-.05
$$

$-.16$

$-.02$

niveau van

diagnostiek

en therapie

$-.11$

$+.11$

$-.30 *$

gebruik van

voorzieningen

$+.01$

$-.02$

$+.07$

gemiddeld

patiëntenaanbod

$-.05$

$-.03$

$-.17$

totaal verklaarde de variantie

ook de algemene verklaring van verschlllen in de proportie verwijzingen krijg een specificering: de eerder gevonden samenhang tussen een hoog verwijspercentage en een laag niveau van diagnostiek en therapie en een laag gemiddeld patiëntenaanbod, treedt met name op in de groep met relatief smalle taakopvatting. De richting van de verklaring door de twee latstgenoende factoren is in de groep met bredere taakopvatting wellswaar gelijk, maar de betekenis is minder. 
Tabel 17: Verklaring van verschillen in relatieve tijdbesteding aan "preventie" vergeleken voor huisartsen met relatief smalle of brede taakopvatting

alle

hulsartsen

$\beta$ relatieve taakopvatting sma1 $\beta$ breed

$\beta$

praktijkervaring

$+.11$

$\underline{-.11}$

$+.25 *$

bereidheid tot

samenwerking

$$
+.03
$$

$+.25$

beschikbare t1jd

en voorzieningen

$+.13$

$+.09$

$+.10$

niveau van

diagnostiek

en therapie

$+.18^{*}$

$+.27 *$

$+.14$

gebruik van

voorzieningen

$-.10$

$-.12$

$-.17$

gemiddeld

patiëntenaanbod

$+.11$

$+.01$

$+.17$

Lotaal verklaarde de variantie .09 .14 .14

De relatieve tijd die huisartsen aan privé-activiteiten besteden, blijkt ook voor de verklaarde verschillen gespecificeerd te worden door de splitsing in groepen. Veel gebruik maken van voorzleningen in combinatie met relatief weinig prive-tijd, treedt met name op in de groep met relatief brede taakopvatting. 
Tabel 18: Verklaring van verschillen in relatieve tijdbesteding aan "condities" vergeleken voor huisartsen met relatief smalle of brede takopvatting

\begin{tabular}{|c|c|c|c|}
\hline & $\begin{array}{l}\text { alle } \\
\text { huisartsen } \\
\qquad B\end{array}$ & $\begin{array}{l}\text { relatieve } \\
\text { smal } \\
\beta\end{array}$ & $\begin{array}{c}\text { taakopvatting } \\
\text { breed } \\
B\end{array}$ \\
\hline praktijkervaring & -.07 & +.07 & -.09 \\
\hline $\begin{array}{l}\text { bereidheid tot } \\
\text { samenwerking }\end{array}$ & $+.36 *$ & $+.39 *$ & $+.38 *$ \\
\hline $\begin{array}{l}\text { beschikbare tijd } \\
\text { en voorzieningen }\end{array}$ & +.14 & +.20 & +.10 \\
\hline $\begin{array}{l}\text { niveau van } \\
\text { diagnostiek } \\
\text { en therapie }\end{array}$ & -.13 & $-.23^{*}$ & -.05 \\
\hline $\begin{array}{l}\text { gebruik van } \\
\text { voorzieningen }\end{array}$ & -.02 & +.11 & -.14 \\
\hline $\begin{array}{l}\text { gemiddeld } \\
\text { patiëntenaanbod }\end{array}$ & $-.32 *$ & $-.48 *$ & -.15 \\
\hline $\begin{array}{l}\text { totaal verklaarde } \\
\text { variantie }\end{array}$ & .30 & .48 & .22 \\
\hline
\end{tabular}

Samenvattend:

Splitsing in twee subgroepen naar de breedte van de taakopvatting geeft een specificering van de eerder gevonden algemene tendens in de verklaring van verschillen in de relatieve tijdbesteding per functies en rubrieken.

De huisartsen met relatief smalle taakopvatting worden bij de uitvoering van de activiteiten ten behoeve van diagnostiek, therapie, praktijkorganiatie en -administratie en 
Tabe1 19: Verklaring van verschillen in relatieve tijdbesteding aan "privê" vergeleken voor huisartsen met relatief smalle of brede taakopvatting

alle

huisartsen

$\beta$ relatieve taakopvatting smal $\beta$ breed

B

praktijkervaring

$+.10$

$-.01$

$+.14$

bereldheid tot

samenwerking

$+.01$

$+.08$

$-.02$

beschikbare tijd en voorzieningen

$+.22 *$

$-.08$

$+.41 *$

niveau van

diagnostiek

en therapie.

$+.23 *$

$+.29 *$

$+.27 *$

gebrulk van

voorzleningen

$-.27 *$

$-.14$

$-.24 *$

gemiddeld

patiëntenaanbod

$-.10$

$-.18$

$-.07$

totaal verklaarde

variantie

.18

.11

$+.35$

verwifzen, meer beinvloed door het gemiddeld patiëntenaanbod dan de huisartsen met een bredere takopvatting. Bij deze laatsten speelt de ervaren druk ten gevolge van gemis aan t1jd en voorzleningen een grotere rol. of met andere woorden: de hulsarts met de relatief brede taakopvatting is wat minder afhankelijk van het aantal patiënten dat hij per uur moet "verwerken"; hij werkt meer volgens elgen inzichten in de huisartsentaken, maar komt in voortdurende tijdnood. 
Tabel 20: Verklaring van verschillen in proportie "verwijzïngen" vergeleken voor huisartsen met relatief smaile of brede taakopvatting

\begin{tabular}{|c|c|c|c|}
\hline & $\begin{array}{l}\text { alle } \\
\text { huisartsen } \\
\quad \beta\end{array}$ & $\begin{array}{l}\text { relatieve } \\
\text { smal } \\
\beta\end{array}$ & $\begin{array}{c}\text { taakopvatting } \\
\text { breed } \\
\beta\end{array}$ \\
\hline praktijkervaring & $-17 *$ & -.02 & -.23 \\
\hline $\begin{array}{l}\text { bereidheid tot } \\
\text { samenwerking }\end{array}$ & +13 & +.20 & +.09 \\
\hline $\begin{array}{l}\text { beschikbare tijd } \\
\text { en voorzleningen }\end{array}$ & -.11 & +.01 & -.19 \\
\hline $\begin{array}{l}\text { niveau van } \\
\text { diagnostiek en } \\
\text { therapie }\end{array}$ & $-.23 *$ & $=.33 *$ & -.19 \\
\hline $\begin{array}{l}\text { gebruik van } \\
\text { voorzieningen }\end{array}$ & +.12 & +.13 & +.15 \\
\hline $\begin{array}{l}\text { gemiddeld } \\
\text { patiëntenaanbod }\end{array}$ & $-.19 *$ & $-.32 *$ & -.13 \\
\hline $\begin{array}{l}\text { totaal verklaarde } \\
\text { variantie }\end{array}$ & .17 & .29 & .16 \\
\hline
\end{tabular}

Dit gaat ten koste van zijn privé-tijd en heeft als gevolg een groter gebruik van de overige gezondheldszorgvoorzieningen. De praktijkgrootte en het al dan niet hebben van een eigen apotheek speelt voor deze arts geen rol bij de verklaring van verschillen in het gemiddeld aantal patiënten per uur. 
Tabe1 21: Verklaring van verschillen in "gemiddeld patiëntenaanbod "vergeleken voor huisartsen met relatief smalle of brede taakopvatting

alle

hulisartsen

B relatieve taakopvatting smal

$\beta$

$+.11$

$-.02$

praktijkervaring

$+.05$

$+.21$

$+.17$

$+.30$

urbanisatiegraad

van de gemeente

ratio kinderen

$<14$ jaar in de gemeente

prakt: jkomvang

$$
+.18
$$

$+.22$

$+.14$

$+.20 *$

$+.33 *$

$+.12$

ratio zieken-

fonds patıënten

prakt 1 jkvorm

apo theekhoudend

totaal verklaarde variantie
.15
.16

Men kan veronderstellen dat huisartsen met een relatief brede taakopvatting een meer bewuste en eigen stellingname ten aanzien van hun taken bezitten, meer los komen van het patiëntenaanbod. Deze andere opstelling kan niet aan structurele omstandigheden die in dit onderzoek zifn gebruikt, toegeschreven worden. Nader onderzoek zal nodig zijn om de waarschijnlijk meer betekenisvolle persoonlijke kenmerken van huisartsen voor de verschillen in breedte van de taakopvatting te achterhalen. 


\subsection{TEGENGESTELDE RICHTINGEN}

Wanneer we de splitsing in groepen naar de breedte van de taakopvatting bezien, dan zijn enkele tegengestelde richtingen van verklarende relaties opvallend.

Allereerst de betekenis van de ervaren tijdsdruk en het gebrek aan voorzieningen, voor de verklaring van verschillen in tijdbesteding aan therapie. Zoals hiervoor reeds werd vermeld, is de groep huisartsen met een relatief brede taakopvatting meer door deze variabele gekenmerkt dan door het gemiddeld patiëntenaanbod. Bij de relatieve tijdbesteding aan therapie komt dit het meest duidelijk naar voren. Ondanks de positieve samenhang tussen de relatieve hoeveelheid tijd die aan therapie wordt besteed en de ervaren beschikbaarheid van tijd en voorzieningen bij de groep met een relatief smalle taakopvatting, blijkt dat de coëfflciënt voor de gehele groep negatief is. In de groep huisartsen met relatief brede taakopvatting valt een sterke negatieve samenhang te constateren tussen de ervaren beschikbaarheld van tijd en voorzieningen en de relatieve tijdbesteding aan therapie.

Deze vaststelling versterkt de in paragraaf 7.2 . beschreven typering van artsen met een relatief brede taakopvatting.

Bij de activiteiten in het kader van "begeleiding" en "preventie" treden eveneens twee opmerkelijke tegensteliingen op, wellswaar met een geringer algemeen effect. Huisartsen in de groep met relatief brede taakopvatting blijken meer tijd aan preventie-werkzaamheden te gaan besteden naarmate hun praktijkervaring toeneemt, dit in tegenstelling tot hun collegae met relatief smalle taakopvatting.

Toenemen van begeleidingstijd gat in de groep met relatief brede taakopvatting samen met een afnemende ambitie om theraple en diagnostiek op somatisch-technisch hoog niveau te willen uitoefenen; tegengesteld aan de contrasterende groep.

Samenvattend:

De huisarts met relatief brede taakopvatting ondervindt meer de tijdsdruk en het gebrek aan ondersteunende voorzleningen bij toenemende relatieve tijdbesteding aan therapie; gaat naarmate $z i j n$ ervaring toeneemt meer tijd aan preventie besteden; kiest voor meer begeleiding van zijn patiënten bij 
een lager technisch niveau van diagnostiek en therapie. Dok hiler past het beeld van de meer bewuste stellingname van de huisarts ten anzien van de hem toebedachte en/of opgedrongen werkzaamheden. De bewuste keuze leidt tot verschillen in functevervulling, los van de feltelijke patiëntenstroom.

\subsection{STRUCTURELE VERSCHILLEN}

Evenals in het algemene analysemodel bezien we ook nu afzonderlijk de mogelijke betekenis van de structurele kenmerken voor de verschilien in opvattingen over het werken als huisarts, gesplitst naar de groepen zoals hiervoor aangegeven.

Een hoog niveau van somatische diagnostiek en therapie biljkt in de groep met de relatief bredere taakopvatting samen te gaan met een grotere praktijkomvang.

In deze zelfde groep huisartsen is de bereidheid tot samenwerking groter naarmate men in een meer geürbaniseerd gebied praktizeert, evenals wanneer de gemeente van vestiging een relatief jonge bevolking bezit. Tevens gat de huisarts met relatief brede taakopvatting wat minder gebukt onder de druk van het gebrek aan tijd en voorzieningen naarmate zijn ervaring toeneemt, en wanneer hij werkzaam is in een gestructureerd samenwerkingsverband. Het gebruik dat gemaakt wordt van de gezondheldszorgvoorzleningen door deze huisarts is niet afhankelijk van de urbanisatiegraad van de gemeente van vestiging. Dit alles in tegenstelling tot de groep huisartsen met een relatief smallere taakopvatting. De samenhang tussen de urbanisatiegraad van de praktijkgemeente en het al dan nlet houden van een apotheek, speelt bij de splitsing in de twee subgroepen naar breedte van taakopvatting een storende rol in de regressie-analyse. Een interpretatie van de betekenls van het al dan niet apotheekhoudend $z 1 j n$, wordt in dit verband dan ook achterwege gelaten. 
Tabe1 22a: Verklaring van verschillen in taakopvatting door middel van structurkenmerken, vergeleken voor huisartsen met relatief smalle of brede taakopvatting

niveau van diagnostiek en therapie

Breedte van taakopvatting

alle smal breed huis-

artsen

$\beta$

$+.01+.12-.05$

$-.08$

$-.04-.12$

praktijkervaring

urbanisatiegraad gemeente van vestiging $-.06-.04-.10+.24 *+.16 \pm+.33 *$
$+.20 * \pm .01+.31 *+.01+.15-.06$

praktijkomvang

ratio ziekenfond spatiënten $\begin{array}{llll}-.01 & -.03 & -.04\end{array}$ $-.01$ $-.10+.04$

ratio kinderen $<14$ jaar in de gemeente van vestiging $-.01+.22-.14$ $+.25 *+.13 \pm .31 *$ apotheekhoudend $+.04-.18+.16$ $+.24 *+.08+.31 *$ samenwerkende praktijkvorm $+.01-.10+.06$ $+.35 *+.44 *+.32 *$

totaal verklaarde variantie .05 $.07 \quad .09$ $.25 \quad .25$ 
Tabel 22b: Verklaring van verschillen in taakopvatting door middel van structuurkenmerken, vergeleken voor huisartsen met relatief smalle of brede taakopvatting

beschikbare tijd

en voorzieningen gebrulk van voorzieningen
Breedte van taakopvatting alle smal breed huis artsen

$\beta$

urbanisatiegraad gemeente van vestiging $-.18-.06-.21$ $+.35 *+.51 *+.24$

praktijkomvang $+.05+.16-.09$ $+.03$ $+.11+.02$

ratio ziekenfondspatiënten

$$
\begin{array}{llllll}
-.17 & -.06 & -.11 & +.04 & -.04 & +.09
\end{array}
$$

ratto kinderen $<14$ jaar in de gemeente van vestiging $-.02-.18+.14$ $-.06-.13+.01$ apotheekhoudend $+.07+.36 *-.20+.08+.08-.02$ samenwerkende praktijkvorm $+.03 \quad-.12 \quad+.27 *-.01-.10+.14$

total verklaarde varlantie .11 .19 .22 .12 $.28 \quad .11$ 
Samenvattend:

De betekenis van de structuurgegevens voor de verklaring van verschillen in meningen over het uitoefenen van de huisartsentaak laat een duidelijk verschil zien tussen de huisartsen met een relatief brede of thet een relatief smalle takopvatting. Evenals bij de voorafgaande beschrijving van de verschillen tussen deze groepen, kan ook hier de typering van de huisarts met een bewust eigen invulling van zijn taak en werk worden doorgezet. Wanneer hij een grotere praktijk heeft kan een hoger niveau van somatische diagnostiek en therapie worden nagestreefd. Dit is mogelijk te verklaren doordat de frequentie van vórkomen van de onderscheiden aandoeningen en klachten toeneemt, en een meer uitgebreide uitrusting "Ionend" zal zijn. Ongeacht de aanwezigheid van de gezondheidszorgvoorzieningen makt hij daar een meer overwogen gebruik van. Dit type huisarts is relatief vaker aan te treffen in de meer geürbaniseerde gebleden met een jonge bevolking. Het gevoel van gebrek aan tijd en ondersteunende faciliteiten neemt af, wanneer de ervaring als huisarts toeneemt, en is minder aanwezig bij de samenwerkende huisarts dan bij de solist.

\subsection{CONCLUSIES}

De beschrijving van de groepen huisartsen die getypeerd zijn naar de breedte van hun taakopvatting, heeft noodzakelijkerwijs een sterk veronderstellend karakter. De bedoeling is om aanwijzingen te vinden voor verdergaande interpretatie van de algemene verklaringen van verschillen in functie-uitoefening en aanknopingspunten te geven voor nader onderzoek.

Het beeld dat uit deze beschrijving ontstaat, onderscheldt enerzijds huisartsen met een eigen en bewuste invuliing van hun takenpakket, anderzijds huisartsen met een meer door gemiddeld patiëntenaanbod en werkomstandigheden beheerst functioneren. Over de oorzaken voor het ontstaan van dit verschil in algemene houding ten aanzien yan het werken als huisarts, zijn in dit onderzoek geen verklaringen te vinden. 
Figuur 9: Schematisch overzicht van de meest belangrijke relaties tussen de functie-uitoefening, de taakopvatting en de achtergrondkenmerken, gesplitst naarde groep huisartsen met relatief smalle (....) en met relatief brede taakopvatting (

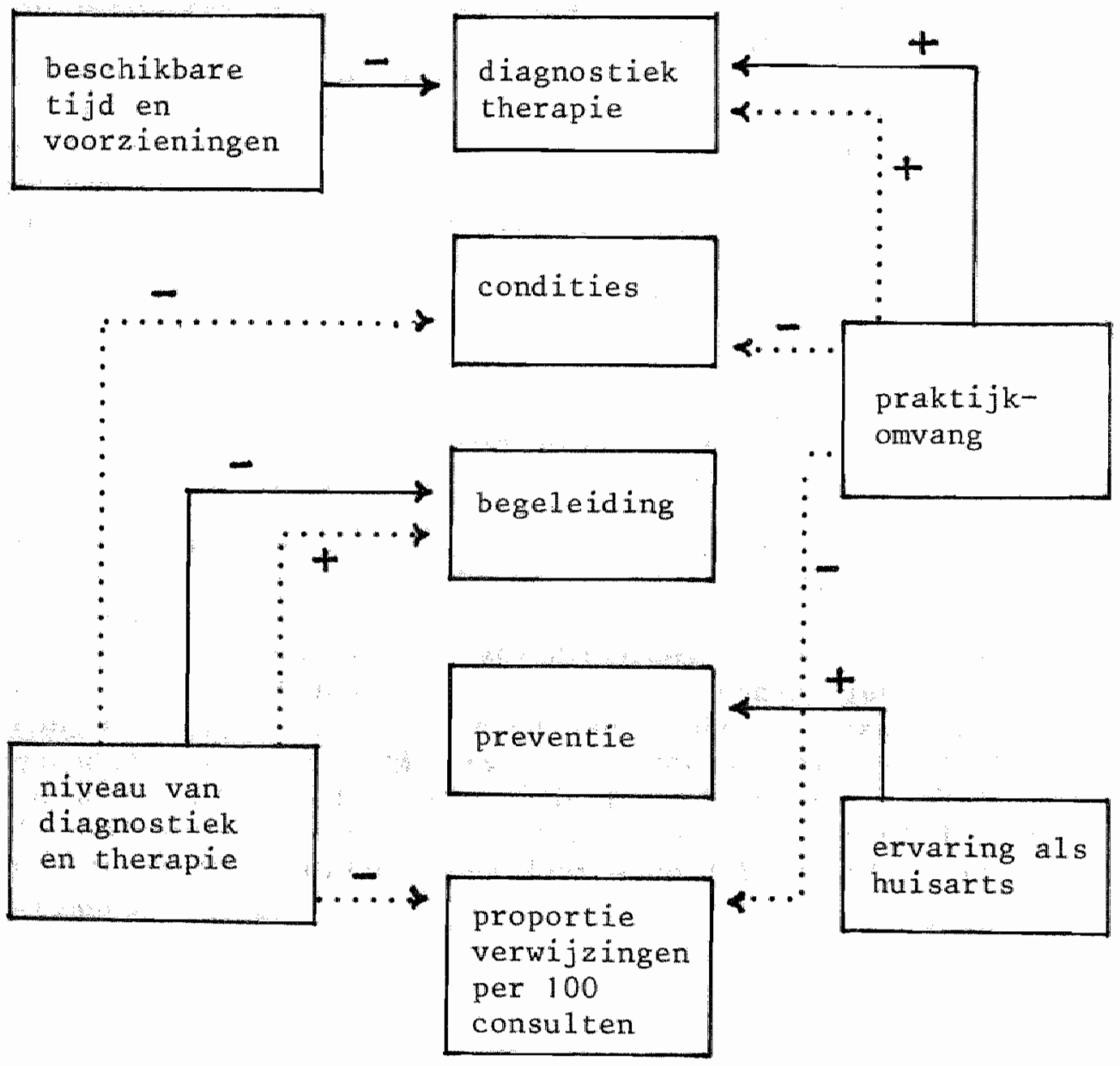


HOOFDSTUK 8

SAMENVATTING EN DISCUSSIE

8.1. SAMENVATTING VAN DE OPZET EN UITVOERING

Het onderzoek is opgezet met het doel de plaats die de huisarts inneemt in de Nederlandse gezondheidszorg empirisch te beschrijuen met behulp van de werkzaamheden die hlj verricht. Daartoe werd het werk van de huisarts ingedeeld in zes functies en vier aanwullende rubrieken, geoperationaliseerd in direct warneembare activiteiten. De indeling vond plaats aan de hand van het normatieve takenpakket van de huisarts, beschreven door commissies van artsen op verschillende momenten in de ontwikkeling van het beroep en met onderscheiden doeleinden.

De hoofdreden voor het onderzoek was het zoeken naar empirische aangrijpingspunten voor een beleid, dat gericht is op versterking van de eerste lijn van de gezondheldszorg. Wanneer veranderingen van inhoud en omvang van de werkzaamheden die de huisarts verricht, worden nagestreefd, is het van belang inzicht te hebben in de gevolgen die verwacht kunnen worden van wijzigingen in de werkomstandigheden en de taakopvatting van de huisarts. Deze bedoeling leldde ertoe om naast de registratie van het werk dat de huisarts verricht, tevens gegevens te verzamelen over zijn taakopvatting, kenmerken van zijn praktijksituatie en de gemeente waarin zijn praktijk is gevestigd. Met behulp van deze gegevens werd een verklaring gezocht voor de verschlllen tussen de afzonderlijke huisartsen in de aard en omvang van de onderscheiden functies en rubrieken in hun werk.

De registratie van de werkzaamheden werd uftgevoerd door artsen, die als observatoren in 93 praktijken gedurende ongeveer 20 uur de huisarts volgden. De observatoren waren getraind in de toepassing van het categorieënstelsel en legden alle activiteiten van de huisarts tijdens de observatiepe- 
riode vast naar frequentie van voorkomen, volgorde en tijdsduur, onderscheiden naar de werkvormen: vrij- of afspraakspreekuur, visite en overige omstandigheden. Het vastleggen van deze gegevens gebeurde met een speciaal voor dit doel ontworpen "gedragsobservatie-registrator", waardoor op eenvoudige wijze directe computerverwerking mogelijk was.

De informatie over de taakopvatting van de huisarts werd verzameld door middel van een ontworpen vragenlijst. De hierin opgenomen vragen waren gericht op de opvattingen van de huisarts over de breedte van $z i j n$ taak, het niveau warop en de omstandigheden waaronder hij als huisarts werkzaam was. Naast de groep van geobserveerde huisartsen werd een representatieve steekproef van Nederlandse huisartsen samengesteld, waraan dezelfde vragenlijst schriftelijk werd voorgelegd.

De kenmerken van de praktijk die betrekking hebben op omvang, vorm en samenstelling werden eveneens in de vragen1ijst opgenomen. Van de gemeente waarin de huisartspraktijk gevestigd was werden de door het CBS verzamelde gegevens gebruikt aangaande de samenstelling van de bevolking en de urbanisatiegraad. De gegevensverzameling in de grote steekproef van huisartsen, waarbij alleen de vragenlijst werd gebruikt, vond plaats in de maanden april en mel 1979; de observaties werden uitgevoerd gedurende de maanden maart tot en met juni van datzelfde jaar.

\subsection{SAMENVATTING VAN DE RESULTATEN}

De beschrijving van de werkzaamheden die de huisarts verricht, levert als duidelijk resultat de anduiding van de rol die de huisarts in de Nederlandse gezondheidszorg vervult als "poortwachter". Bijna een kwart van de gehele werktijd wordt besteed aan activiteiten ten behoeve van de diagnostiek. Wanneer hierbij gevoegd wordt de tijd die aan "theraple" en "condities" wordt besteed, dan is ruim de helft van de totale tijd benoemd.

De werkzaamheden in het kader van "preventie" en "begele1ding" omvatten gezamenlijk lets meer dan tien procent van de gehele werktifd, een ongeveer even groot aandeel als door de 
"reistijd" en "privétijd" afzonderlijk in beslag wordt genomen.

Van iedere 100 consulten eindigen er gemiddeld tien met een verwijzing naar een andere hulpverlener in de gezondheidszorg. Het aantal verwijzingen naar personen of instanties die niet tot de gezondheidszorg worden gerekend, bijvoorbeeld het algemeen maatschappelijk werk of de gemeentelijke sociale dienst, is bijzonder gering.

De opvattingen die de huisartsen hebben over de breedte van hun taak, het niveau waarop en de omstandigheden waaronder gewerkt moet worden, vertonen slechts een geringe interne en onderlinge samenhang. Het ontbreken van een consistent patroon in de uitgesproken meningen over het functioneren als huisarts wijst op een beroepsgroep met een nog nauwelijks uitgekristalliseerde beeldvorming.

Voor de verklaring van de verschillen in de relatieve tijdbesteding aan de onderscheiden functies en rubrieken, is gebruik gemaakt enerzijds van de taakopvattingen en anderzijds van een aantal structuurkenmerken betreffende de huisartsenpraktijk en de gemeente van vestiging. Het mechanisme dat bij deze verklaring werd verondersteld werkzaam te $z \ddot{1 j n}$, houdt in dat de taakopvatting van een huisarts, evenals het aantal jaren praktijkervaring, direct de tijdbesteding aan de onderscheiden groepen van activiteiten beinvloedt. De omgevingsfactoren bezitten een indirecte werking die verloopt, ofwel via het gemiddeld aanbod van patiënten, ofwel via veranderingen in taakopvatting.

De variantie in de relatieve tijdbesteding aan "diagnostiek", "therapie" en "condities" kan voor ruim 30\% verklaard worden, waarbij vooral het verschil in gemiddeld patiëntenaanbod van betekenis is. Een toenemend geniddeld aantal patlënten per uur blijkt voor het werk van de huisarts een stijging van de relatieve tijdbesteding van "dlagnostiek" en "therapie" in te houden en een afname van de tijd die aan "condities" wordt besteed, ongeacht de andere in het onderzoek opgenomen factoren.

Voor verschillen in de proportie"verwijzingen" blijkt eveneens het gemiddeld patiëntenaanbod van betekenis: een toenemend gemiddeld aantal patiënten per uur gaat samen met een 
naar verhouding afnemend aantal verwijzingen.

Het gemiddeld patiëntenaanbod blijkt niet van invloed op de hoeveelheid tijd die de huisarts aan "begeleiding" en "preventie" besteedt: een afnemend patiëntenaanbod betekent niet dat verhoudingsgewijs de tijdbesteding an "preventie" en "begeleiding" toeneemt.

Het aantal patiënten dat gemiddeld per uur door de huisarts wordt "gezien", verschilt per praktijk, afhankelijk van de prakt1jkomvang en het al dan niet apotheekhoudend zijn. Naarmate de praktijkomvang toeneemt wordt een groter gemiddeld aantal patiënten per uur aangetroffen; de huisarts met een apotheekhoudende praktijk haalt een lager gemiddeld aantal patiënten per uur dan zijn niet-apotheekhoudende collega.

Het aantal jaren dat de huisarts praktiseert blijkt van betekenis voor de verklaring van verschillen in de tijdbesteding aan "dlagnostiek" en "begeleiding" en in de proportie verwijzingen. Meer ervaring betekent naar verhouding meer tijd voor "begelelding" en minder voor "diagnostiek" evenals minder verwijzingen.

Het niveau waarop de huisarts zijn diagnostisch en therapeutisch werk wil verrichten, is van invloed op de tijdbesteding aan "preventie" en de proportie verwijzingen. Wordt een hoger niveau nagestreefd, dan stijgt de aandacht voor preventie en daalt het aantal verwijzingen.

De ervaren werkomstandigheden zijn eveneens van wisselende betekenis. Een grotere tijdsdruk wordt ervaren in het functioneren als huisarts wanneer relatief veel tijd aan "diagnostiek" en "theraple" wordt besteed; voor de andere activitelten bestat deze samenhang niet.

Het gebruik dat door de huisarts van de gezondheldszorgvoorzieningen wordt gemakt bij de uitvoering van zijn takenpakket speelt alleen een rol bij "diagnostiek". De huisarts die zegt deze voorzleningen in verhouding tot zijn collegae veel te benutten, blljkt relatief veel tijd aan diagnostiek te besteden.

Bij de indirecte werking die van de structuurkenmerken wordt verondersteld uit te gaan, is vooral de betekenis van de praktijkomvang aantoonbaar. Zowel door de samenhang hiervan met het gemiddeld patiëntenaanbod, als door de beinvloeding van de taakopvattingen, blijkt de grootte van de praktijk 
voor alle functies, met uitzondering van "begelelding", van betekenis: bij toenemend aantal in de praktijk ingeschreven patiënten is een naar verhouding toenemende tijdbesteding aan "dlagnostiek", "theraple" en "preventle" te verwachten, gelijktijdig met een afnemende tijdbesteding aan "condities" en dalend aantal verwijzingen per 100 consulten.

De breedte van de taakopvatting blijkt voor de verklaring van verschillen in relatieve tijdbesteding een interveniërende rol te spelen. De splitsing van de geobserveerde huisartsen in twee groepen op grond van het verschil in breedte van takopvatting, laat zien dat de huisartsen met de relatief brede taakopvatting over het geheel genomen van een wat bewustere opstelling in hun functioneren blijk geven. Deze groep is minder afhankelijk van het gemiddeld patiëntenaanbod en de omstandigheden waaronder zij hun werk moeten uitoefenen. Door deze huisartsen wordt een lager niveau van somatische diagnostiek en therapie nagestreefd, waardoor meer relatieve tijd voor "begeleiding" kan worden gevonden. Het aantal malen dat, in verhouding tot het totaal aantal consulten, wordt verwezen, staat bij huisartsen met een relatief brede taakopvatting los van het gemiddeld patiëntenaanbod. De praktijkomvang is bovendien bij huisartsen uit deze groep niet van invloed op het aantal patiënten per uur.

\subsection{BETEKENIS VAN DE ONDERZOEKRESULTATEN}

De ultkomsten uit ons onderzoek bevestigen de belangrijke functie die de huisarts uitoefent als poortwachter van de Nederlandse gezondheldszorg. Aan diagnostlek wordt, in verhouding tot alle andere werkzaamheden, de meeste tijd besteed; van de totale patientenstroom die een beroep op de huisarts doet wordt negentig procent afdoende geholpen. Ten gevolge van ziljn positie als de "eerste" hulpverlener wordt de tijdbesteding van de huisarts in sterke mate afhankelijk van het patiëntenaanbod. Hierdoor ontstaat een dienstverlening op afroep, die door zijn inhoud en wijze van verstrekking slechts in geringe mate te belnvloeden valt, (Van der Voort, 1982). De omvang van de vraag naar gezondheidszorg is, anders gezegd, in hoge mate bepalend voor de tijdbesteding van de huisarts. 
De beleidsintentie an de eerste 1 ijn te versterken, betekent feitelijk veranderingen in de hulpverlening door de huisarts. Wanneer de "Schets van de eerstelijnsgezondheidszorg" (Tweede Kamer, zitting 1979-1980, par. 2) wordt gevolgd, dan moet een inhoudelijke verschuiving worden nagestreefd van minder curatief naar meer begeleiding en preventie, naast een inperking van de doorstroom naar het tweede echelon. Verkleining van de praktijkomvang, stimuleren van samenwerkingsvormen en het uitbreiden van de bestaande ondersteunende voorzleningen, blijken volgens onze onderzoekresultaten geen inhoudelijk verschuivingen in het functioneren van de huisarts te bewerkstelligen in de gewenste richting. Het bevorderen van een bewuste, andere opstelling tegenover de inhoud en ultvoering wan de taken bij de huisarts, is weliswar een minder direct aangrijpingspunt, maar lijkt daarentegen meer succesvol.

Hier $11 \mathrm{jkt}$ eerder een overleg over het centrale beleid met het Hulsartsengenootschap van belang, dan onderhandelingen over normverlaging of structurverbetering met de Landelijke Huisartsenverenlging. Een inhoudelijke stellingname als bewuste keuze van taken (Spreeuwenberg, 1982) kan mogelijk het resultaat zifn van goed voorbereide en centraal georganiseerde naschollingscursussen.

Een verandering in het doorstromingspercentage van patiënten naar de volgende echelons, is eveneens niet te verwachten van de reeds eerder genoemde beleidsvoornemens die gericht zijn op versterking van het eerste echelon. Een redelijk drukke praktijk met een relatief hoog gemiddeld patlëntenaanbod vormen julst de omstandigheden waarbinnen een verhoudingsgewijs gering aantal doorverwijzingen plaatsvindt. Praktijkvormen waarin enigerlei gestructureerde samenwerking tussen eerstelifns-hulpverleners plaatsvindt voeren niet zonder meer nat een geringere verwifsproportie op het total aantal consulten. De duidelijk grotere bereldheid tot samenwerking die hulsartsen in deze praktijken bezitten leidt nlet tot een ander verwijsgedrag, wel tot een grotere relatleve tijdbesteding aan "condities", waarvan de "samenwerkingsactiviteiten" ongeveer een vijfde deel uitmaken. Waarschijnlijk is de meest effectieve wijze om terugdringen van het doorstromingspercentage te bevorderen, gelegen in het indamnen van het patiëntenaanbod. 
Regulering en terugdringen van de vraag naar hulsartsenhulp, trachten greep te krijgen op de invoer in het systeem, zal eerder de gewenste effecten bereiken bij de besturing van de gezondheidszorg, dan moeizame pogingen om organisatorische verschuivingen binnen het systeem te bewerkstelligen. Versterking van de eerste 1 ijn betekent begrenzingen stellen aan het loket van de gezondheidszorg. Een takenpakket van de huisarts waarin voor alle welzijnsproblemen in princlpe d1recte hulp wordt gegarandeerd vormt hiertoe geen bijdrage.

\subsection{DISCUSSIE}

Onderzoek als het hier gerapporteerde, bezit noodzakelijkerwijze kenmerken van onvolledigheid en levert minder bewijzen dan onderwerpen voor discussie. De redenen hiervoor zijn voor een belangrijk deel gelegen in het gebrek aan onderzoektraditie in Nederland op het terrein van de hulpverlening door de gezondheidszorg. Niet alleen zijn meetinstrumenten en meettechnieken tengevolge van de geringe aantallen en sterk verspreide onderzoekingen zeer uiteenlopend, ook de hypothesevorming en -toetsing kan nauwelijks plaatsvinden. Het afgelopen decennium hebben vele onderzoekers hun aandacht op de gezondheidszorg gericht, maar van een sturing en onderlinge afstemming kan nauwelijks worden gesproken.

Ook in ons onderzoek is het gemis van verankering in een stroom van direct samenhangende en verwante onderzoekingen in Nederland duidelijk warneembar. Op een groot aantal onderdelen zijn "eerste pogingen" ondernomen en werd een groter beroep op creativiteit dan op voorgaand onderzoek gedaan. De ontwikkeling en toepassing van observatiecategorleën is hiervan een voorbeeld, evenals de meting van de taakopvattingen.

Naast deze algemene beperking moeten nog enkele specifieke kenmerken van dit onderzoek worden genoemd die bij de interpretatie een rol hebben gespeeld.

Allereerst ontbreekt bij de geobserveerde gegevens de informatie over de persoon van de patiënt en de door hem gepresenteerde klachten. Dat dit aspect niet in de opzet van het 
onderzoek is betrokken kan achteraf worden betreurd. De probleemstelling makte weliswar het verzamelen van patiëntgegevens niet noodzakelljk. Maar bij de interpretatie van de resultaten, evenals ten behoeve van enige vorm van "controle" op de observaties, zou dit type gegevens zeer goed te gebruiken zijn geweest.

Vervolgens zou een beperkt aantal kwaliteitscriteria omtrent het functioneren van de huisarts de analysemogelijkheden hebben vergroot. Zonder deze blifft het analyseschema een wat formeel gehee1, met beperkte inhoudelijke diepgang. Formulering van dit type criteria was echter niet zo eenvoudig, afgezien van de bedreiging die ten tijde van het onderzoek uitgling van observerende "beoordelaars".

Tenslotte zou het dienstig geweest $z i j n$, ook ten behoeve van vervolgonderzoek, indien aan de geobserveerde hulsartsen zelf zou zijn gevraagd om aan te geven hoe naar hun mening de tijdverdeling over de verschillende activiteiten had plaatsgevonden. De betekenis die aan "eigen registratie" moet worden toegekend bij de gegevensverzameling over praktijkultoefening door huisartsen, zou hierdoor zijn verduide$11 \mathrm{jkt}$.

Het aangeven van gebieden voor vervolgonderzoek is niet zo zinvol, omdat de inbreng van dit type onderzoek in én geheel onderzoeksplan betreffende de eerste-11jnsgezondheidszorg priotitelt verdient boven in onderdelen, los van elkaar, ultgevoerde deelstudles.

Het verdient aanbeveling om te streven naar éen geintegreerd onderzoeksplan, gericht op de eerstelijns-gezondheidszorg in Nederland. Een zwartepuntbeleid in het kader van de -financiering van het wetenschappelijk onderwijs zou het ontstaan van enkele universitaire onderzoekscentra kunnen bewerkstelligen.

Tege11jkert1jd zou de derde geldstroom gebundeld moeten worden en door éen instituut, bij voorkeur het Nederlands Huisartsen Instituut, worden gecoördineerd. Een permanent overlegorgaan met vertegenwoordigers uit de betrokken instellingen, de beroepsgroepen en de overheid, zou als stuurgroep 
kunnen functioneren. Niet alleen de economische en financiële situatie makt constructies als deze noodzakelijk. Ook de obligate verzuchting van de afzonderlijke onderzoekers dat op vele punten nader onderzoek noodzakelijk is, zou een overbodige constatering worden en achterwege kunnen blijven. 
This thesis presents the results of a study concerning the functions of the general practitioner in the Dutch health care system. It relates his task-perception, the structural characteristics of his practise and its geographical location with the execution of his functions.

The origin of this study is described in chapter 1. The most important startingpoint is to be found in the policy of the Government which aims at strengthening of primary health care. The intended change in the functioning of the health care system is based on the supposed possibility of effective changes in the way the general practitioner executes his work.

The succes of such a policy is dependent upon the extent to which the general practitioner's work is influenced by the circumstances under which it is to be carried out.

The problem-statement is placed in the framework of the relevant 1iterature in chapter 2. Previous studies in the Netherlands of the functioning of general practitioners appear to have been directed either at parts of their work only, or concern specific aspects of their medical performance. Moreover, data collection has in many instances been carried out in a very limited number of practices.

Relevant studies in other countries mostly concern outputmeasurements within the context of production functions and offer little comparable results for the Dutch situation. It must be stated here that worthwhile references included in the present study pertain to parts of earlier research only.

The problem-statement is elaborated in chapter 3. A definition is given of the functions performed by the general 
practioner in the Dutch health care system. These functions are identified as: "diagnostics", "therapy", "attendance", "prevention", "referral". All these functions are described as sets of activities. Besides these functions, additional groups of activities are identified in order to cover the entire scope of the daily work. These categorles are established as "conditions", "soclal contacts", "off duty" and "travelling time". These categories are also described as sets of activities. By dividing the general practitioner"s work into these groups of activities, reference is made to the job description as issued by the Dutch professional group of general practitioners.

To establish the taskperception use is made of the following items:

- the scope of taskperformance,

- the level of diagnostics and therapy,

- the willingness to cooperate with other health care workers,

- the desired avallability of time and supporting facilities.

The statements formulated with regard to these topics are used in the questionnaire that was presented to the general practitioners.

The research design and the manner in which it was executed are described in chapter 4. Observations of 93 general practitioners were conducted by medical observers, during a period of approximately 20 hours, per practioner, spread over 4 days during a week. All the activities performed by the general practitioner during this period were recorded by means of a registration device which made it possible to ensure quick processing of all the data.

The questionnaire concerning the taskperceptions was not only presented to the 93 general practitioners investigated in the present study, but also to 614 general practitioners, who formed a representative national sample, according to characteristics relevant to this study.

The general practitioner's work and his tasks-perceptions are described in chapter 5. The relative time spent on the various functions and categories is presented, as well as the answers to the questions concerning taskperception. 
These answers are clustered according to the division encountered in the representative sample.

It is evident from the data that diagnostics occuples a relatively large part of the general practitioners work and that, in comparison, prevention and attendance are only given a limited amount of time. Of the total number of patients who consult the general practitioner, an average of $10 \%$ is referred to other workers within the health care system. Referrals outside the health care system occur extreme1y rarely. A large amount of dispersion, in which little structure is found, turns out to be present in the taskperceptions. The clustered answers show consplcious differences with regard to the extent of taskperformance. On the contrary, there is more unanimity regarding the level at which diagnostics and therapy should be administered.

An explanation for the variance in the relative time spent is given in chapter 6 . The regression analyses by means of the structural and perception variables give an explained varlance of $30 \%$ for "dlagnostics", "therapy" and "conditlons". The average patient-load, related to the size of the practice, appears to be of special importance for this explanation. This variable is not relevant for explaining the variance in relative time spent on activities for "prevention" and "attendance". In respect of these functions the practical experience of the general practitioner and the level at which he wishes to perform in diagnostics and therapy are important.

The number of referrals per 100 consultations decreases as the average number of patients per hour rises and the general practitioners experlence increases.

Supporting health care facilities are only of significance for the diagnostic activities.

Collaboration within the primary health care system and a willingness to this end, lead to more time spent on "conditlons" but has no influence on the remaining time allocation.

Chapter 7 describes the intervening effect of the opinion of the general practitioner on the extension of tasks to be performed.

A preference for tasks to be extended points at a more con- 
sidered task performance, shown by less dependence upon the average patientload and more attention for "attendance", at the expense of a high diagnostic and therapeutic level. It is also shown that general practitioners with a broader perception of their task, spend more time on prevention when their experience increases.

The significance of the results of this study is discussed in chapter 8 . It is submitted that the general practitioner depends considerably upon the average patient-load when allocating his time on the different activities. A shift in the pattern of time allocation in the direction of more attendance and more prevention can not be expected of structural measures. A more explicit attitude by the general practitioner with regard to his task will possibly be of more significance for this desired shift.

A decrease in the number of referrals to other health care workers can neither be expected of structural changes in the system, nor of stimulation towards structural collaboration within the primary health care sector.

Strengthening primary health care aiming at essential shifts in the taskperformance and decreasing the referral rate, should rather be expected from a change in the general practitioners taskperception than from structural measures. 
LITERATUUR

AALDEREN, H.J. van: Anders helpen, anders helen, Amsterdam, V.U., oratie, 1974.

AHAMAD, B, BLAUG, M.: The practice of manpower forecasting, Elsevier Scientific Publ. Comp.,

Amsterdam, London, New York, 1973.

AULBERS, B.J.M., de WAARD, F.: Praktijkanalytische gegevens uit het intermitterend morbiditeitsonderzoek, Huisarts en Wetenschap, 13, 1970, 171-177.

AULBERS, B.J.M., OLIEMANS, A.P.: Beschouwingen over het verrichtingenciffer, Huisarts en Wetenschap, 14, 1971.

BERGER, L.P., LUCKMAN, Th.: The social construction of reallty,

Pinguin University Books, Kent, 1966.

BERGSMA, J.: 't Spreekuur, naar de huisarts en terug, Subfaculteit Psychologie, Tilburg, 1979.

BLOKLAND - KUHLER, N.M.: Arbeidsstudie in een huisartspraktijk,

Huisarts en Wetenschap, 17, 1974, 256-259.

BOOM, de - DUIN van, F.T., e.a.: Nota Gezondheidscentra, Intagon, Amsterdam, 1973.

BOOTS, J.M, ZUTPHEN, van, W., : Taakopvattingen van de huisarts,

Medisch Contact, 36, 1981, 65-68. 
BOOTS, J.M.J.: Gedragsobservatie-registrator, Gezondheid en Samenleving, 1, 1980, 302-303

BOSCH, A.J.: Geneesmiddelenvoorziening: wie, wat, waar?, Medisch Contact, 37, 1982, 537-542.

BRAND-KOOLEN, M.J.M., e.a.: Tijdschrijven, ervaringen met een onderzoek naar de besteding van (werk)tijd, Intermediair, 15, 1979, 39-47.

BREMER, G.J. WESTREENEN, van, E.: De werkzaamheden in de huisartspraktijk nu en in de toekomst, Huisarts en Wetenschap, 7, 1964, 2-17

BREMER, G.J.: Het verwijzen in de huisartspraktijk, Utrecht, dissertatie, 1964.

BROCK, C., Consultation and referral patterns of family physicians,

Journal of Family Practitioners, Vol. 4, 1977 , $1129-1136$.

BROUWER, W.J.C.: Goodwill en overnameprijs van huisartsenpraktijken,

Medisch Contact, 35, 1980, 248-255.

BUMA, J.T.: Inventarisatie van een huisartsenpraktijk, Medisch Contact, 7, 1952.

BUTTER, J., Effects of manpower utilization on cost and prom ductivity of a neighbourhood health center, The Milbank Memorial Fund Quarterly, Vol. 2, no. 4, oct. 1972, 421-452.

COHEN, J.: Weighted kappa: nominal scale agreement with provision for scaled disagreement or partial credit, Psychological Bulletin, 1970.

COMMISSIE ARTSENBEHOEFTE,

Verslagen en Mededelingen betreffende de Volksgezondheid, no. 5, 1969. 
CREBOLDER, H.F.J.M.: Onderzoekingen rond een Gezondheidscentrun, cliënten, cijfers en beschouwingen, Mijmegen, dissertatie, 1977.

CROMME, P.V.M. : Toetsing als argument voor praktijkverkleining, Medisch Contact, 35, 1980, 245-247.

DEEN, K.J. van: Arbeidsanalyse in een plattelandspraktijk, Groningen, dissertatie, 1952 .

DOKTER, H.J.: Inhoude11jke argumenten voor praktijkverkleining,

Medisch Contact, 35, 1980, 235-239.

DOKTER, H.J. e.a.: Gezondheld en Gezondheidscentra, De Erven Bohn b.v., Amsterdam, 1974.

DONAIDSON, M.C., e.a.: Time study of doctors and nurses at two Swedish Health care centers, Medical Care, Vol. IX, no. 6, 1971, 457-467.

DOPHEIDE, J.P.: Verwijzingen door de huisarts, Gezondheld en Samenleving, 3, 1982, 141-151.

DUUREN, R., van, HUPKENS, L.A.J.: Verschillen in verwijsgedrag door samenwerkingsverband, Medisch Contact, 36, 1981, 1933-1936.

EISENBURG, J.M.: Use of diagnostic services by physicians in community practice,

Medica1 Care, Vo1 XIX, no. 3, 1981, 297-309.

ES, J.C., van, PYLMAN, H.R.: Het verwijzen van ziekenfondspatiënten in 122 Nederlandse Huisartsenpraktijken,

Huisarts en Wetenschap, 13, 1970, 433-439.

ES, J.C., van: Paradigma's van de huisartsgeneeskunde, Hulsarts en Wetenschap, $21,1978,451-458$.

EVERITT, B,: Cluster analysis, Halsted Press, New York, 1974. 
FELDSTEIN, M.S.: Econometric studies of health economics, in: Frontiers of quantitative economics, Vol. II, e.d. by M.D. Intrilligator and D.A. Kendrick, North-Holland Pub1. Comp., Amsterdam, 1974.

FESTEN, H.: 125 jaar geneeskunst en maatschappij, K.N.M.G., Utrecht, 1974.

FOETS, M., NUYENS, Y.: Focus op de belgische gezondheldszorg,

Brussel, 1978.

FUCHS, V.R.: Problems and choices, in:

D. Mechanic (Ed.): Readings in Medical sociology, The Free Press, New York, 1980.

GEUS, C.A., de: Congresrede 1978, Huisarts en Wetenschap, $21,1978,483-485$.

GREEP, J.M.: Naar een medische overbevolking, Medisch Contact, 35, 1980, 481-489.

HARRIS, D.M.: An elaboration of the relationship between general hospital bedsupply and general hospital utilization, Journal of Health and Soctal Behavior, 16, 1975, 163-172.

HIESTAND, D.J.: Research into manpower for health services, Milbank Memorial Fund Quarterly, 1966, 146-186.

HILDEBRAND, D.K.: Prediction analysis of cross classification,

Wiley and Sons, New York, 1977.

HIRS, W.M., HOSMAN, C.M.H.: Psychische problematiek en de centrale positie van de huisarts,

Maandblad voor Geestelijke Volksgezondheid, 1973, 49-56. 
HOGERZEIL, H.H.W.: Resultaten in een huisartsenpraktijk, Utrecht, 1954.

HOGERZEIL, H.H.W.: Kritische beschouwingen betreffende het rapport van $\mathrm{dr}$. I. van der Wielen, Huisarts en Wetenschap, 3, 1960.

HOLMES, C.: Toward the measurement of primary care, Milbank Memorial Fund Quarterly, Vol. 56, 1978, 231-251.

HOOF, J.J.B.M., van: Het beroep als object van soclologisch onderzoek, SISWO, Amsterdam, 1969.

HORST, F. van der, VIERHOUT, W., MEULDERS, W.: Probleemgeoriënteerde verslaglegging,

Huisarts en Wetenschap, 24, 1981, 325-335.

HOVE-BAECK, A, van: Het professionaliseringsproces van de Nederlandse huisarts, I, II,

Leuven, dissertatie, 1978.

HUYGEN,F.J.: Gezondheid, ziekte, gezin en huisarts, Medisch Contact, 35, 1980, 433-435.

HUYSMANS, F., e.a.: Gezondheldszorg in Nederland, SUN, Nijmegen 1973.

JACOBY, I., KNIDIG, D.: Taskanalysis in national health service corps field stations: a methodological evaluation, Medical Care, Vol. XIII, 1975, 308-317.

JANSEN-EMMER, E.M.: Bijdrage tot de kennis van het aandeel van de hulsarts in de Geneeskundige verzorging van de Amsterdamse bevolking, Zeist, dissertatie; 1958. 
JEFFERS, J.R.: On the demand versus need for medical services and the concept of "Shortage", American Journal of Public Health, Vol. 61, 1971, 46-63.

JOHNSON, T.J., Professions and power,

The Macmillan Press, London, 1972.

JUFFERMANS, P.: Overheidsbeleid en ziekenfondsen 1945-1977, Sun, Nijmegen, 1977.

KERLINGER, F.N.: Foundations of behavioral research, Holt, Rinekart and Winston, London, 1964.

KERLINGER, F.N., PEDHAZUR, E.J.: Multiple regression in behavioral research, Holt, Rinekart and Winston, London, 1973.

KIMBELL, L.J., LORANT, J.M.: Physician productivity and returns to scale, Health Services Research, no. 4, 1977, 367-379.

KLINKERT, J.J.: Verloskundigen en artsen,

Alphen aan de Rijn/Brussel, dissertatie, 1980.

KLINKERT, J.J.: Huisarts en professie,

Huisarts en Wetenschap, 21, 1978, 6-10, 43-47, 93-96.

K.N.M.G.-comissie: De plaats van de medicus in het eerste echelon,

Medisch Contact, 31, 1976, 141-164.

KOVNER, J.W.: Measurement of outpatient office visit services,

Health Services Research, no. 3, 1969, 112-127.

KROGT, Th.P.W.M., van der,: Professionalisering en collectleve macht,

's Gravenhage, dissertatie, 1981. 
KRUIDENIER, H.J.: Afstand tot ziekenhuls van invloed op verwijspatroon, Inleg, $1977,32-39$.

KRUIDENIER, H.J.: Een onderzoek naar de factoren die de hoogte van het verwijspercentage beInvloeden, Cursus Ziekenfonds- en ziektekostenverzekeringsbeleid, 1975-1976 (scriptie).

LAMBERTS, H.: Primary Health Care monitoring project, Huisarts en Wetenschap, 23, 1980, 293-304.

LAMBERTS, M.: De morbiditeltsanalyse 1972 voor de groepspraktijk Ommoord: een nieuwe ordening van ziekteen probleemgedrag voor de hulsartsgeneeskunde, Huisarts en Wetenschap, 17, 1974, 7-42, 61-75; $18,1975,454-474$.

LAMBERTS, M.: Een toekomstvisie uit 1964: de werkzaamheden in de huisartsprakijk nu en in de toekomst, Huisarts en Wetenschap, 25, 1982, 199-202.

LAMBERTS, H.: Hoe beInvloedbaar is de huisarts?, Huisarts en Wetenschap, 24, 1981, 424-430.

LAMBERTS, H.: Een nleuwe classificatie, Huisarts en Wetenschap, 22, 1979, 379-385.

LAMBERTS, H., SLOOT, E.: Multidisciplinaire problemenclassiffcatle, Hulsarts en Wetenschap, 1978, 53-62.

L.H.V.: Blauwdruk Beleid Landelijke Huisartsenvereniging, 1975.

L.H.V.: Functie-omschrijving van de huisarts, Medisch Contact, 36, 1981, 1474-1476.

L.H.V.: Regionale bijeenkomsten over blauwdruk beleid Lande11 jke Huisartsen Vereniging, Medisch Contact, 30, 1975, 1139-1143. 
L.H.V.: Nieuwe Blauwdruk,

Medisch Contact, $32,1977,973-977$.

L.H.V.: Interimrapport van de commissie takenpakket, oktober 1976.

L.H.V.: De taken van de huisarts, rapport van de Commissie Takenpakket der Landelijke Huisartsen Vereniging, Medisch Contact, 32, 1977, 765-789.

L.H.V.: Conceptrapport basistaken-pakket van de hulsarts, Utrecht, Ledenbrief $1,1982$.

LUHMAN, R.: Occupations and ideologies: a conceptual orientation,

The Kansas Journal of Soclology, VII, 63-69.

LULOFS, J.G.: Een markttheoretische benadering van professies,

Mens en Maatschappij, 56, 1981, 349-377.

MARSH, G., KAIN-CANDEL, P.: Teamcare in general practice, Croom Helm, London, 1976.

MARSH, G., Mc NAY, R.A.: Teamworkload in an English general practice; I, II,

British Medical Journal, 23, 1974, 487-493.

MELKER, R.A. de: Ziekenhuispatiënt, huisarts, huisgezin, Nijmegen, dissertatie, 1973.

MELKER, R.A. de: Gebruik diagnostische facilitelten door de huisarts, Medisch Contact, 35, 1980, 699-705.

MELKER, R.A. de: Over de invloed van de hulsarts op het verwijspercentage,

Medisch Contact, 30, 1975, 1145-1146. 
MINISTERIE VAN BINMENLANDSE ZAKEN: Indeling van Nederland in provincies nieuve stij1, februar1 1977.

MTNISTERIE VAN VOLKSGEZONDHEID en MILIEUHYGIENE:

Structuurnota Gezondheldszorg, Staatsuitgeverij, 's Gravenhage, 1974.

MINISTERIE VAN VOLKSGEZONDHEID EN MILIEUHYGIENE: De ondersteuning van de eerstelijnsgezondheidszorg, Staatsuitgeverij, 's Gravenhage, 1979.

MONTFORT, P., van: Functieclassificatie van algemene ziekenhuizen in het kader van het Basisonderzoek kostenstructuur ziekenhuizen, N.Z.I., Utrecht, 1976 .

NAVARRO, V.: Redifining the health problem and implications for planning personal health services, HSMHA Health Reports, Vol. 86, 1971, 711-724.

NELSON, E.: A Study of the validity of the task inventary method of job analysis, Medical Care, Vol. XIII, 1975, 104-113.

N.H.G.-commissie Wetenschappelijk Onderzoek: Woutschotenrapport, januari 1959.

N.H.G.: Methodısch werken, Huisarts en Wetenschap, 21, 1978, 322-335.

N.H.G.: Hoe helpt de dokter? Utrecht, 1975.

N.H.I. : Registratle wetenschappelijk onderzoek, Utrecht, 9, 1980.

NIE, H.N., e.a.: Statistical package for the social sciences, Mc Graw-H111, New York, 1975. 
OLIEMANS, A.P., VEN, W., van de: Morbiditeltsanalyse in een solo-huisartspraktijk, Huisarts en Wetenschap, 18, 1975, 437-448.

OLIEMANS, A.P.: Morbiditeit in de huisartsenpraktijk, Utrecht, dissertatie, 1969.

OSTERSON, S., SINGHAM, L.A;: The machine methaphor in medicine, in:

Mishler, E.G. (red.): Social contents of health 111 ness and patient care,

Cambridge University Press, London, 1981.

PARRISH, M.H.: Time study of general practitioners office hours,

Arch. Environ. Health, VOL. 14, 1967, 892-898.

PARRY, N., PARRY, J.: The rise of the medical profession, a study of collective social mobility, Croom Helm, London, 1976.

PEL, J.Z.S.: Over de invloed van de huisarts op het verwijspercentage,

Medisch Contact, 30, 1975, 988-990.

PETERS, J.M.: Samenwerking eerste- en tweedelijns-gezondheidszorg,

Utrecht, dissertatie, 1982 .

PHILIPSEN, H., Omvang van de gezondheidszorg onder invloed van maatschappelijke ontwikkelingen, Tijdschrift voor Sociale Geneeskunde, 54, 1976, 26-35.

PRAAG, B.M.S., van: Meer huisartsen, minder kosten, Medisch Contact, $35,1980,240-241$.

PRAAG, B.M.S., van, GAAG, J., van der, RUTTEN, F.F.H.: Vraagaanbod relaties in de sector gezondheidszorg,

Economisch Instituut, Leiden, 1975. 
POOL, J.: Instroombeperking schljnoplossing?, Medisch Contact, 36, 1981, 501-504.

POORTER, J.: Vraag en aanbod van artsen in het jaar 2009, Medisch Contact, 32, 1977, 269-273.

POSTHUMA, B., ZEE, J., van der: Tussen eerste en tweede echelon; 1.2.,

N.H.I., Utrecht, 1977-1978.

POSTHUMA, B., ZEE, J., van der: Verwijscljfers en de verkleining van de huisartspraktijk,

Gezondheld en samenleving, $1,1980,59-68$.

PUYLAERT, F.W.J.: Versterking van de eerste lijn door raadplegen van de diagnost; I, II,

Medisch contact, 33, 1978.

RAUPP, J.L.M.: Over werkwijzen van huisartsen,

Helmond, dissertatie, 1972.

REINHARDT, W.E.: Manpower substitution and productivity in medical practice; review of research,

Heal th Services Research, no. 3, 1973, 200-226.

REINHARDT, W.E.: A Production function for physicians' services,

Review of Economics and Statistics, Vol. 54, 1972,

$55-56$

RICHARDSON, J.: The Inducement hypothesis - that doctors generate demand for their own services, in:

J. v.d. Gaag and M. Perlman (eds.): Health, Economics and Health Economics,

North Holland Publishing Company, Amsterdam, 1981.

RIDDERIKHOFF, J.: Functiebepaling van de huisarts, Medisch Contact, 36, 1981, 1134-1140; 1176-1179. 
RIEDEL, R.L., RIEDEL, D.C.: Practice and performance: an assesment of ambulatory care, An Arbor, Michigan, 1979.

ROP, H.J., LAMBERTS, H., WEEL, C., van: Huisarts en verwijsgedrag,

Huisarts en Wetenschap, 22, 1979, 306-312.

RUHE, A.H.M.: Een huisartsenpraktijk in 1938 en 1954, Assen, dissertatie, 1957.

RUTTEN, F.F.H.,: The use of health care facilities in the Netherlands, an econometric analysis,

Leiden, dissertatie, 1978.

RUTTEN, F.F.H., GAAG, J. van der, PRAAG, B.M.S., van: Het ziekenhuis in de gezondheidszorg,

Economisch Instituut, Leiden, 1975.

RUTTEN, F.F.M., GAAG, J., van der : Referrals and the demand for specialist care in the Netherlands, Health Services Research, 1977, 233-250.

SMITH, B.A.: Value for money in health services, Heineman, Londom, 1976.

SPREEUWENBERG, G.: Wat betekent voor de huisarts integrale zorg?

Huisarts en Wetenschap, $25,1982,88=102$.

TEN CATE, R.S. (red.): Samenwerken samen bouwen in de eerstelijnsgezondheidszorg,

Bohn, Scheltema en Holkema, Utrecht, 1977.

THUNG, P.J., de GRUIL- EGMOND, M., van: De vraag naar artsen, tien jaar terug en nu,

Medisch Contact, 33, 1978, 985-987.

TIELENS, V.C.: De huisarts als vraagverhelderaar, in:

J.P. Dopheide, J. van der Zee (red.): Hollend naar de horizon,

N.H.I., Utrecht, 1979. 
VEDER-SMIT, E.: Schets van de eerstelijnsgezondheidszorg, Tweede Kamer, zltting 1979-1980, 16066 nrs. 1-2.

VERHOEFF, E.: Gebruik van gezondheidszorgvoorzieningen in Nederland, Nijmegen, dissertatie, 1979.

VLIET, R.C.J.A., van, VEN, W.P.M.M., van der: Analyse van medische consumptie en van verschillen tussen zlekenfonds en particulier verzekerden, CoEPS-rapport, Leiden, 1982.

VRIES, M., de: Over de Invloed van de huisarts op het verwijspercentage, Medisch Contact, 30, 1975, 1438-1440.

VRIES, - ROBBE, P.F., de: Medische besluttvorming, een aanzet tot formele geneeskunde, Groningen, 1978.

VOORT, H., van der: De "macht" van de huisarts, Huisarts en Wetenschap, 25, 1982, 135-138.

WALI, G. van der: Praktijkverkleining, matschappelijk vraagstuk, Medisch Contact, 35, 1980, 256-261.

WHITE, K.L.: Patterns of medical practice, in:

D. Clark, B. MacMahon (eds.): Textbook of preventive medicine, Boston, 1967.

WIELEN, Y., van der: De huisarts en de doeltreffendheid van zijn aandeel in de gezondheldszorg, Assen, dissertatie, 1960.

WISHART, D.: CLUSTAN user manual; third edition, Edinburg University, 1978.

WOLFE, S.: The work of a group of doctors in Saskatchwan, M1lbank Memorial Fund Quarter1y, 1967, 103-129. 
WOLFF, L., de: De opkomst van het artsenkartel, in: Haagse Post, 1978.

ZEE, J. van der: De vraag naar diensten van de huisarts, Maastricht, dissertatie; 1982 .

ZUTPHEN, W., van: Taakanalyse van de huisarts (onder voorbehoud), proefschrift in voorbereiding, Maastricht, 1983. 
BIJLAGE 1: VRAGENLIJST, GEBRUIKT BIJ "KLEINE" EN "GROTE" STEEKPROEF

gemiddeld aantal of percentage in:

Persoons- en praktijkgegevens van de huisarts

kleine grote steek- steekproef proef

Hoe lang werkzaam in huidige praktijk

$$
11.1^{\text {jaren }} 10.5
$$

Grootte van praktijk per

1 januari 1979:

- aantal ziekenfondspatiënten

2041

2000

- aantal particuliere patiënten

906

890

Apotheekhoudend?

1. nee
2. ja

67.7

71.5

32.3

28.5

Praktijkvorm:

1. solopraktijk

2. associatie

3. groepspraktijk

62.4

67.1

19.4

19.1

4. gezondhelds-

8.6

5.4 centrum

8.6

5.4

5. andere

1.1

3.0 gestructureerde samenwerking $\mathrm{nl}$.: 
Indien er sprake is wan gestructureerde samenwerking:

7a. Met wie?

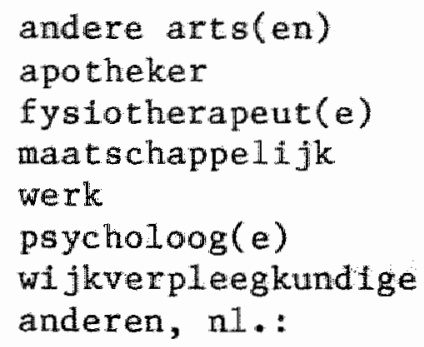

Heeft $u$ een vaste dienstregeling met uw (buurt) collegae?

$\begin{array}{llr}\text { 1. nee, door naar 9. } & 1.1 & 1.3 \\ \text { 2. ja, door naar 8a. } & 98.9 & 98.0 \\ & & \\ \text { avond/nachtdienst } & 83 & 78.8 \\ \text { vakant1e } & 82 & 82.7 \\ \begin{array}{l}\text { weekenddienst, } \\ \text { door naar } 8 \mathrm{~b}\end{array} & 95 & 96.6\end{array}$

8a. Welke?

$$
\begin{aligned}
& \text { avond/nachtdienst } \\
& \text { vakantle } \\
& \text { weekenddienst, } \\
& \text { door naar } 8 \mathrm{~b}
\end{aligned}
$$$$
96.6
$$

Indien er een weekenddienstregeling is:
8b. - Hoe vaak? 1 x per weken
- aantal patiënten

9. Heeft $u$ hulppersoneel in uw praktijk?

1. nee door naar 10. ja: $\quad 98.9 \quad 94.1$

2. ja, door naar $9 a$. 
9a. Welke hulp?

$\begin{array}{lrr}\begin{array}{l}\text { echtgenoot(e) } \\ \text { dokters- of prak- }\end{array} & 49.5 & 51.5 \\ \begin{array}{l}\text { tijkassistent(e) } \\ \text { apothekersas- }\end{array} & 80.6 & 68.6 \\ \begin{array}{l}\text { sistent(e) } \\ \text { verpleger(ster) }\end{array} & 22.6 & 16.9 \\ \begin{array}{l}\text { medisch analist(e) } \\ \text { of laborant(e) }\end{array} & 4.3 & 2.1 \\ \begin{array}{l}\text { administratieve } \\ \text { assistentie }\end{array} & 2.2 & 0.7 \\ \begin{array}{l}\text { assistent-arts } \\ \text { andere, nl.: }\end{array} & 11.8 & 9.0 \\ & 14.0 & 8.6 \\ & 6.5 & 3.9\end{array}$

10. Heeft $\mathrm{u}$ momenteel iemand in opleiding in uw praktijk

$$
\begin{aligned}
& \text { 1. nee, door naar } 11 . \\
& \text { 2. ja, door naar } 10 \mathrm{a} \text {. }
\end{aligned}
$$

10a. Wie?

$$
\begin{aligned}
& \text { co-assistent(e) } \\
& \text { arts-assistent(e) } \\
& \text { doktersassistent(e) } \\
& \text { overige, nl.: }
\end{aligned}
$$

$\begin{array}{rr}7.5 & 5.4 \\ 18.3 & 13.2 \\ 12.9 & 13.0\end{array}$

11. Wilt $\mathrm{u}$ door aankruisen aangeven over welke van onderstaande instrumenten $u$ de beschikking heeft tijdens uw praktijkuitoefening? ja:

$\begin{array}{llr}\text { 1. audiometer } & 18.3 & 23.3 \\ \text { 2. bloeddrukmeter } & 100 & 99.7 \\ \text { 3. brillendoos } & 21.5 & 23.0 \\ \text { 4. catheters } & 94.6 & 93.6 \\ \text { 5. elektrocardiograaf } & 30.1 & 20.8 \\ \text { 6. elektronische } & & \\ \text { stethoscoop } & 4.3 & 6.8 \\ \text { 7. Hb meter vg1. Sicca } & 73.1 & 71.8 \\ \text { 8. hechtset } & 97.8 & 95.3 \\ \text { 9. hyfrecator } & 65.6 & 58.0\end{array}$


10. kogeltang voor het plaatsen van een

I.U.D.

11. Mayo intubatieset

12. ophtalmoscoop

13. peak-flow meter

14. polarimeter

15. proctoscoop

16. rectoscoop

$(25-30 \mathrm{~cm})$

17. spiegel voor

indirecte

laryngoscopie

18. tonometer

19. U.K.G.-apparaat

20. Vaginaalspecula
48.4

43.6

36.6

33.2

90.3

87.9

33.3

27.9

3.2

4.2

54.8

54.1

8.6

5.0

58.1

61.6

25.8

21.0

3.2

1.3

100

99.5

\section{Taakperceptie}

Hierna volgen een aantal pagina's met uitspraken over een aantal werkzaamheden van de huisarts.

Deze uitspraken zijn geformuleerd als: "De huisarts moet..." etc. Wilt u naar aanleiding van deze uitspraken telkens aangeven wat de Nederlandse huisarts met een volledige dagtaak naar uw mening behoort te doen en wat nlet. U wordt verzocht niet uw huldige feitelijke werkzaamheden aan te geven.

Naast uw mening over wat de hulsarts behoort te doen, vragen wif ook naar uw mening over de mogelijkheden, wat betreft gezondheidszorgvoorzieningen en tijd, die u ter beschikking stam om de door $u$ gewenste werkzaameden te verrichten. Hierover hebben we per onderwerp telkens twee uitspraken geformuleerd. 
$\mathrm{Na}$ elke uitspraak staat een schaalverdeling van 1 tot 5 .

De cijfers hebben de volgende betekenis:

$1=$ mee eens

2 = enigszins mee eens

3 = neutraal of geen mening

4 = enigszins mee oneens

$5=$ mee oneens

Wilt u telkens door omcirkeling van én ciffer aangeven in hoeverre $u$ het eens of oneens bent met de betreffende uitspraak.

N.B.: Het gaat voornamelijk om uw eerste indruk van een uitspraak. Het is dan ook van belang dat u niet te lang bij een bepaalde uitspraak blijft stilstaan.

"kleine" "grote"
steek- steek-
proef proef
(percentage
"mee eens")

12. Diagnostiek

1. Het analyseren van sociale pro79.3 80.8 blemen van zijn patiënten behoort tot de taak van de huisarts.

2. De huisarts moet trachten van alle $41 \cdot 3$ 50.2 klachten die zijn patiënten hem voorleggen, zelf de oorzaken te achterhalen.

3. De huisarts moet in zijn diagnose 92.4 94.4 niet alleen anamnetische onderzoekgegevens betrekken, maar tevens het gedrag van de patiënt en $z i j n$ eigen reactie daarop.

4. De huisarts moet zijn patiënten 72.8 70.1 duidelijk maken, dat hij zich in hoofdzaak met hun lichamelijk welbevinden bezighoudt. 
5. De voornaamste taak van de huisarts

51.1

is vast te stellen door wie zijn patiënt op de meest adequate wijze kan worden behandeld.

6. De huisarts dient meer aandacht te 34.8 33.7 besteden aan diagnostlek dan aan enige andere taak.

7. Ik vind de voorzieningen in mijn 91.3 87.7 omgeving ter ondersteuning van de door mij gewenste diagnostiek voldoende.

8. Naar mijn mening kan mijn diagnostiek door tijdgebrek vaak niet zo uitgebreid zijn als ik wel zou wi1len.

\section{Therapie}

1. De huisarts moet proberen zijn patiënten zo veel mogelijk zelf te behandelen in plaats van doorverwijzen.

2. Gesprekstherapie moet tegenwoordig de noodzakelijke vaardigheden van de hulsarts behoren.

3. De huisarts moet in zijn therapeutische handelen zoveel mogelijk voorop stellen dat de patiënt zelf verantwoordelijk is voor het herstel van zijn gezondheld.

4. De huisarts is de eerst aangewezene 
5. Wanneer de patiënt een behandeling

$12.2 \quad 14.4$ vraagt die de huisarts niet zinvol acht, moet hij deze toch verstrekken.

6. Bij minder dan tien bevallingen per $77.2 \quad 16.1$ jaar is het onverantwoord dat de huisarts zelf bevallingen leidt.

7. De huisarts dient meer kennis te $25.0 \quad 53.5$ van de psychofarmaca dan van psychotherapie.

8. Ik vind dat de aanwezige gezondheids62.0 73.8 zorgvoorzieningen mij voldoende in staat stellen mijn patiënten de door mij gewenste behandeling te geven.

9. Naar mijn mening kom ik door tijd$42.9 \quad 41.3$ gebrek vaak niet toe aan door mij gewenste vormen van behandeling.

14. Begeleiding

1. De huisarts moet beschouwd worden $80.6 \quad 78.6$ als de meest aangewezen persoon om stervensbegeletding te bieden.

2. De begeleiding van high-risk groe$77.4 \quad 76.0$ pen moet een van de meest belangrijke taken van de hulsarts zijn.

3. De huisarts moet psychiatrische patiënten na hun ontslag uit een inrichting zelf begeleiden.

4. De huisarts dient de begeleiding bij revalidatie van zijn patiënten in vrijwel alle gevallen zelf uit te voeren. 
5. Chronisch zieken dienen in overleg

94.6

92.0

met de specialist zoveel mogelijk

door de huisarts behandeld te worden.

6. De huisarts is meer geschikt om de

65.6

59.9

begelelding van licht psychiatrische

patiënten op zich te nemen dan de

ambulante geestelijke gezondheidszorg.

7. Ik vind dat $i k$ over voldoende speci-

fieke voozieningen kan beschikken om mijn chronisch zieken een gepaste begeleiding te geven.

8. Naar mijn mening heb ik voldoende tijd 58.1 67.2 om chronisch zleken uit mijn praktijk de door mij noodzakelijk geachte begeleiding te geven.

\section{Preventie}

1. De individuele primaire preventie moet tot het specifieke terrein van de huisarts worden gerekend.

2. In iedere huisartsenpraktijk zou door de huisarts periodiek screeningsonderzoek moeten worden verricht bij high-risk groepen.

3. De huisarts behoort zijn patiënten

op te voeden tot een selectiever gebruik van de medische voorzleningen.

4. De huisarts moet zich vanuit zijn werk 38.0 ook met sociale en politieke problemen bemoeien. 
5. De maatschappelijke gezondheidszorg

moet het merendeel van de primaire preventietaken van de hulsarts overnemen.

6. Vroege opsporing behoort meer tot de

taken van de maatschappelijke gezondheidszorg dan tot de taken van de huisarts.

7. Het signaleren van matschappelijke 65.2 58.2 problemen als mogelijke pathogene factoren moet bij uitstek tot de taak van de huisarts gerekend worden.

8. Ik vind dat er in mijn ongeving vol$48.9 \quad 51.8$ doende faciliteiten zijn om de door mij gewenste preventie mogelijk te maken.

9. Naar mijn mening heb ik voldoende 42.4 42.6 tijd om de door mij gewenste vormen van preventie toe te passen.

16. Verwijzing binnen de gezondheidszorg

1. Huisartsen moeten gericht naar super79.1 86.0 specialisten kunnen verwijzen.

2. Huisartsen zouden door specialisten 80.4 81.9 veel intensiever bij de behandeling van door hen verwezen patiënten betrokken moeten worden.

3. In de overwegingen over al dan niet 77.2 71.2 verwijzen van een patiënt dient de huisarts ook de stijgende kosten van de gezondheidszorg te betrekken. 
4. De hulsarts behoort na een therapeu-

tische verwijzing verantwoordelijkheid voor zijn patiënt te blijven dragen.

5. Als de patiënt zelf graag verwezen will $69.2 \quad 66.6$ worden ter extra geruststelling dilent een huisarts hiermee in te stemmen.

6. Ik vind dat ik over voldoende 60.9 68.2 mogelijkheden tot verwijzen beschik.

7. Naar mijn mening moet $1 k$ door tijd25.0 22.3 gebrek vaker verwijzen dan ik eigenlijk zou willen.

17. Verwijzing buiten de gezondheidszorg

1. Huisartsen behoren patiënten indien 64.1 61.3 nodig zo snel mogelljk door te sturen nat de sociale dienstverlening.

2. De huisarts moet de sociale problemen 26.1 27.6 van zijn patiënten zelf aanpakken.

3. Wanneer de huisarts een patiënt door6.5 14.4 stuurt naar de sociale dienstverlening is zijn verdere begeleiding niet meer noodzakelijk.

4. Doordat de huisarts vaak als een soort ombudsman beschouwd wordt in30.4 27.4 zake soclale problemen, komt hij aan zijn elgenlijke werk te weinlg toe.

5. Het behoort tot de taak van de huisarts om verantwoord advies over so$50.0 \quad 50.2$ ciale voorzientngen te geven aan zijn patienten. 
6. Ik vind dat er voldoende voorzieningen 60.9

op het gebied van de sociale dienstverlening zijn, waar ik mijn patiënten, indien nodig, naar kan doorsturen.

7. Naar mijn mening kom ik ten gevolge $27.2 \quad 24.5$ van tijdgebrek onvoldoende toe aan het geven van adviezen inzake sociale problemen.

18. Samenwerking met andere eerstelijnswerkers

1. Groepspraktijken en andere vormen van $37.6 \quad 36.4$ gestructureerd samenwerken tussen huisartsen betekenen een verlichting van ieders afzonderlijke taak.

2. Het klachtenaanbod van de patiënten 90.1 86.6 makt samenwerking van de huisarts met andere disciplines onontkoombaar.

3. De oorzaken van eventuele moeilijk70.3 65.0 heden bij samenwerking met andere disicplines moeten meer gezocht worden in mentaliteitsverschillen dan in praktisch-organisatorische omstandigheden.

4. Gestructureerd samenwerken met colle$69.7 \quad 59.4$ gae-huisartsen moet beschouwd worden als een noodzakelijke voorwaarde voor een kwalitatief verantwoorde zorg.

5. Binnen een samenwerkingsvorm waaraan $57.1 \quad 59.4$ ook andere disciplines deelnemen, blijft de huisarts de uiteindelijke verantwoordelijkheid dragen voor de medische beslissingen ten aanzien van zijn patiënten. 
6. In een samenwerkingsverband met

andere disciplines komt de specifieke

taak van de hulsarts beter tot zijn recht.

7. Verschillen in werktempo en werkme-

8. Kenmerkend voor een goede samen-

werking met andere disciplines is

het gezamenliljk dragen van de verantwoordelijkheid voor de welzijnszorg voor de patiënten.

\section{Taak-ondersteuning}

Wilt $u$ door telkens een cijfer te omcirkelen aangeven in welke mate $u$ van onderstaande gezondheids- en welzijnszorgvoorzleningen gebruik makt bij het vervullen van de vermelde taken. Wilt u daarna, eveneens door omcirkeling van een cijfer, aangeven in hoeverre de genoemde voorzleningen naar uw mening van nut zijn of kunnen zijn bij het vervullen van diverse taken.

GEBRUIK

Percentage "Geen"

KS

21.5 GS

KS GS

1. röntgenfac 11 iteiten voor

2. afdeling van het centraal laboratorium van de bloedmammografie transfusiedienst

A. t.a.v. diagnostlek $\begin{array}{llll}51.6 & 58.8 & 37.6 & 30.5\end{array}$ (mogelijk) NUT

Percentage "Geen" 
3. consultatiebureau voor T.B.C.-bestrijding

4. ambulante geestelijke gezondheidszorg

5. ziekenhuislaboratorium

6. huisartsenlaboratorium

7. algemeen matschappelijk werk

8. E.C.G. dienst

Overige:
$34.4 \quad 33.3 \quad 8.6 \quad 14.1$

$\begin{array}{lllll}26.9 & 26.1 & 15.1 & 15.0\end{array}$

$29.0 \quad 35.5 \quad 21.5 \quad 17.9$

$\begin{array}{llll}33.8 & 30.6 & 30.1 & 11.6\end{array}$

$26.9 \quad 25.4 \quad 14.0 \quad 14.5$

$\begin{array}{llll}64.5 & 71.5 & 20.4 & 20.9\end{array}$
GEBRUIK (mogelijk) NUT

Percentage Percentage "Geen" "Geen"

KS GS KS GS

$31.2 \quad 24.6 \quad 17.2 \quad 14.6$

$\begin{array}{llll}94.6 & 92.8 & 65.6 & 51.7\end{array}$

$95.7 \quad 94.1 \quad 54.8 \quad 43.6$

$\begin{array}{llll}45.2 & 40.3 & 24.7 & 14.2\end{array}$

4. (geformaliseerd) overleg met gevestigd apotheker

Overige: 


\section{GEBRUIK (mogelijk) NUT \\ Percentage Percentage \\ "Geen" "Geen"}

C. t.a.v. therapeutische handelingen

KS GS KS GS

1. E.H.B.O. poli

$\begin{array}{llll}37.6 & 31.1 & 24.7 & 14.2\end{array}$

2. Eysiotherapeut

$\begin{array}{llll}5.4 & 2.0 & 7.5 & 3.2\end{array}$

3. revalidatiearts

$\begin{array}{llll}61.3 & 63.1 & 25.8 & 15.9\end{array}$

4. wijkverpleging

$\begin{array}{llll}10.8 & 8.8 & 4.3 & 2.9\end{array}$

5. consultatiebureau voor $\begin{array}{llll}86.0 & 89.1 & 55.9 & 50.1\end{array}$ geboorteregeling en sexualiteitsvragen

6. chirurgische poli $\begin{array}{llll}24.7 & 10.2 & 12.2 & 5.1\end{array}$ Overige:

$\begin{array}{ll}\text { GEBRUIK } & \text { (mogelijk) NUT } \\ \text { percentage } & \text { percentage } \\ \text { "Geen" } & \text { "Geen" }\end{array}$

D. t.a.v. therapeutisch gesprek

$\mathrm{KS}$ GS

KS GS

1. algemeen matschappelijk werk $\begin{array}{llll}36.5 & 38.1 & 21.5 & 18.4\end{array}$

2. ambulante geestel1jke gezondheidszorg

$\begin{array}{llll}32.3 & 3.1 & 16.1 & 17.5\end{array}$

3. psychiater

$\begin{array}{llll}51.6 & 40.6 & 25.8 & 21.1\end{array}$

4. psycholoog

$\begin{array}{llll}71.0 & 72.2 & 17.2 & 21.0\end{array}$

Overige: 
E. t.a.v. advies

1. diëtiste

2. schooladviesdienst

3. consultatiebureau voor geboorteregeling en sexualiteitsvragen

4. algemeen maatschappelijk werk

5. bureau voor medische sportkeuring

6. bedrijfsgeneeskundige dienst

Overige:

$\begin{array}{ll}\text { GEBRUIK } & \text { (mogelijk) NUT } \\ \text { percentage } & \text { percentage } \\ \text { "Geen" } & \text { "Geen" }\end{array}$

KS GS KS GS

$\begin{array}{llll}35.4 & 39.1 & 16.2 & 18.1\end{array}$

$71.0 \quad 74.0 \quad 30.1 \quad 27.4$

$89.2 \quad 89.9 \quad 55.5 \quad 51.1$

$\begin{array}{llll}40.8 & 38.5 & 19.4 & 20.8\end{array}$

$81.7 \quad 76.9 \quad 43.0 \quad 54.5$

$\begin{array}{llll}55.9 & 62.2 & 26.9 & 25.4\end{array}$
F. t.a.v. begelelding van

KS GS KS GS patiẻnten

1. algemeen matschappelijk $\begin{array}{llll}34.4 & 37.3 & 16.3 & 16.3\end{array}$ werk

2. ambulante geestelijke

GEBRUIK

Percentage

"Geen"

$\begin{array}{llll}38.7 & 40.4 & 16.2 & 18.6\end{array}$ gezondheidszorg

3. consultatatiebureau voor alcoholisme en drugs (mogelijk) NUT Percentage "Geen" 
4. schoolmaat schappelijk werk

5. klinisch psychiater

6. pastor

Overige:

$\begin{array}{llll}87.1 & 88.1 & 51.6 & 43.7 \\ 61.3 & 49.1 & 30.1 & 22.0 \\ 71.0 & 70.5 & 29.0 & 29.6\end{array}$

$\begin{array}{llll}71.0 & 70.5 & 29.0 & 29.6\end{array}$

$\begin{array}{ll}\text { GEBRUIK } & \begin{array}{l}\text { (mogelijk) NUT } \\ \text { Percentage } \\ \text { "Geen" }\end{array} \\ \text { "Geen" } & \begin{array}{l}\text { "Gentage } \\ \text { KS GS }\end{array} \text { KS } \quad \text { GS }\end{array}$

G. t.a.v. Preventie

1. consultatiebureau voor $\begin{array}{llll}36.5 & 42.8 & 9.7 & 16.3\end{array}$ T.B.C.-bestrijding

2. ziekenhuis labora torium $\begin{array}{llll}34.4 & 27.8 & 20.4 & 14.5\end{array}$ voor huisartsen

3. E.C.G. dienst $\begin{array}{llll}70.0 & 72.7 & 23.6 & 25.4\end{array}$

4. G.G.\& G.D./districts$\begin{array}{llll}77.4 & 70.8 & 37.6 & 38.7\end{array}$ geneeskund $1 \mathrm{ge}$ dienst

5. bedrijtsgeneeskundige dienst

$\begin{array}{llll}72.0 & 70.2 & 29.0 & 30.0\end{array}$

6. consultatiebureau voor zulgelingenzorg

7. schoolartsenzorg $\begin{array}{llll}31.1 & 34.2 & 12.9 & 18.0\end{array}$

8. consultatiebureau voor geboorteregeling en sexualiteltsvragen

$\begin{array}{llll}18.7 & 18.0 & 11.8 & 8.6\end{array}$ overige: 
20. Wilt $u$, door telkens een cijfer te omcirkelen, aangeven op welk niveau - diagnostisch en therapeutisch - een huisarts moet kunnen functioneren met betrekking tot aandoeningen, waarbij u ervan uit mag gaan, dat er geen acute of dringende indicaties bestaan voor spoedopname of spoedverwijzing.

A. Diagnostisch niveau

KS GS

(percentage

"mee eens")

92.596 .7

1. Een huisarts behoort zelfstandig de diagnose cholelithiasis te kunnen stellen.

2. Een huisarts moet, eventueel m.b.v. 38.7 32.7 een E.C.G.-dienst, zelf cardiale ritmestoornissen kunnen differentiëren.

3. Een huisarts dient ingeval van 38.7 32.7 fertiliteitsklachten zelf een onderzoek naar de oorzaken bij beide partners in te kunnen stellen met behulp van gynaecologisch onderzoek, B.T.C., Sims-Hühner-test en semenanalyse.

4. Een huisarts behoort met behulp van $32.2 \quad 30.6$ gedetallleerd onderzoek ontwikkelingsstoornissen bij kinderen te kunnen vaststellen.

5. Een huisarts dient E.C.G.'s te kunnen 20.4 26.3 beoordelen.

6. Een huisarts moet audiogrammen kunnen beoordelen.

7. Een huisarts moet oogfundusonderzoek kunnen beoordelen.
$48.3 \quad 46.5$

$61.3 \quad 70.3$ 
8. Een hulsarts moet d.m.v. een punctie een haemarthros kunnen vaststellen.

9. Een hulsarts dient in staat te zijn $74.2 \quad 68.5$ een verhoogde oogboldruk te meten.

B. Therapeutisch niveau

KS

GS

(percentage

"mee eens")

$43.0 \quad 42.5$

$53.7 \quad 62.8$

93.593 .5

3. De hulsarts dient een patiënt met een acute urineretentie als gevolg van een prostaat-hypertrofie zelf te kunnen catheteriseren.

4. Het aanmeten van een bril voor presbyopie of lichte myopie moet de huisarts zelf kunnen doen.

5. De huisarts behoort een patiënt met een atopie zelf te kunnen desensibiliseren.

6. Gevallen van lichte tot matig ernstige rheumatoide arthritis moeten door de huisarts zelf behandeld kunnen worden.

7. Een huisarts dient een patiënt met een ulcus duodeni zelf te kunnen behandelen.

\section{$26.9 \quad 26.4$}

$64.5 \quad 52.5$

$82.8 \quad 80.3$

$95.7 \quad 93.1$ 
8. De behandeling van een patiënt in $50.5 \quad 55.4$ een acute psychische crisistoestand dient door de huisarts gedaan te kunnen worden.

9. De huisarts dient een gravida met $75.3 \quad 75.2$ een lichte zwangerschapstoxicose zelf te kunnen behandelen.

21. Thans volgen er een aantal uitspraken over de verhouding arts-patiënt en over psycho-sociale klachten. Wilt u door omcirkeling van een cijfer aangeven in hoeverre $u$ het met de uitspraak eens of oneens bent?

1. Een huisarts moet altijd beschikbaar

KS

GS

(percentage

"mee eens") zijn voor zijn patiënten.

2. Als de huisarts een patiënt medicijnen $86.0 \quad 85.6$ voorschrijft, dan dient hij de werking hiervan aan hem uit te leggen.

3. Patiënten moeten tegen hun huisarts 19.3 28.8 op kunnen zien.

4. Gezien de psychische aard van bepaalde 87.9 87.8 klachten warmee patiënten $b i j$ hun huisarts komen, dient deze zich ook op dit terrein te bekwamen.

5. Huisartsen zouden hun patiënten meer 74.2 80.8 uitleg over hun ziektes moeten geven.

6. Met een afsprakenspreekuur is een 60.2 61.6 huisarts voldoende beschikbaar voor zijn patiënten. 
7. Het hoort tot de taak van de huisarts zijn patiënt met psycho-soclale klachten de weg te wijzen in de maatschappelijke dienstverlening.

8. Klachten van patiënten hebben vaak $93.5 \quad 89.2$ meer te betekenen dan oppervlakkig lijkt.

9. Een succesvolle behandeling hangt in 89.194 .1 hoge mate af van het feit of de patiënt er het nut en de werking van inziet.

10. De huisarts behoort een natuurlijk $48.4 \quad 46.2$ overwicht te hebben over zijn patiënten.

11. Een huisarts zou patiënten meer moge26.9 41.6 lijkheden moeten geven om op afspraak buiten het spreekuur bif hem langs te komen.

12. Het verlenen van hulp bij psycho-sociale 17.2 21.0 problemen gat de competentie van de buren te boven.

13. Het contact van hulisarts en patiënt is een contact van gelijkwaardigen.

14. Vakken als psychologie en soclologie moeten een vaste plaats krijgen in de $67.9 \quad 70.9$ opleiding tot arts. 
22. Thans volgt er een vraag naar uw mening over een aantal aspecten van uw werk. U wordt verzocht gebruik te maken van de schaalwaarden $1-5$ zoals naast het criterium vermeld staan.

Mijn werk als huisarts is:

1. Fascinerend

2. Routinematig

3. Bevredigend

4. Vervelend

5. Goed

6. Creatief

7. Waardering schenkend

8. Gejaagd

9. Aangenaam

10. Nuttig

11. Vermoeiend

12. Gezond

13. Uitdagend

14. Veeleisend

15. Frustrerend

16. Eenvoudig

17. Uitzichtioos

18. Vruchtbaar
KS

(percentage

"mee eens")

78.4

37.6

84.9

3.2

63.4

53.7

63.4

48.3

76.3

80.7

66.6

29.0

76.3

84.9

28.9

9.6

7.5

65.6

74.8

37.6

87.6

6.0

65.0

52.3

65.0

53.0

74.7

85.9

69.7

23.3

74.5

87.6

29.9

5.2

4.5

71.0

De Waarneming

GROTE STEEKPROEF

(percentage "eens")

23. Wilt $u$ aangeven in hoeverre $u$ het eens of oneens bent met de volgende uitspraken over het waarnemen.

- Meestal voel ik me tijdens de waarneming erg nerveus. 
- Tijdens de waarneming sta $\mathrm{ik}$ erg onder druk

- Na afloop van de warneming ben ik geestelijk en lichamelijk volledig uitgeput

- Waarnenen is buitengewoon vermoelend

24. Accepteert $u$ het dat de L.H.V. zich actiever c.q. regulerender opstelt dan het geven van (zwaarwegende) adviezen, indien misstanden in waarnemingsregelingen worden geconstateerd?

$$
\begin{array}{llr}
\text { 1. Ja } & 82.3 \\
\text { 2. Geen mening } & 9.5 \\
\text { 3. } & \text { Nee } & 8.2
\end{array}
$$

Nascholing

25. Wilt u uw mening geven t.a.v. de volgende uitspraak.

$$
\text { "eens" }
$$

Een huisarts moet verplicht worden om één keer per jaar een georganiseerde cursorische nascholing te volgen.

26. De duur van een cursorische nascholing dient een aaneengesloten periode te bedragen van:

$$
\begin{array}{lr}
\text { 1. minder dan } 2 \text { dagen } & 12.1 \\
\text { 2. } 2 \text { dagen } & 24.4 \\
\text { 3. } 3 \text { tot } 5 \text { dagen } & 50.3 \\
\text { 4. meer dan } 5 \text { dagen } & 5.9
\end{array}
$$


27. Hoe moet naar uw mening een verplichte nascholing mogelijk gemaakt worden?

$$
\text { "eens" }
$$

1. Door een waarnemingsregeling 76.2 binnen de eigen warnemingsgroep.

2. Door een financiële tegemoetkoming 10.4 in de kosten van een door de huisarts zelf te zoeken waarnemer.

3. Centraal door het bureau warnemingen van de L.H.V.

Toetsing

28. Wilt u t.a.v. de volgende uitspraken uw mening geven?

"eens"

- Iedere vorm van toetsing zal een

facultatief karakter moeten hebben.

60.3

- De resultaten van een periodieke toetsing moeten als voorwaarde gelden voor de registratie in het huisartsregister.

- De toetsing dient zich voornamelijk op het medisch handelen van de huisarts te richten. $61 \cdot 1$

- De arts-patiënt-relatie moet het belangrijkste aspect van de toetsing zijn.

- De praktijkorganisatie dient het belangrijkste aspect van de toetsing te zijn. 
Medicatiebewaking

29. Wilt u uw menlng geven t.a.v. de volgende uitspraak:

$$
\text { "eens" }
$$

Ter voorkoming van ongewenste interactie en overmatig gebruik van geneesmiddelen is een formeel geregelde vorm van medicatie-bewaking noodzakelijk.

30. Een formeel geregelde vorm van medicatiebewaking dient opgedragen te worden aan: (slechts één antwoord aankruisen s.v.p.)

$$
\begin{aligned}
& \text { "eens" } \\
& \text { 1. de huisarts } \\
& 32.4 \\
& \text { 2. de apotheker } \\
& 56.0 \\
& \text { 3. de inspectie van } \\
& \text { de volksgezondheid } \\
& 8.0
\end{aligned}
$$

Prescriptie

31. Wilt u uw mening geven t.a.v. de volgende uitspraken?

$$
\text { "eens" }
$$

- De Regeling en Klapper dient als verplichte norm t.a.v. de prescriptie te worden ingevoerd.

- Een geformaliseerd overleg tussen huisarts en apotheker is noodzakelijk on de kwaliteit van de prescriptie te bewaken. 
Vestigingsbeleid

32. Denkt u dat, indien de L.H.V. zelf geen regulering van vestigingsbeleid tot stand brengt, de overheid deze zaken ter hand zal nemen?

$$
\begin{array}{ll}
\text { 1. ja } & 75.5 \\
\text { 2. geen mening } & 12.8 \\
\text { 3. nee } & 11.7
\end{array}
$$

33. Accepteert $u$ een verlaging van de rekennormpraktijk (thans 2600) tot 2000?

$$
\begin{array}{ll}
\text { 1. ja } & 54.4 \\
\text { 2. geen mening } & 14.5 \\
\text { 3. nee } & 31.2
\end{array}
$$

34. Accepteert $u$ een maximering van de praktijkgrootte in verband met een vestigingsbeleid? (Maximeren betekent hier dat de huisarts niet meer gehonoreerd wordt boven de rekennormpraktijk $+25 \%$ !)

$$
\begin{array}{lr}
\text { 1. ja } & 69.7 \\
\text { 2. geen mening } & 7.2 \\
\text { 3. nee } & 23.1
\end{array}
$$

35. Accepteert u een maximum-percentage van $90 \%$ van de bruto praktijkopbrengst in één jaar bij overdracht als goodwillbetaling?

$$
\begin{array}{ll}
\text { 1. ja } & 76.7 \\
\text { 2. geen mening } & 10.3 \\
\text { 3. nee } & 13.0
\end{array}
$$


36. Acht u een verplicht overdragen van nevenfuncties, en dus het openbaarmaken van verdiensten daaruit, een aanvaardbaar instrument in het kader van een vestigingsbeleid?

$$
\begin{array}{ll}
\text { 1. ja } & 35.5 \\
\text { 2. geen mening } & 22.9 \\
\text { 3. nee } & 41.6
\end{array}
$$


BIJLAGE 2: VERSCHILLEN IN TESTWAARNEMINGEN TUSSEN OBSERVATOREN ONDERLING EN IN VERGELIJKING MET DE ONDERZOEKER-OBSERVATOR, WEERGEGEVEN MET BEHULP VAN DE BIJBEHORENDE WAARDEN VAN $X^{2}$

\section{test 1 test 2 test 3 test 4 \\ freq. tijd freq. tijd freq. tijd freq. tijd}

\begin{tabular}{|c|c|c|c|c|c|c|c|c|}
\hline Diagnostiek & 0.71 & 0.41 & 0.28 & 0.05 & 0.63 & 0.43 & 0.57 & 0.33 \\
\hline Therapie & $2.68 *$ & $2.89 *$ & 0.40 & 0.31 & 1.78 & 0.80 & 1.68 & 1.43 \\
\hline Preventie & 0.87 & 0.84 & - & - & - & - & 0.00 & 0.63 \\
\hline Begeleiding & - & - & 0.01 & 0.75 & 0.01 & 0.46 & 0.00 & 0.14 \\
\hline Verwijzing & - & - & 0.01 & 1.37 & 0.00 & 0.00 & - & - \\
\hline $\begin{array}{l}\text { Vrijheids- } \\
\text { graden }\end{array}$ & 7 & 7 & 6 & 6 & 7 & 7 & 8 & 8 \\
\hline $\begin{array}{l}\text { Aantal con- } \\
\text { sulten }\end{array}$ & 5 & 1 & 5 & I & 6 & 1 & 5 & $/$ \\
\hline Totale tijd & 1 & $\begin{array}{l}43 \\
\min .\end{array}$ & / & $\begin{array}{l}37 \\
\text { min. }\end{array}$ & / & $\begin{array}{l}30 \\
\text { min. }\end{array}$ & 1 & $\begin{array}{l}48 \\
\text { min. }\end{array}$ \\
\hline
\end{tabular}

(De waarden met * zijn significant op .05 niveau). 
BIJLAGE 3: OBSERVATIE-CATEGORIEEN

FUNCTIE

Diagnostiek

$22.1 \%$

THERAPIE

$15.1 \%$

Preventie
TIJD IN MIN. PERC.

$7747 \quad 8.9$

$\begin{array}{ll}9397 & 10.8\end{array}$

anderzoek

onderzoek:

zelf

978

1.1

Laboratoriumonderzoek:

uitbesteed

558

0.6

Diagnose:

uitbesteed

565

0.7

\section{5}

MEDICATIE

Advies

Gesprek

Handeling

Partus
5865

2552

2488

2175

56

13136
6.7

2.9

2.9

2.5

0.2

Geboorteregeling

Perinatale zorg

G.V.O.

Vacclnatie

Perlodiek genees-

kundig onderzoek

Surveillance

risicopatiënten

2282

920

108

235

603

369
2.6

1.1

0.1

0.3

0.7

0.4 


\begin{tabular}{|c|c|c|c|}
\hline Begeleiding & $\begin{array}{l}\text { Curatieve zorg } \\
\text { chronisch zieken } \\
\text { Follow-up } \\
\text { Informatie- } \\
\text { verstrekken }\end{array}$ & $\begin{array}{l}4077 \\
951 \\
236\end{array}$ & $\begin{array}{l}4.7 \\
1.1 \\
0.3\end{array}$ \\
\hline $6.1 \%$ & & 5264 & \\
\hline Verwijzing & $\begin{array}{l}\text { Binnen gezondheids- } \\
\text { zorg incl. consult } \\
\text { vragen/geven } \\
\text { Buiten gezondheids- } \\
\text { zorg incl. inlich- } \\
\text { tingen vragen/geven }\end{array}$ & 2207 & 2.5 \\
\hline $2.8 \%$ & & 2504 & \\
\hline Condities & $\begin{array}{l}\text { Praktijkorganisatie } \\
\text { Registratie en } \\
\text { administratie } \\
\text { Onderwijsgeven } \\
\text { Bijscholing } \\
\text { Samenwerking }\end{array}$ & $\begin{array}{r}4652 \\
3589 \\
452 \\
1356 \\
2332\end{array}$ & $\begin{array}{l}4.1 \\
0.5 \\
1.6 \\
2.7\end{array}$ \\
\hline $14.2 \%$ & & 12381 & \\
\hline
\end{tabular}

$65.5 \% \quad 57047$ sub-totaal


OVERIGE

ACT IVITEITEN

Activiteiten

als arts

$3,5 \%$
TIJD IN MIN. PERC.

$\begin{array}{lrr}\text { Keuringen } & 1294 & 1.5 \\ \text { Medisch adviseur } & 108 & 0.1 \\ \text { Medische indicatie } & 64 & 0.1 \\ \text { stellen } & & \\ \text { Groepsbegeleiding } & 1069 & 1.2 \\ \text { Bestuursactiviteiten } & 64 & 0.1 \\ \text { Overige } & 388 & 0.5\end{array}$

2987
Apothekerswerk

Sociaal contact

Telefoon

Reistijd

Privê

$31.0 \%$
344

2571

5021

9964

9205

27105
$34.5 \%$

30092 sub-totaal

$100 \%$

87139

TOTAAL

$(= \pm 1452$ uur $)$ 
$$
\text { . }
$$ 
BIJLAGE 4: CORRELATIEMATRIX (PEARSON $r$ ) VAN ALLE VARIABELEN DIE IN DE ANALYSE ZI.JN GEBRUIKT.

$\begin{array}{llllll}1 & 2 & 3 & 4 & 5 & 6\end{array}$

Relatieve tijd

besteed aan

1. diagnostiek

2. therapie

3. preventie

4. begeleiding

5. condities

6. privê

7. proportie verwijzingen

$$
\begin{array}{lllllll}
-- & & & & & \\
+.45 & -- & & & & \\
+.02 & +.02 & -. & & & \\
-.18 & -.15 & -.15 & -- & & \\
-.37 & -.26 & -.24 & -.21 & -- & \\
-.44 & -.42 & +.03 & -.01 & +.03 & - \\
-.08 & -.12 & -.29 & -.02 & +.17 & -.13 \\
-.17 & -.09 & +.15 & +.17 & -.08 & +.15 \\
+.51 & +.51 & +.07 & -.04 & -.33 & -.18 \\
-.14 & +.10 & -.08 & -.01 & +.15 & -.01 \\
-.04 & +.02 & +.16 & -.09 & -.11 & +.24 \\
-.08 & -.02 & -.01 & -.07 & +.35 & -.05 \\
-.33 & -.25 & +.14 & +.01 & +.19 & +.25 \\
+.27 & +.04 & -.10 & +.01 & +.01 & -.22 \\
+.17 & +.22 & -.02 & -.04 & -.15 & -.25
\end{array}
$$

8. praktijkervaring

9. gemiddeld patiëntenaanbod

10. taakbreedte

11. niveau van diag. en ther.

12. bereidheid tot samenwerking

13. beschikbare $t \perp j d$ en voorzleningen

14. gebruik van voorzieningen

15. urbanisatiegraad gemeente

16. ratio kinderen

< 14 jaar

17. ratio $\mathrm{zf}$-patiënten

18. praktijkomvang

19. praktijkvorm

20. apotheekhoudend

$-.1$

$+.08$

$+.08$

$+.09$

$$
-.01
$$

$+.18$

$+.14$

$-.05$

$-.1$

$+.16$

$+.10$

$-.29$
$+.09$

$-.08$

$+.01$

$+.07$

$-.03$

$-.01$

$+.20$

$+.06$

$+.22$

$-.40$

$+.06$

$+.22$
$+.30+.16$ 


\section{$\begin{array}{llllllll}7 & 8 & 9 & 10 & 11 & 12 & 13 & 14\end{array}$}

7. proportie ver-

wijzingen

8. praktijkervaring

9. gemiddeld patiëntenaanbod $-.13-.01-$ -

10. taakbreedte $-.01+.02-.05-$

11. niveau van diag. en ther. $-.24+.07-.04+.16--$

12. bereidheid tot samenwerking $+.17-.09+.05+.03+.02--$

13. beschikbare tijd en voorzieningen $-.12+.21-.17+.13+.02-.03--$

14. gebruik van voorzieningen $+.12+.02+.25+.05-.01+.18-.07--$

15. urbanisatiegraad gemeente $+.19-.13+.20-.11-.08+.01-.22+.33$ 16. ratio kinderen $<\quad 14$ jaar $-.22+.03-.03+.07+.09+.21-.15-.26$

17. ratio zf patiënten $\quad+.05-.10+.04-.10-.01-.01-.18+.01$ 18. praktijkomvang $+.06+.25+.25-.08-.20+.02+.07+.01$ 19. praktijkvorm $-.05-.16+.04-.08-.01+.42-.01+.02$ 20. apotheekhoudend

$$
-.15+.18-.27+.17+.06+.20+.20-.11
$$

15. urbanisatiegraad gemeente

16. ratio kinderen $<14$ jaar

17. ratio zf-patiën-

\section{ten}

18. praktijkomvang

19. praktijkvorm

20. apotheekhoudend

$$
-.32--
$$

$+.03-.03--$

$-.01+.16+.10--$

$+.09+.10-.06-.03--$

$-.55+.32-.09-.07+.08--$ 
BIJLAGE 5: OVERZICHT VAN VERSCHILLEN IN RELATIEVE TIJDBESTEDING

$\begin{array}{lll}\text { praktijk- } & \text { taak- } & \text { bereidheid } \\ \text { ervaring } & \text { breedte } & \text { tot samen- } \\ & & \text { werking }\end{array}$

$\leqslant 9 j r .>9 j r$ smal breed weinig veel

1. Diagnostiek

2. Theraple

3. Preventie

4. Begeleiding

5. Condities

6. Prive

7. Verwijzingen
23.3

21.4

14.9

14.7

5.4

5.1

$\frac{5.3}{1.4 .3}$

$\frac{6.7}{14.2}$

10.5

11.0

10.4
23.6

14.4

5.5

6.0

13.3

21.5

15.1

5.1

6.0

10.2

9.6

14.8

11.0

9.7

22.122 .6

$14.6 \quad 14.8$

$5.8 \quad 5.0$

$6.3 \quad 5.9$

$\frac{11.5}{11.6} \quad \frac{15.9}{9.9}$

8.610 .5

beschikbare tijd en voorzieningen weinig veel

1. Diagnostiek

2. Therapie

3. Preventie

4. Begeleiding

5. Condities

6. Prive

7. Verwifzingen
23.8

$\frac{16.0}{4.8}$

6.3

12.0

9.8

10.2
21.5

$\frac{14.0}{5.6}$

5.9

15.7

11.3

9.7 niveau van diagnostiek en therapie

laag

hoog

22.1

14.7

4.0

6.5

15.0

$\frac{8.7}{10.2}$
22.5

14.7

5.5

5.8

13.8

$\frac{12.0}{9.6}$ 
gebruik van voorzieningen weinig

veel

$\frac{19 \cdot 3}{14.5}$

5.8

5.8

14.7

12.4

8.9

\begin{tabular}{r}
24.3 \\
\hline 14.9 \\
5.0 \\
6.2 \\
13.9 \\
9.6 \\
10.4
\end{tabular}

gemiddeld aantal patiënten per uur

$<5,5$

$\geqslant 5,5$

1. Diagnostiek

2. Therapie

3. Preventie

4. Begeleiding

5. Condities

6. Prive

7. Verwijzingen

$\frac{\frac{18.9}{12.6}}{4.7}$

$\frac{\frac{26.2}{17.1}}{5.6}$

6.3

5.7

$\frac{16.6}{12.3}$

$\frac{11.6}{\frac{8.9}{8.8}}$

N.B.: In de cellen van de regels 1 tot en met 6 staan de gemiddelde percentages tijd die besteed zijn aan de betreffende functie gedurende de observatieperiode; in regel 7 staan de gemiddelde proporties verwijzingen per 100 consulten gedurende diezelfde periode.

De onderstreepte gemiddelde waarden verschillen significant op .05 niveau. 


\section{CURRICULUM VITAE}

Op 22 juni 1942 ben ik geboren te Venlo en mijn schooljaren heb ik doorgeracht in Maasbree.

Het gymnasium $B-d i p l o m a$ heb $i k$ behaald aan het Klein-Seminarle Rolduc te Kerkrade in juni 1961. Na twee jaar fllosofie in Heerlen en drie jaar theologie in Roermond te hebben gestudeerd, ben ik in 1966 begonnen aan de studie Westerse Sociologie aan de Katholieke Universiteit te Nijmegen. Hierin behaalde ik het doctoraal examen in april 1972 met als hoofdvakken Methoden en technieken van Onderzoek en Theoretische Sociologie.

In mei 1972 kreeg ik mijn eerste aanstelling als staf-medewerker bij het bureau van de Raadsadviseur voor Lange Termijn Planning, bij het Ministerie van Volksgezondheid en Milieuhygiëne te Leidschendam.

In september 1975 volgde mijn verbintenis met de Rijksuniversiteit Limburg, waar ik tot op heden werkzaam ben als lid van de capaciteitsgroep Medische Sociologie. 